\title{
The Role of Neurokinin B in the Regulation of the Preovulatory LH Surge in Ewes
}

Katrina L. Porter

West Virginia University

Follow this and additional works at: https://researchrepository.wvu.edu/etd

\section{Recommended Citation}

Porter, Katrina L., "The Role of Neurokinin B in the Regulation of the Preovulatory LH Surge in Ewes" (2013). Graduate Theses, Dissertations, and Problem Reports. 622.

https://researchrepository.wvu.edu/etd/622

This Dissertation is protected by copyright and/or related rights. It has been brought to you by the The Research Repository @ WVU with permission from the rights-holder(s). You are free to use this Dissertation in any way that is permitted by the copyright and related rights legislation that applies to your use. For other uses you must obtain permission from the rights-holder(s) directly, unless additional rights are indicated by a Creative Commons license in the record and/ or on the work itself. This Dissertation has been accepted for inclusion in WVU Graduate Theses, Dissertations, and Problem Reports collection by an authorized administrator of The Research Repository @ WVU.

For more information, please contact researchrepository@mail.wvu.edu. 


\title{
The Role of Neurokinin B in the Regulation of the Preovulatory LH Surge in Ewes
}

\author{
Katrina L. Porter \\ Dissertation submitted to the School of Medicine at West Virginia University \\ in partial fulfillment of the requirements for the degree of \\ Doctor of Philosophy \\ in \\ Cellular and Integrative Physiology
}

Robert L. Goodman, PhD; Mentor

Stanley M. Hileman, PhD

Heather J. Billings, PhD

Steven L. Hardy, PhD

Adrienne Salm, $\mathrm{PhD}$

Department of Physiology and Pharmacology

Morgantown, WV

2013

Key words: luteinizing hormone, neurokinin B, kisspeptin, NK3R, sheep, retrochiasmatic area Copyright 2013 Katrina L. Porter 


\section{ABSTRACT \\ The Role of Neurokinin B in the Regulation of the Preovulatory LH Surge in Ewes Katrina L. Porter}

Hypothalamic input is vital to the regulation of reproductive function. Gonadotropin-releasing hormone $(\mathrm{GnRH})$ is secreted by hypothalamic GnRH neurons into the hypophysial portal circulation. When GnRH reaches the anterior pituitary, it stimulates gonadotropes to secrete luteinizing hormone (LH) into the systemic circulation, ultimately leading to ovulation. GnRH/LH secretion occurs in two different patterns: pulsatile or surge. Pulsatile GnRH release is governed by estradiol $\left(\mathrm{E}_{2}\right)$ negative feedback while surge release is the result of $E_{2}$ positive feedback. However, GnRH neurons lack the alpha isoform of the estrogen receptor, indicating that $\mathrm{E}_{2}$ feedback on $\mathrm{GnRH}$ release is indirect. Other hypothalamic neurons that express $\mathrm{ER} \alpha$ have been identified as possible intermediates in this $\mathrm{E}_{2}$ feedback pathway, including those containing neurokinin $\mathrm{B}(\mathrm{NKB})$ and kisspeptin.

Kisspeptin has been identified as a potent stimulator of LH secretion in a variety of species. GnRH neurons express the kisspeptin receptor (Kiss1r), indicating that kisspeptin can directly stimulate GnRH secretion. Two anatomically separate populations have been identified in the hypothalamus: one in the arcuate nucleus (ARC) and the other in the preoptic area (POA). Furthermore, ARC kisspeptin neurons have been found to colocalize two other neuropeptides as well: NKB and dynorphin A (DYN). Thus, these neurons were assigned the acronym KNDy neurons. The specific role of these two kisspeptincontaining populations in $\mathrm{GnRH} / \mathrm{LH}$ regulation is unclear. Therefore we examined the degree to which each of these populations were activated, using cFos as an index of activation, during positive $\mathrm{E}_{2}$ feedback (surge) or following $\mathrm{E}_{2}$ withdraw (i.e. after ovariectomy). We found that both populations exhibited increased activation during the $\mathrm{GnRH} / \mathrm{LH}$ surge, indicating that both are involved in $\mathrm{E}_{2}$-positive feedback. Only the ARC kisspeptin neurons showed increased activation after $\mathrm{E}_{2}$ withdrawal, indicating that only the KNDy neurons are playing a role in $\mathrm{E}_{2}$-negative feedback control of GnRH release.

NKB neurons have been shown to consistently stimulate GnRH/LH secretion in non-rodent species. Since KNDy neurons express receptors for NKB (NK3R), the current proposed model suggests 
that NKB acts in a paracrine or autocrine fashion to stimulate kisspeptin release from KNDy neurons which then acts directly to initiate a pulse of GnRH. Dynorphin from KNDy neurons then acts to terminate kisspeptin release and end the pulse of GnRH release. However, high levels of neurokinin-3receptor (NK3R) are found outside of KNDy neurons in the ovine POA, ARC, retrochiasmatic area (RCh), and paraventricular nucleus (PVN). We first examined whether NKB or senktide, an NK3R agonist, would alter LH secretion if placed within each of these areas. While NKB, in any of those areas, had no effect on LH secretion, senktide placed in either the RCh or POA stimulated a surge-like secretion of LH, suggesting that NK3R activation in these areas may play a role in the GnRH/LH surge. Thus, we subsequently placed an NK3R antagonist in the RCh or POA during an $\mathrm{E}_{2}$-induced LH surge and found that blocking NK3R in the RCh, but not the POA, significantly suppressed LH surge amplitude. These results suggest that NK3R activation in the RCh is essential for the full LH surge.

As mentioned above, one current model suggests that NKB exerts its actions via kisspeptin output to GnRH neurons; however, this has not been examined in ewes. We first assessed activation of the ARC and POA populations of kisspeptin neurons following senktide treatment in either the RCh or POA. We found that senktide in either area significantly increased ARC kisspeptin neuron activation but did not alter activity of POA kisspeptin neurons. To further test the model, we gave a Kiss1r-antagonist (via intracerebroventricular infusion) during senktide treatment to see if blocking kisspeptin receptors would ameliorate senktide-induced surge-like LH secretion. This experiment yielded inconsistent results, with the increase in LH blocked in some ewes by Kiss1r antagonist infusion but not in others. Nonetheless, based on the activation data, we conclude that NK3R activation stimulates LH secretion via ARC kisspeptin neurons.

In conclusion, we have identified a role for NK3R-positive neurons in the $\mathrm{RCh}$ in regulating the LH surge in ewes. These data reveal the importance of the RCh in the LH surge, an area whose involvement in this process was previously unknown. 


\section{ACKNOWLEDGEMENTS}

To personally thank everyone that has contributed to my graduate education and research would be difficult, but I would like to take this opportunity to thank a few of the most influential individuals.

I was lucky enough to work with one of the best and most respected mentors that I have had the opportunity of meeting. Bob Goodman took me into his laboratory as a $3^{\text {rd }}$ year graduate student and gave me the opportunity to take on a great project, working at full-steam to make up for time lost in a previous laboratory. Thanks Bob for giving me that chance and letting me prove myself. I have learned much about teaching, mentoring, and writing from you over these few years, that I am confident will help me to become a great teacher and mentor as well. I have to thank Casey Nestor for suggesting that I check out Bob's laboratory — he told me I could not find a better mentor, and for once, he was right. Thanks Casey for all the entertaining stories and adventures we had. Thanks to Stan Hileman for also acting as a mentor to me. Your guidance and input on my research and plans helped me more than you know. I learned from you, also, how to time my 'injuries' best to get out of farm work. Thanks to Steve Hardy for serving on my committee as well as mentoring me in my teaching pursuits. Thanks especially for almost always remembering to cover my classes when I had to be out of town. Thank you to Heather Billings and Adrienne Salm for your time spent in serving as part of my committee, as well as for your contributions to our surgeries, experimental planning, and ICC advice. A special thanks to Miro Valent for all of your radioimmunoassay expertise and your kind words throughout my time here, and to Gail Nesselrod for your animal expertise and for all the help with work at the farm at all hours of the night and day. And thank you to all other member of the Goodman lab, both past and present, that I have had the pleasure of working with and getting to know. I would like to take this chance to also thank my mom, Sandy Sites, for raising me to always do the best I can and go as far as possible in my pursuits. Thanks for always being there for me through everything. I also want to thank my wife Kerri Porter for all the support through these $6+$ years of graduate school. You have seen me at my best and worst, but you were always there to offer support and laughter. Thanks for helping me believe I could make it through. Thanks also to my other two favorite people in the world - my kids, Adlei and Sullivan. You have taught me how to put 
others first, to teach with patience, and to enjoy the small things. Lastly, thanks to the rest of my family, friends, and colleagues who have supported me in various ways throughout my time here in graduate school. I appreciate you all. Thanks-Kati 


\section{TABLE OF CONTENTS}

The Role of Neurokinin B in the Regulation of the Preovulatory LH Surge in Ewes...................i

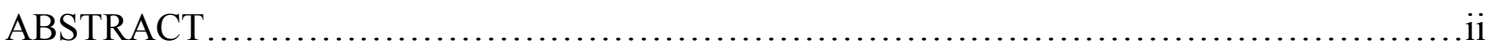

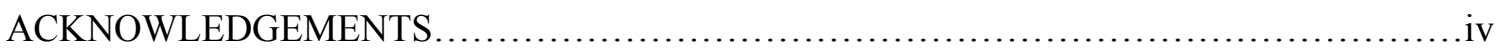

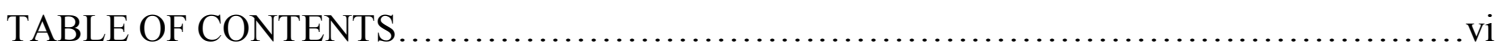

CHAPTER 1: KNDY NEURON INVOLVEMENT IN GRRH/LH SECRETION.....................1

THE HYPOTHALAMIC-PITUITARY-GONADAL AXIS ...............................

CONTROL OF GnRH/LH SECRETION PATTERNS ACROSS THE CYCLE.................. 3

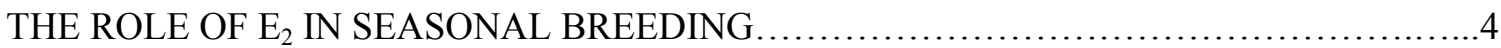

PATHWAY OF E FEEDBACK $\ldots \ldots \ldots \ldots \ldots \ldots \ldots \ldots \ldots \ldots \ldots \ldots \ldots \ldots \ldots \ldots \ldots \ldots \ldots \ldots \ldots \ldots \ldots \ldots \ldots \ldots \ldots \ldots \ldots \ldots \ldots \ldots \ldots \ldots \ldots$

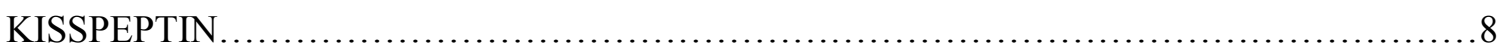

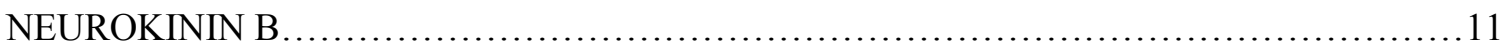

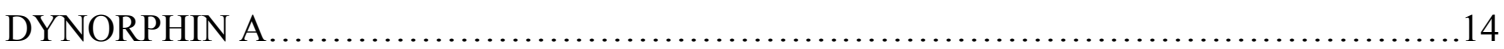

THE KNDy NEURAL NETWORK .................................................. 16

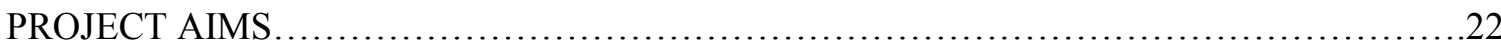

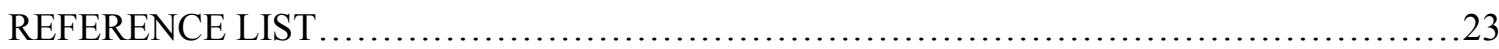

CHAPTER 2: KNDY (KISSPEPTIN/NEUROKININ B/DYNORPHIN) NEURONS ARE ACTIVATED DURING BOTH PULSATILE AND SURGE SECRETION OF LH

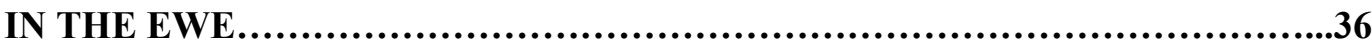

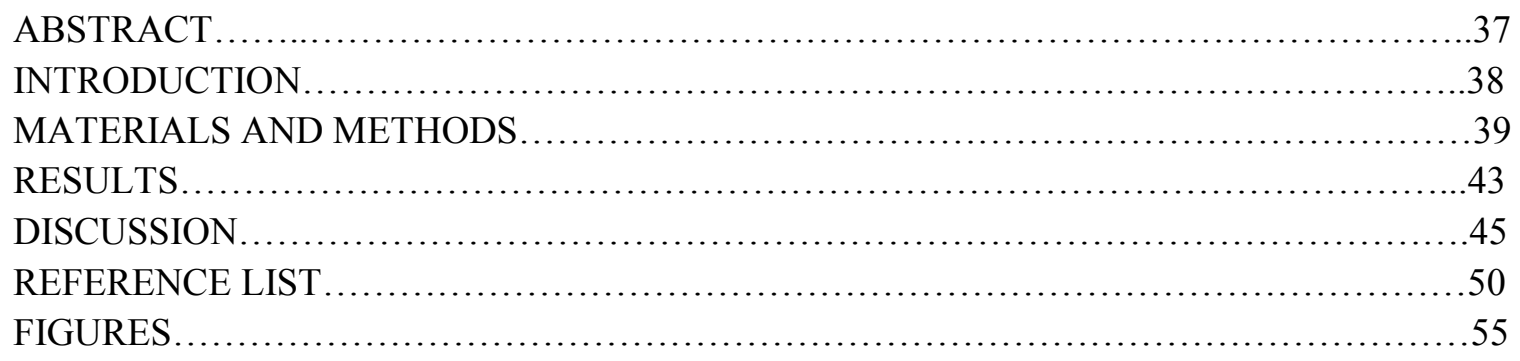

CHAPTER 3: NEUROKININ-3 RECEPTOR ACTIVATION IN THE RETROCHIASMATIC AREA IS ESSENTIAL FOR THE FULL PREOVULATORY LH SURGE IN

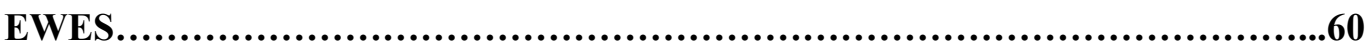

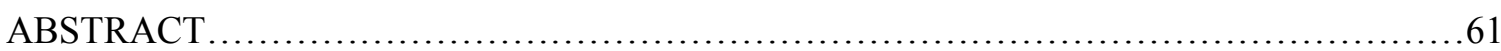

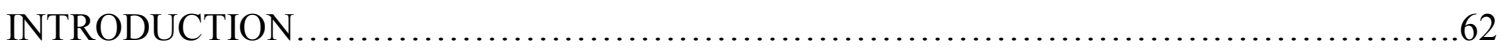

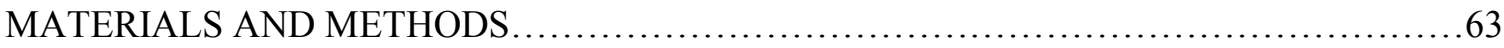

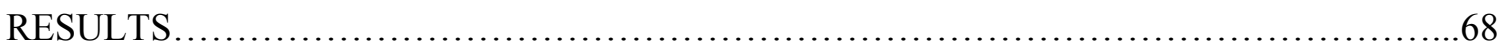

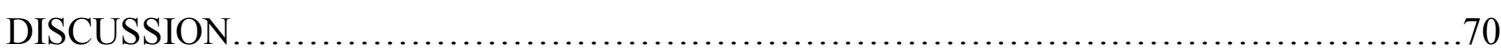

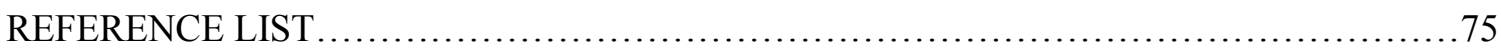

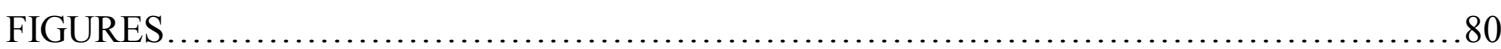


CHAPTER 4: SENKTIDE STIMULATES LH SECRETION VIA ARCUATE KISSPEPTIN

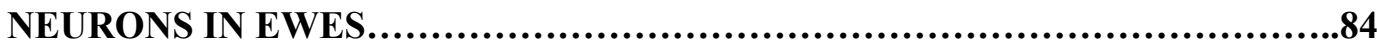

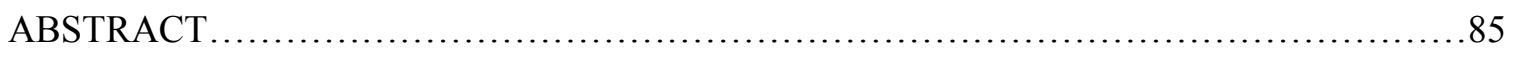

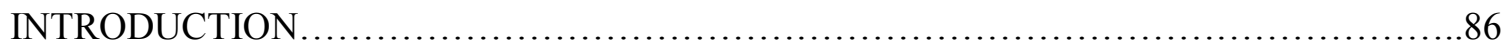

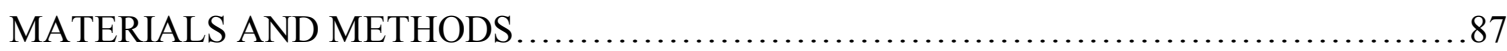

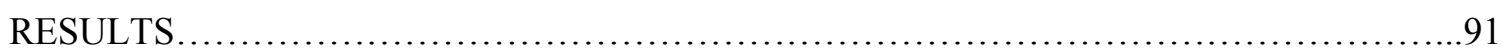

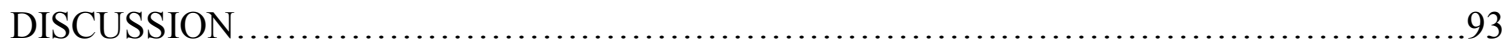

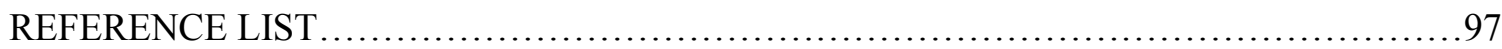

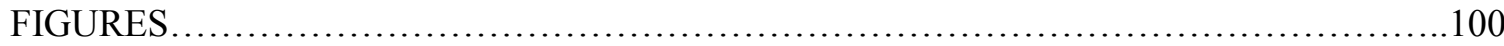

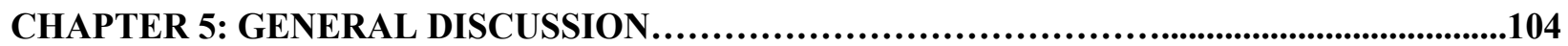

THE ROLE OF NKB IN LH PULSE GENERATION................................... 105

THE ROLE OF NKB IN THE LH SURGE..........................................107

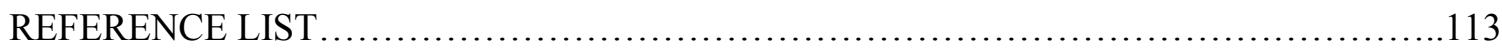

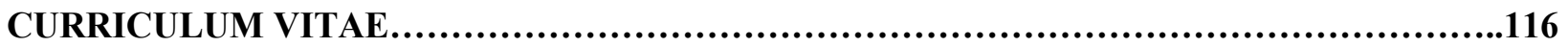




\section{CHAPTER 1}

LITERATURE REVIEW:

KNDY NEURON INVOLVEMENT IN GRRH/LH SECRETION 


\section{THE HYPOTHALAMIC-PITUITARY-GONADAL AXIS}

The estrous cycle is regulated by a complex feedback loop composed of hypothalamic neurons, the pituitary, and gonads. These components are collectively known as the hypothalamic-pituitarygonadal axis. As there are some differences across species, I will discuss these differences throughout this literature review. Neurons containing gonadotropin-releasing hormone $(\mathrm{GnRH})$ in the ewe are found throughout the preoptic area (POA) and mediobasal hypothalamus $(\mathrm{MBH})$, with nearly half of them terminating in the median eminence (ME) $(1 ; 2)$. When stimulated, these neurons synthesize and then secrete GnRH into the fenestrated capillaries of the hypophyseal portal system at the ME. GnRH, as its name implies, stimulates gonadotropes in the anterior pituitary to synthesize and secrete the two gonadotropins (so-named due to their role in stimulating the gonads), luteinizing hormone (LH) and follicle-stimulating hormone (FSH), into the systemic circulation.

\section{The Reproductive Cycle in Ewes and Primates}

The estrous cycle in ewes (3) and the menstrual cycle in primates (4) average 16-17 days and 28 days, respectively, in length and consists of two phases, follicular and luteal, which are named for the dominating ovarian structure during that period. Compared to primates, the relatively shorter estrous cycle in ewes is due to a shortened follicular phase. Depending on the phase of the estrous cycle, gonadotropins exert their action on follicles or the corpus luteum (CL).

LH concentrations slowly increase during the follicular phase and stimulate estradiol $\left(\mathrm{E}_{2}\right)$ secretion from the wave of developing follicles. As the follicular phase progresses, $E_{2}$ reaches a peak just before the preovulatory LH surge, a rapid bulk secretion of LH from the pituitary. The high concentration of LH at this time cause ovulation of the preovulatory follicle and then low LH concentrations continue to stimulate the CL to produce progesterone during the luteal phase, which lasts approximately 14 days. If pregnancy is not achieved following ovulation, the CL regresses and dies, and the cycle starts over.

The role of FSH, as described by the name, is to stimulate follicular development and maturation of one or more dominant follicles. The process of follicular growth and degeneration occurs throughout the entire estrous cycle — not only during the follicular phase. Increasing concentrations of FSH during the 
early follicular phase stimulate a follicular wave, or recruitment of a group of small antral follicles. All of the recruited follicles will begin to grow and secrete $E_{2}$. Typically only one or two follicles will develop dominance and go on to become preovulatory follicles, while the remaining follicles undergo atresia. Once the selected follicles establish dominance, they secrete $\mathrm{E}_{2}$ as well as inhibin which suppress FSH secretion from the anterior pituitary, thereby suppressing further follicular recruitment at that time.

\section{The Reproductive Cycle in Rodents}

In contrast to primates and sheep, rodent estrous cycles are much shorter, lasting only 4-5 days, and are made up of four parts: metestrus, diestrus, proestrus, and estrus. Follicles grow and develop during metestrus and diestrus, and on the afternoon of proestrus, a rise in $\mathrm{E}_{2}$ leads to the LH surge and ovulation. A day of estrus follows, during which time the female is sexually receptive. While the LH surge in rodents relies on elevated $\mathrm{E}_{2}$, similar to sheep, progesterone is also necessary for the full $\mathrm{LH}$ surge in rodents (5). The timing of the rodent LH surge is highly specific as well, with LH concentration starting to increase rapidly around 14:00 to 15:00 hours on the afternoon of proestrus, and reaching peak levels by 17:00 to 19:00 hours that day (6). Progesterone given early in the morning of proestrus has been shown to advance the LH surge by several hours (7). However, this role of progesterone in the surge is only observed in rodents. Ultimately, environmental light-dark cycles regulate timing of the surge. The light-dark signal is received by the eyes which have neural projections to the suprachiasmatic nuclei (SCN) of the hypothalamus $(8 ; 9)$. This environmental input is essential in regulating cyclicity in rats, as lesioning of the $\mathrm{SCN}$ has been shown to terminate the estrous cycle $(10 ; 11)$.

\section{CONTROL OF GNRH/LH SECRETION PATTERNS ACROSS THE CYCLE}

\section{E $_{2}$ Negative Feedback and Tonic GnRH/LH Secretion}

Two distinct patterns of GnRH/LH secretion have been identified in sheep (12), rodents $(13 ; 14)$, and primates (15). The chronic pulsatile release of $\mathrm{LH}$, referred to as tonic secretion, occurs throughout most of the follicular phase and during the luteal phase, and is characterized by brief periods of secretion followed by long periods of nonsecretion, which overall results in relatively low concentration of LH 
secretion. Maintenance of these low, tonic LH levels is accomplished, at least in part, by the inhibitory actions of low circulating $\mathrm{E}_{2}$ levels (referred to as $\mathrm{E}_{2}$-negative feedback), that are produced by growing ovarian follicles and progesterone from the CL. During the follicular phase, tonic secretion consists of GnRH/LH pulses that are high in frequency but low in amplitude, due to low levels of progesterone, which typically inhibits pulse frequency, and increasing $\mathrm{E}_{2}$ levels, which inhibits pulse amplitude (16). In contrast during the luteal phase, GnRH/LH pulses are low in frequency but high in amplitude (17) since progesterone is the dominant hormone during the luteal phase.

\section{2. $E_{2}$ Positive Feedback and the GnRH/LH Surge}

In contrast to tonic LH secretion, the GnRH/LH surge only occurs late in the follicular phase, when increasing $\mathrm{E}_{2}$ levels, produced by the preovulatory follicles, become stimulatory to $\mathrm{GnRH} / \mathrm{LH}$ secretion. This brief period surrounding the surge involves a switch to $E_{2}$ positive feedback. The increase in $E_{2}$ also induces estrus behavior (3). As a result of the LH surge, the preovulatory follicle bursts and the ovum is released, a process called ovulation. Post-ovulation, the remaining follicular tissue luteinizes and becomes the CL, which synthesizes and secretes progesterone throughout the luteal phase, as previously described above.

\section{THE ROLE OF E IN SEASONAL BREEDING}

Sheep are seasonally reproductive animals that express ovulatory cycles during the shorter days of fall and winter (breeding season), but then enter a period of anovulation during the longer days of spring and summer (anestrus). Seasonal breeding is thought to be of evolutionary advantage, allowing offspring to be born in the spring when the weather is more favorable and food is more abundant. It is widely known that sheep respond to changes in photoperiod to time breeding and anestrous seasons. The hormonal signal to which ewes respond is the change in release of melatonin from the pineal gland, which occurs at a higher rate in darkness (or night). Thereby, the duration of elevation in melatonin release is an index of day length. Seasonal breeders, like sheep, are able to interpret the melatonin signal in a way that influences GnRH release, although the pathway through which this occurs remains unclear. However, if ewes are exposed to extended periods of long days or short days, they will cease responding to daylength, 
a phenomenon known as "photorefractoriness" (18). This condition reflects an endogenous circannual rhythm for onset and offset of the breeding season that is evident in the absence of photoperiodic cues, because the rhythms in ewes deprived of photoperiod information become desynchronized, or freerunning (19-21).

Seasonal differences in sensitivity to $\mathrm{E}_{2}$ negative feedback appear to underlie seasonal breeding patterns in ewes. While progesterone primarily inhibits LH pulse frequency during the breeding season (16), $E_{2}$ is the main inhibitor of LH pulse frequency during the nonbreeding season (22). During anestrus, frequency of LH pulses is low in ovary-intact ewes, i.e. one pulse every 8-12 hours (23), a rate that is due to an increased sensitivity to $E_{2}$ negative feedback during this time (24) and one that is generally incapable of promoting follicular development. Thus, this low $\mathrm{GnRH} / \mathrm{LH}$ pulse frequency underlies the temporary quiescence of reproduction during anestrus (25); ovulatory mechanisms remain intact but are not activated in the absence of high, sustained $\mathrm{E}_{2}$ secretion. Thus, frequent injections of GnRH that increase tonic LH pulse frequency which stimulates estradiol secretion will result in ovulation in seasonally anestrus ewes $(26 ; 27)$. Anestrus continues as long as the photoperiod signal can maintain the inhibition of LH pulse frequency or until photorefractoriness occurs. During late summer/early fall, enhanced sensitivity to $E_{2}$ declines and pulse frequency increases, leading to a rise in $E_{2}$, and eventually ovulation, beginning a new breeding season.

\section{PATHWAY OF E FEEDBACK}

\section{Hypothalamic Sites of LH Regulation}

Halasz and Gorski (28) identified two major neural areas that are critical for normal pituitary function in rats. Using knife-cuts through different areas of the hypothalamus, Koves and Halasz (29) revealed that placing a cut behind the preoptic area (POA) of rats blocked the LH surge but had no effect on tonic LH secretion, from which they proposed that neurons of the POA are necessary for the preovulatory LH surge, while those in the medial basal hypothalamus (MBH) are required for tonic LH secretion (29). More specifically, the anteroventral periventricular nucleus (AVPV), a portion of the POA 
that closely borders the third ventricle in rodents, has been determined to regulate the $\mathrm{GnRH} / \mathrm{LH}$ surge since radiofrequency lesions of the AVPV block the surge (30), as do microimplants of an anti-estrogen placed in the AVPV (31).

While the POA appears to be critical for $\mathrm{E}_{2}$ positive feedback in rodents, it may not be as critical in sheep. Frontal hypothalamic deafferentation in ewes during the breeding season significantly decreased the magnitude of the LH surge, but did not interrupt normal ovulation and cycling (32). Moreover, increased activation of GnRH neurons, determined using cFos coexpression, occurs in both the POA as well as the MBH at the time of the GnRH surge in ewes (33), indicating involvement of both areas. cFos is an early, immediate gene product that is produced following the activation of a neuron, which has been widely used as an indicator of neuronal activation. The origin of the activation of the surge may lie in the $\mathrm{MBH}$, however, since estrogen-containing microimplants placed in or near the arcuate nucleus (ARC) of ewes induce an LH surge, while similar implants in the POA do not. This indicates that the estrogen positive feedback is exerted in or near the ovine ARC (34). Together, these studies suggest that activation of both areas may be required for the full LH surge, but that the MBH component alone is sufficient to produce the LH surge that induces ovulation.

The tonic $\mathrm{LH}$ control center has been identified as the $\mathrm{MBH}$ in rodents, as $\mathrm{E}_{2}$ treatment in this area has been confirmed to inhibit LH secretion (35;36). More specifically, the ARC has been identified as the site of episodic LH regulation using lesion and transection studies (37). Likewise, the ARC has been confirmed to be the site of tonic LH secretion in ewes. This was initially determined by the finding that knife cuts to the ARC disrupt pulsatile LH secretion, while cuts anterior to the ARC altered tonic LH secretion (38;39). Furthermore, GnRH neurons in the MBH, but not the POA, are activated, using Fos as an index of neural activation, when episodic LH secretion increases acutely (40). Multi-unit electrical recordings in the MBH have revealed bursts that correlated with LH pulses in goats (41). Together these and other studies confirmed that the ARC is the site of episodic LH regulation, and presumably $\mathrm{E}_{2}$ negative feedback. 


\section{2. $E_{2}$ Receptors}

For $E_{2}$ to impact neuronal function within the hypothalamus, there must be estrogen receptors (ER) present. While there are two isoforms of ER expressed in the hypothalamus, alpha and beta, ER $\alpha$ appears to be the key receptor mediating the hypothalamic effects of $E_{2}$ on GnRH/LH secretion. ER $\beta$ knockout mice do not exhibit any alterations in LH secretion, while ER $\alpha$ knockouts exhibit enhanced LH secretion, implicating this ER subtype in negative feedback (42). Furthermore, ER $\beta$ knockouts maintain the ability to produce an $\mathrm{E}_{2}$-induced GnRH surge, while ER $\alpha$ knockout mice do not (43), confirming that $\mathrm{ER} \alpha$ also is key in $\mathrm{E}_{2}$ positive feedback regulation.

Neurons containing ER $\alpha$ mRNA have been found to be concentrated in several hypothalamic areas including the POA, ventromedial nucleus, bed nucleus of the stria terminalis, supraoptic nucleus, $\mathrm{ARC}$, retrochiasmatic area $(\mathrm{RCh})$, subfornical organ, and lateral septum of sheep (44). Distribution of GnRH neurons and ER $\alpha$ expression overlap only in the POA and ARC in sheep (45), rats (46), and primates (47). However, few if any GnRH neurons in these species express ER $\alpha(45 ; 47-50)$. Therefore, $E_{2}$ feedback on GnRH release, whether positive or negative, is likely indirect and appears to be mediated via other hypothalamic neurons.

\section{ERa expression in a specific population of ARC neurons}

A few populations of hypothalamic neurons have been found to highly express ER $\alpha$. Of particular relevance to this dissertation are those ER $\alpha$-positive neurons expressing kisspeptin (51), neurokinin B (NKB) (48), or dynorphin (DYN) in the arcuate nucleus. Furthermore, it is common that all of these neuropeptides are found within the same neurons in the ARC. For example, most DYN neurons in the rat ARC express NKB, and vice versa (52), and high levels of colocalization of NKB and dynorphin were confirmed in the ovine ARC (53). High levels of coexpression of ARC (known as the infundibular nucleus in humans) kisspeptin and NKB has been observed in male rhesus monkeys (54) and humans (55). More recently, assessment of colocalization of these three neuropeptides led to the discovery that a single population of ARC neurons coexpresses kisspeptin, NKB, and DYN in sheep (56), mice (57), rats (52), and goats (41). Thus, this population was assigned the moniker KNDy (58). In humans, 
colocalization of kisspeptin and NKB in the infundibular nucleus has been confirmed (55), however, a recent study from the same lab failed to observe any detectable amounts of DYN in young male subjects, challenging the concept of cross species conservation of the presence of KNDy neurons (59).

Nonetheless, due to the intimate colocalization of the three peptides within KNDy neurons in multiple mammalian species, recent models suggest that these three neuropeptides work together to regulate tonic GnRH/LH secretion. Less is known about their possible collusion in regulating the GnRH/LH surge. In the following sections, I will consider each of these peptides separately and then describe a model regarding their potential interactions in tonic as well as surge LH secretion.

\section{KISSPEPTIN}

\section{Discovery}

The Kiss1 gene was first discovered as a human tumor metastasis-suppressor gene and given the name metastin (60). Another group working independently, named the peptide kisspeptin in honor of the

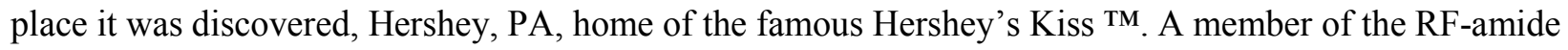
family of neuropeptides, kisspeptin is a 145 -amino acid peptide which can be truncated by posttranslational processing to $54,14,13$, or 10 amino acids, all of which are biologically active (61). Its receptor, GPR54 (or Kiss1r), is a G-protein coupled receptor that was originally identified as an orphan receptor (62;63). A loss-of-function mutation in GPR54 causes hypogonadotropic hypogonadism in humans, as identified in two different consanguineous families $(64 ; 65)$, demonstrating that the kisspeptinGPR54 interaction is essential to sexual maturation and fertility in humans. This discovery led to kisspeptin being the focus of much attention in the field then, and this interest still remains.

\section{Stimulation of GnRH/LH Secretion}

Kisspeptin has been confirmed as a potent stimulator of LH secretion in all species that have been studied including rodents (66;67), sheep (68;69), monkeys $(70 ; 71)$, and humans $(72 ; 73)$. Most kisspeptin neurons in the ovine hypothalamus express $\mathrm{ER} \alpha$, suggesting that $\mathrm{E}_{2}$ can act directly on kisspeptin neurons (51). Furthermore, from the high percentage of colocalization of GnRH neurons and Kiss 1r mRNA in 
both female mice (90\%) (74) and ewes (78-90\%) (75;76), it appears that kisspeptin can act directly to stimulate GnRH neurons

\section{Role of kisspeptin in rodents}

Two anatomically distinct populations of kisspeptin neurons are present in rodents, one in the AVPV and one in the ARC, as identified using both mRNA $(66 ; 77 ; 78)$ and protein $(77 ; 79)$. The AVPV population has been confirmed to mediate $\mathrm{E}_{2}$ positive feedback and the GnRH/LH surge based on the following reports: 1) infusion of anti-kisspeptin antibody into the POA (80), and more specifically the AVPV (77), abolished the LH surge in rats ,2) Kiss1 expression was reduced in the AVPV after ovariectomy, and increased with $\mathrm{E}_{2}$ treatment in mice (78) and rats (77), 3) Kiss1 mRNA levels and kisspeptin/c-Fos coexpression are highest in the AVPV on the evening of proestrus at the time of the LH surge in rats $(81), 4)$ Kiss 1 expression in the AVPV is sexually dimorphic, with female rats expressing significantly higher numbers of kisspeptin neurons than their male counterparts (82), an important sex difference since males do not typically exhibit LH surges (6).

In contrast to the AVPV population, ARC kisspeptin neurons appear to mediate $\mathrm{E}_{2}$ negative feedback in rodents. While one study found ARC kisspeptin neurons to exhibit increased Fos mRNA in mice during proestrus (80), a more recent study in rats found that kisspeptin neurons in the ARC do not express Fos at the time of the LH surge (81). Possible explanations for this discrepancy are: 1) the mice in the study by Kinoshita et al were killed early in the afternoon while the rats in the study by Smith et al were killed in the evening, so it could be an effect of timing 2) the mouse study used immunohistochemistry to detect kisspeptin positive cells while the rat study utilized in situ hybridization to detect Kiss 1 mRNA, so there could be differences in antibody specificity for kisspeptin. However, further research supports a role for ARC kisspeptin in tonic LH secretion. Kisspeptin cell numbers in this nucleus are not sexually dimorphic (82), which fits with both males and females exhibiting negative feedback regulation of tonic LH secretion by estradiol. Moreover, Kiss 1 expression in the ARC increases following OVX and decreases with $\mathrm{E}_{2}$ replacement (78). Therefore, it appears that in rodents the AVPV 
and ARC populations of kisspeptin neurons separately regulate the positive and negative feedback effects of $E_{2}$.

\section{Role of kisspeptin in sheep}

It is now generally accepted that kisspeptin plays an important role in both pulsatile and surge secretion of LH in sheep. Microinjection or microimplants containing Kiss1r-antagonist decrease LH pulse frequency in OVX ewes (83), which demonstrates the role of kisspeptin in tonic LH secretion. Similarly, ICV infusion of a kisspeptin receptor antagonist reduced the LH surge amplitude in ewes by $50 \%$ (76), indicating that kisspeptin is important for the LH surge, but it may not be solely responsible for it. These data also raise the possibility that other neuropeptides are involved in stimulating the full LH surge, although it is possible that the high dose of antagonist used in this experiment was not sufficient to block all of the Kiss1r and the remaining receptors were able to maintain half of the LH surge.

In ewes, kisspeptin-ir neurons are located in two distinct areas, the ARC $(51 ; 84 ; 85)$ and POA $(51 ; 85)$. Unlike rodents, sheep do not have a clearly defined AVPV, and ovine kisspeptin neurons are found more loosely scattered within the POA. In sheep, tonic and surge regulation of LH does not seem to be as clearly separated between kisspeptin populations as it is in rodents.

The majority of kisspeptin neurons are found in the ARC and OVX increases, while $\mathrm{E}_{2}$ treatment decreases, Kiss 1 mRNA in this area $(75 ; 85)$, implicating the ARC population in negative feedback regulation by $\mathrm{E}_{2}$. Furthermore, this population may also play a role in $\mathrm{E}_{2}$-positive feedback during the preovulatory GnRH surge. Kiss-1 mRNA expression was shown to be elevated in the caudal ARC during the LH surge (84), and the percentage of kisspeptin neurons coexpressing Fos, an index of neuronal activation, in this area increases $1 \mathrm{~h}$ after surge-inducing $\mathrm{E}_{2}$-treatment (75). However, contradictory data show that during the LH surge, less than $5 \%$ of kisspeptin neurons coexpress Fos in the ARC (86). As mentioned above, it is important to note that $\mathrm{E}_{2}$ treatment in this area has been shown to induce an LH surge (34), so ARC kisspeptin neurons may only be involved in the initiation of the surge.

Although the MBH appears to be important for generation of the GnRH surge in sheep, the role of the POA remains unclear. At one hour after surge-inducing $E_{2}$ treatment in OVX ewes, there was no 
change in kisspeptin/Fos coexpression in the POA; in contrast, during the late follicular phase in intact cycling ewes, Kiss 1 mRNA was significantly increased in the POA (75) and $\mathrm{E}_{2}$ increases kisspeptin expression in OVX ewes(87). Using a surge model, $\sim 50 \%$ of POA kisspeptin neurons were found to coexpress Fos at the time of the surge ( $26 \mathrm{~h}$ post- $\mathrm{E}_{2}$ treatment) while nearly none express Fos during tonic secretion in the luteal phase (86). Together, these data indicate that POA kisspeptin neurons may be important regulators of surge, but likely not tonic LH secretion in ewes. However, the role of ARC kisspeptin neurons remains controversial. Therefore, the first aim of my thesis was to assess which population of kisspeptin neurons mediates $E_{2}$-negative and $E_{2}$-positive feedback in ewes.

\section{NEUROKININ B}

\section{Discovery}

NKB is a member of the tachykinin family of neuropeptides, which also includes substance $\mathrm{P}$ (SP) and neurokinin A, among others. Tachykinins are peptides that contain the sequence Phe-X-GlyLeu-Met-NH2 at their carboxyl terminus, with the " $\mathrm{X}$ " being variable (88). Two genes encode for the family of tachykinins, with TAC3 specifically encoding the precursor for NKB (89). The tachykinins bind to the rhodopsin-like family of G-protein-coupled receptors (NK1R, NK2R, or NK3R) which share similar structures (90;91). Substance P and neurokinin A preferentially bind to NK1R and NK2R, respectively, while NKB has the highest affinity for NK3R. However, each of these tachykinins can interact with the other receptors when present at high concentrations (92-94). For most of the experiments herein I used senktide, an agonist that is highly specific for the NK3R receptor subtype (95).

\section{Stimulation of GnRH/LH Secretion}

NKB neurons are located mostly in the infundibular nucleus and the anterior hypothalamic area in humans (96). The first evidence for NKB playing a role in regulating LH secretion was reported in the early 1990's, when it was observed that a population of neurons in the infundibular nucleus of postmenopausal women highly expressing $\mathrm{ER} \alpha$ and NKB were found to be hypertrophied compared to these neurons in pre-menopausal women (97). Since menopause is associated with ovarian senescence, 
resulting in decreased $\mathrm{E}_{2}$ secretion and thus low negative feedback and elevated LH secretion, this finding indicated that the hypertrophy of NKB neurons may be responsible for the increased LH secretion. However, NKB's role in regulating LH release received only limited attention until it was discovered in 2009 that loss-of-function gene mutations in NKB (TAC3) or its receptor (TACR3) in humans result in infertility (98), thus clearly demonstrating that NKB is essential to human reproduction. Treatment of

males that express NKB or NK3R mutations with exogenous GnRH $(99 ; 100)$ or kisspeptin (101) restores fertility, suggesting that NKB acts via GnRH, either upstream of kisspeptin or independent of kisspeptin signaling.

\section{Role of NKB in rodents}

Neurons expressing NKB mRNA $(57 ; 102-104)$ or protein $(102-106)$ are found scattered throughout the hypothalamus and POA in rodents, with the majority of cells bodies found in the ARC. As is observed in humans, NKB cell numbers and gene expression in rodents are modulated by ovarian hormones, with numbers of detectable NKB neurons in ovary-intact rats being highest on the morning of proestrus and NKB expression increasing after OVX (107), relationships which suggest that NKB stimulates LH secretion in rodents. However, ICV injection of an NK3R agonist (senktide; 600 pmol/3 $\mu \mathrm{l})$ was found to inhibit $\mathrm{LH}$ secretion in $\mathrm{OVX}+\mathrm{E}_{2}$ rats (108). These initial conflicting results led to decreased interest in NKB as being important for regulating reproduction until the aforementioned loss of function mutation in humans was discovered.

Recent studies using rodents have consistently found that NK3R agonists stimulate LH secretion in gonadal intact mice $(109 ; 110)$ and rats $(111 ; 112)$, and inhibit LH secretion in OVX mice (57) and rats $(111 ; 112)$. The results of NK3R agonists in $\mathrm{OVX}+\mathrm{E}_{2}$ rodents are inconsistent, with no effect having been reported in mice $(57)$ and either inhibition or stimulation in rats $(108 ; 111 ; 112)$. Together these data lead to the conclusion that the effects of senktide (and presumably NKB) in rodents are dependent on steroid milieu (112). An important note on NKB in rodents is that NK3R-deficient mice remain fertile (113), albeit they are "sub-fertile" with a decrease in litter number as well as litter size (114). Thus, NKB may be less important in rodent reproduction than it is in humans and perhaps other species. 


\section{Role of NKB in sheep}

Neurons expressing NKB mRNA $(48 ; 115)$ and protein $(48 ; 53 ; 56)$ are found virtually exclusively in the ARC, and $97 \%$ coexpress $\mathrm{ER} \alpha(48)$. NKB appears to be regulated by estrogen in a negative manner, with OVX increasing NKB cell number in ewes (116) and short-term $\mathrm{E}_{2}$-treatment in OVX ewes inhibiting NKB mRNA expression and NKB-ir cell numbers (115). A stimulatory effect of NKB on LH secretion in ewes was confirmed by giving senktide via ICV injection in follicular phase or anestrous ewes (117) and ICV infusion of NKB in anestrous ewes (118). Additionally IV injection of senktide increases LH secretion in prepubertal female lambs (116). Thus, in contrast to the rodent data, work to date in the sheep indicates that senktide is stimulatory to LH secretion in follicular phase and OVX ewes, but has no effect in luteal phase ewes (117). This effect likely occurs exclusively through modulation of GnRH release since blocking GnRH actions at the anterior pituitary with a GnRH receptor antagonist also blocks the stimulation of LH release by senktide (116).

\section{Possible NKB Sites of Action}

NK3R expression is highest in four areas of the ovine hypothalamus; the RCh, ARC, POA, and PVN. The POA is also the location of most GnRH cell bodies; however, GnRH neurons in this area do not express NK3R (119). As previously mentioned, the ARC is thought to be the main site of $\mathrm{E}_{2}$ negative feedback in ewes and KNDy neurons in this area have been confirmed to coexpress NK3R (119), raising the possibility of autocrine or paracrine regulation of that population to possibly drive pulsatile LH secretion.

NKB-positive fibers with close appositions to GnRH cell bodies in sheep (48) and GnRH terminals were observed in the median eminence of sheep (53), rats (120), mice (57), and goats (41). However, the presence of NKB receptors on GnRH neurons in mice is unclear, as one study reports that GnRH neurons express $\operatorname{Tac} 3 r$ (121) and another report that no coexpression was found (112). Another study has reported low levels of NK3R expression in GnRH neurons in rats (120), but similar studies in sheep found no expression of NK3R on GnRH neurons (119). Therefore, the ability of NKB to directly 
act on GnRH neurons remains unclear. At least in male mice, senktide depolarizes kisspeptin neurons but not GnRH neurons in tissue slice preparations (110).

Our laboratory recently reported that senktide given in the RCh stimulates LH secretion in ewes, indicating that NK3R activation in this area is involved in regulating LH release (117). Interestingly, the increase in LH secretion did not seem to reflect an increase in LH pulse frequency, but instead was similar in profile to that seen during the LH surge, suggesting that NKB may have a role in $\mathrm{E}_{2}$ positive feedback as well. Lastly, the PVN has been documented as a site of LH control in fasted OVX rats, with local $\mathrm{E}_{2}$ treatment suppressing both mean plasma LH and LH pulse frequency (122). The effects of NKB or senktide in the POA, PVN, and ARC have not yet been evaluated. Therefore, the second aim in my dissertation work was to determine if NK3R activation in these areas alters LH secretion.

\section{DYNORPHIN A}

\section{Discovery}

The final KNDy neuropeptide to be discussed is dynorphin A (DYN). First identified in the pituitary (123-125), DYN is a member of a family of endogenous opioid peptides (EOPs), and is derived from the prodynorphin precursor. Other EOPs include the endorphins, such as $\beta$-endorphin, and the enkephalins. DYN is now known to play a role in regulating $\mathrm{GnRH} / \mathrm{LH}$ secretion in response to changes in circulating levels of gonadal steroids.

DYN neurons in the rat POA (126) and sheep POA, ARC, and anterior hypothalamus (127) highly express progesterone receptors (PR). Progesterone treatment has been shown to increase cerebral spinal fluid DYN concentration in OVX ewes (128). Furthermore, most ARC DYN neurons have been found to highly express ER- $\alpha$ in rats (52), which has also been inferred in sheep since all PR-positive neurons have previously been found to also express $\operatorname{ER} \alpha$ (129).

\section{DYN- א-opioid receptor (KOR) interaction}

EOPs act via three receptor subtypes: $\kappa^{-}, \mu-$, and $\delta$-. Dynorphin is the endogenous ligand for KOR (130) while endorphins and enkephalins have the highest affinity for binding to $\mu$-, and $\delta$-receptors (131). 
Most MBH GnRH neurons receive close contacts from DYN-containing varicosities in sheep (132) and rats (133). No $\mu$ - or $\kappa$-receptors were found to be coexpressed in GnRH neurons in female rats $(133 ; 134)$. Functional $\delta$-opioid receptors have been identified in a neuronal GnRH-producing cell line from mice (135). However, KOR have been shown to inhibit LH secretion in rats (136) and KOR antagonists increase LH in sheep (132).

\section{LH Surge Regulation by DYN}

EOPs are now generally thought to play an important role in the inhibitory control of GnRH/LH secretion, and removal of the inhibition, termed 'disinhibition', has been postulated to play a role in GnRH/LH surge regulation. Central infusion of a $\mu$-receptor agonist, but not a $\kappa$ - or $\delta$-agonist, delayed the LH surge in OVX ewes (137). This effect appears to be mediated at both the level of the POA or the MBH as bilateral infusion of a $\mu$-receptor agonist in either of these areas significantly delays the LH surge (138). However, the EOP antagonist naloxone does not advance the LH surge in sheep $(139 ; 140)$, suggesting that DYN does not appear to play a critical role in regulating the surge in sheep.

In support of the disinhibition hypothesis in rodents, blockade of KORs in the POA of rats on proestrus advanced the LH surge by $3 \mathrm{~h}$ (141). Treatment with DYN or KOR-agonists via ICV infusion blocks the endogenous LH surge on the afternoon of proestrus in rats (142). Therefore, disinhibition of DYN appears to be essential for the normal preovulatory LH surge in rats. The underlying control of this phenomenon remains unclear. However, it has been observed that KOR mRNA levels in the POA do not change during proestrus or diestrus while prodynorphin mRNA in the POA decreases at 1700-1800 $\mathrm{h}$ on proestrus compared to levels at $1300-1400 \mathrm{~h}$ (143), indicating that the disinhibition is likely a result of decreased DYN release.

\section{Negative Feedback Regulation on LH Secretion by DYN}

EOP antagonists failed to alter LH secretion in OVX or $\mathrm{E}_{2}$-treated OVX ewes, but significantly increased LH in OVX + progesterone ewes $(144 ; 145)$, suggesting that EOPs mediate the negative feedback actions of progesterone but do not mediate effects of $E_{2}$. Specifically, EOPs that act via $\mu-$ receptors and KOR have been implicated in mediating progesterone negative feedback in rodents 
$(146 ; 147)$ and sheep (132). Targeted extracellular recordings of KNDy neurons revealed that DYN decreases spontaneous neuron activity in intact mice (148). Recent work from our lab has shown that a KOR antagonist treatment in the ARC increases LH pulse frequency in OVX ewes, indicating that dynorphin can mediate progesterone-independent LH regulation (83). This phenomenon has also recently been reported in $\mathrm{E}_{2}$-treated OVX rats (149), which suggests that dynorphin may also mediate some type of $E_{2}$ negative feedback. In conclusion, while DYN is widely accepted as an inhibitor of LH secretion across species, the pathway through which it acts, as well as the influence on its actions by steroid hormones, remains under investigation.

\section{THE KNDY NEURAL NETWORK}

\section{KNDy-GnRH Neuron Interaction}

As discussed above, all three neuropeptides expressed in KNDy neurons have been identified as playing important roles in the regulation of GnRH secretion; therefore, the interaction between KNDy and GnRH neurons is of considerable interest. Because the colocalization of these three peptides has been observed only in the ARC, ICC labeling for multiple KNDy peptides within the same terminals was utilized to identify targets of KNDy output. In ewes, KNDy fibers were observed in close contact with GnRH neurons in both the POA and the MBH (58). This finding is consistent with previous data showing that kisspeptin, NKB, or dynorphin fibers alone have direct input to GnRH neurons in rats $(80 ; 150)$, mice (79), and sheep (132), as well as in humans (151). However, in those studies, it cannot be concluded that the projections are coming from KNDy neurons, since only one peptide was assessed and these peptides are independently expressed in various areas of the brain. KNDy neurons have also been shown to project to the ME with close appositions to GnRH neuron terminals in rodents (150), monkeys (152), and sheep $(58 ; 76)$. 


\section{Reciprocal Innervations amongst KNDy Neurons}

When considering how KNDy neurons act to regulate GnRH release, one interesting feature of this population is that almost all of them receive input from other KNDy neurons. Specifically, duallabeling revealed that NKB/DYN-positive fibers form close contacts with NKB/DYN-positive cell bodies in the ovine ARC (53). Since NKB expression is limited to the ARC in sheep, this innervation can only come from other ARC KNDy neurons. Similar findings have been reported for rats (52). KNDy neurons have been confirmed to express NK3R in sheep (119). Furthermore, tract tracing studies have identified NKB-positive axons in the ARC terminating on other NKB-ir neurons in the same area and upon KNDy neurons in the contralateral ARC in rats (105) and goats (153).

These data strongly support the feasibility of KNDy neurons acting as a reciprocal network via local NKB and possibly DYN secretion. Given what is known about locations of receptors for the various KNDy peptides and this reciprocity, it has been hypothesized that NKB and dynorphin may act in a paracrine or autocrine fashion to regulate kisspeptin output, which then influences GnRH release.

KNDy neurons in rats express NK3R (52) and in mice KNDy neurons express both NK3R and low levels of KOR (57), suggesting the interaction of the KNDy neuropeptides is similar to that in sheep. However, data from studies on DYN yield varying results. Ovarian steroids have been shown to inhibit prepro-DYN mRNA in the ARC of mice, and KOR knockout was found to decrease LH secretion in OVX mice (57). Therefore the role of DYN in rodents remains unclear.

\section{NKB May Act via Kisspeptin}

Certain aspects of this hypothesis have been tested using pharmacological approaches. Support for the idea that NKB acts upstream of kisspeptin in rodents lies in the finding that senktide injection in $\mathrm{OVX}+\mathrm{E}_{2}$ rats activates ARC kisspeptin neurons, as indicated by increased Fos colocalization (112), and that senktide stimulates LH secretion in wild-type male mice but has no effect on LH release in Kissr1 knockout counterparts (109). Recent work indicates that senktide administration in OVX rats may inhibit LH secretion via a KOR-dependent mechanism, possibly by recruiting DYN to activate the KOR (154), further suggesting an intimate interaction occurs between neuropeptides within the KNDy neural network 
in rodents. Additionally, work in primates found that down-regulation of Kiss 1r abolished the senktideinduced stimulation of GnRH secretion, indicating that NKB action upstream of kisspeptin is likely conserved across species (155).

In ewes, ICV infusion of NKB increases activation of kisspeptin neurons in the caudal ARC of anestrous ewes (118), although where NKB acts within the hypothalamus to do this cannot be determined using this approach. Nonetheless, these findings support the hypothesis that NKB is altering GnRH/LH secretion via kisspeptin release from KNDy neurons.

While the findings from these aforementioned studies postulated that NKB is acting directly upon KNDy neurons to increase kisspeptin, it is also possible that kisspeptin mediates NKB action in other areas of the hypothalamus. This hypothesis will be addressed in my final aim, by assessing both ARC and POA kisspeptin neuron activation following NKB or senktide treatment in various areas of the hypothalamus.

\section{KNDy Neurons as the Pulse Generator: Current Ovine Model}

Many facets of data have been combined to postulate a current model for the GnRH pulse generator in ewes and goats. Studies assessing multi-unit electrical activity (MUA) recorded near KNDy neurons in goats have shown that MUA volleys recorded in the ARC coincide with LH pulses (41). This MUA data together with the anatomical observations and pharmacological evidence regarding KNDy neurons gives rise to a model for GnRH/LH pulse generation. Kisspeptin is suggested to be the output from the KNDy neuron network to GnRH neurons in both the POA and MBH. Kiss1r expression in GnRH neurons along with data in mice showing that kisspeptin application directly excites GnRH neurons (156) strongly indicate that kisspeptin acts directly to influence GnRH release. However, it is possible that other more indirect pathways are involved as well. The currently proposed model (Figure 1A) for KNDy neuron regulation of GnRH secretion in sheep involves NKB and DYN acting within the KNDy network while kisspeptin serves as the output from KNDy neurons to GnRH neurons (58). Further, a model for the switching on/off of pulses within the KNDy network has been proposed (Figure 1B)(58). This model suggests that the interplay between peptides may underlie GnRH pulse generation, i.e. NKB 
release from KNDy neurons likely stimulates other KNDy neurons through extensive reciprocal innervations, ultimately causing kisspeptin release which acts to stimulate GnRH release and initiate pulse onset. Dynorphin may then serve as the brake to terminate the pulse of GnRH secretion. Recent data from our laboratory demonstrated that ARC administration of either a Kiss1r antagonist or an NKB receptor antagonist inhibited LH pulse frequency while NKB or an antagonist to KOR increased LH pulse frequency in OVX ewes, supporting the roles that have been previously proposed for each of these neuropeptides in the pulse generator model (157). Also, administration of either senktide or nor-BNI increases MUA volley frequency in goats, supporting a role for NKB and DYN in pulse regulation (153). 

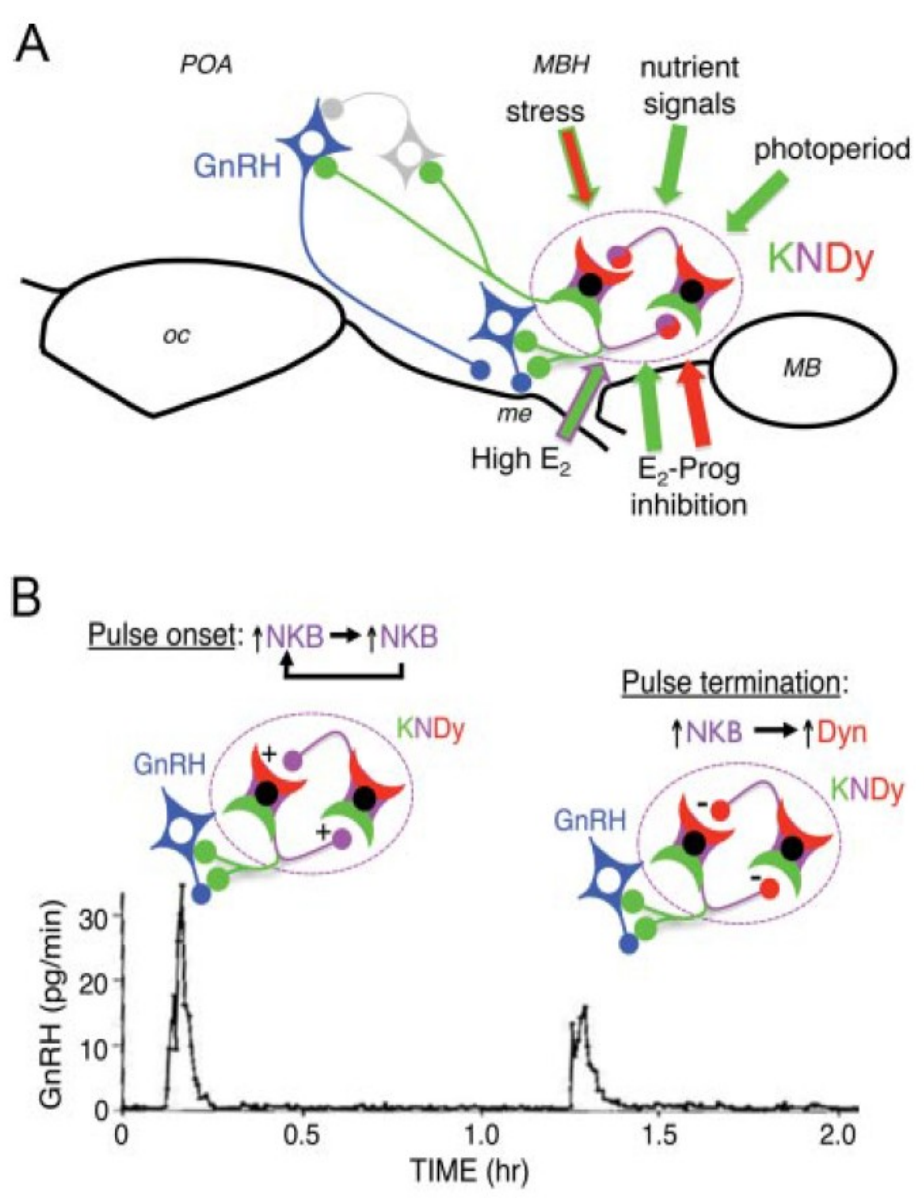

Figure 1: A) Schematic of the current model for KNDy neuron interaction with GnRH neurons. B) Model describing the role for NKB and DYN in LH pulse regulation (from Lehman et al, 2010). 


\section{KNDy Neurons as the Preovulatory Surge Regulator: Current Ovine Model}

For $E_{2}$-positive feedback, the current working hypothesis is that high levels of $E_{2}$ also act on the KNDy neurons in a stimulatory fashion to trigger a sequence of events that differ from those that occur during negative feedback. Increased Fos expression in KNDy neurons, but not POA kisspeptin neurons, was observed at $1 \mathrm{~h}$ after injection of a surge-inducing dose of $E_{2}$ in ewes and Kiss1 mRNA is elevated in the POA kisspeptin neurons during the late follicular phase (75), indicating that the initial effects of $E_{2}$ on KNDy neurons may lead to later activation of POA kisspeptin neurons during the LH surge. Furthermore, several other neurotransmitters have also been implicated in the control of the GnRH/LH surge (3). VMN somatostatin neurons express ER- $\alpha$ (158), and $\mathrm{E}_{2}$ treatment has been shown to increase somatostatin mRNA during the LH surge (159). Somatostatin neurons also highly express Fos during the surge (158); however, $\mathrm{E}_{2}$ treatment in the VMN failed to induce Fos in these neurons (160). Furthermore, somatostatin treatment in OVX ewes inhibited LH secretion (159), conflicting with the idea that somatostatin may play a role in inducing the $\mathrm{LH}$ surge.

Norepinephrine (NE) has also been postulated to play a role in surge regulation, since $\mathrm{E}_{2}$ increases Fos expression in A1 NE neurons in ewes (161). Concentrations of NE increase in the ME during the GnRH surge (162), further indicating a role for NE involvement in the surge. However, treatment with an adrenergic antagonist was unable to consistently block an $\mathrm{E}_{2}$-induced LH surge (163), suggesting endogenous NE may not play a vital role in the LH surge.

The involvement of these and other neurotransmitters in surge regulation suggests the likely possibility that that $E_{2}$ acts via multiple pathways and in several areas within and without the hypothalamus to induce the preovulatory GnRH surge. The possible involvement of NKB in the LH surge is unknown. Therefore, elucidating that role is the overall aim of this dissertation, which is broken-down into the following three specific aims. 


\section{PROJECT AIMS}

Specific Aim 1: Determine which population of kisspeptin neurons mediates $\mathbf{E}_{2}$-negative and $\mathbf{E}_{2^{-}}$ positive feedback.

We will address this aim by evaluating if the POA and/or ARC population of kisspeptin neurons are activated, as determined by coexpression of $\mathrm{cFos}$, either by decreased $\mathrm{E}_{2}$-negative feedback (following ovariectomy, when LH pulse frequency is high) or during an $\mathrm{E}_{2}$-induced LH surge.

Specific Aim 2: Determine in which area(s) of the hypothalamus activation of NK3R induce surgelike LH secretion and which of these are important for the LH surge.

We will address this aim by placing NKB or senktide the RCh, POA, PVN, and ARC and examining LH secretion. Next, we will determine if activation of NK3R in the areas where we observe a response to senktide is necessary for an $\mathrm{E}_{2}$-induced surge by placing an NK3R antagonist into these areas during an $\mathrm{E}_{2}$-induced LH surge.

Specific Aim 3: Determine if NKB acts via kisspeptin and/or through alternative pathways to alter

\section{LH secretion.}

This aim will be addressed by two approaches: 1) determine whether activation of NK3R in specific hypothalamic areas increases Fos expression in KNDy neurons or POA kisspeptin neurons, in conjunction with stimulating LH secretion, 2) determine if blocking Kiss 1r alters the senktide-induced stimulation of LH secretion. 
Reference List

1. Advis JP, Kuljis RO, Dey G 1985 Distribution of luteinizing hormone-releasing hormone (LHRH) content and total LHRH-degrading activity (LHRH-DA) in the hypothalamus of the ewe. Endocrinology 116:2410-2418

2. Lehman MN, Robinson JE, Karsch FJ, Silverman AJ 1986 Immunocytochemical localization of luteinizing hormone-releasing hormone (LHRH) pathways in the sheep brain during anestrus and the mid-luteal phase of the estrous cycle. J Comp Neurol 244:19-35

3. Goodman RL, Inskeep EI 2006 Neuroendocrine Control of the Ovarian Cycle of the Sheep. Knobil and Neill's Physiology of Reproduction. 3rd ed.

4. Zeleznik AJ 2006 Control of Follicular Development, Corpus Luteum Function, the Maternal Recognition of Pregnancy, and the Neuroendocrine Regulation of the Menstrual Cycle in Higher Primates. Knobil and Neill's Physiology of Reproduction. 3rd ed.; 2449-2510

5. Caligaris L, Astrada JJ, Taleisnik S 1971 Biphasic effect of progesterone on the release of gonadotropin in rats. Endocrinology 89:331-337

6. Freeman ME 2006 Neuroendocrine Control of the Ovarian Cycle of the Rat. Knobil and Neill's Physiology of Reproduction. 3rd ed.; 2327-2388

7. Brown-Grant K, Naftolin F 1972 Facilitation of luteinizing hormone secretion in the female rat by progesterone. J Endocrinol 53:37-46

8. Berk ML, Finkelstein JA 1981 An autoradiographic determination of the efferent projections of the suprachiasmatic nucleus of the hypothalamus. Brain Res 226:1-13

9. Stephan FK, Berkley KJ, Moss RL 1981 Efferent connections of the rat suprachiasmatic nucleus. Neuroscience 6:2625-2641

10. Nunez AA, Stephan FK 1977 The effects of hypothalamic knife cuts on drinking rhythms and the estrus cycle of the rat. Behav Biol 20:224-234

11. Raisman G, Brown-Grant K 1977 The 'suprachiasmatic syndrome': endocrine and behavioural abnormalities following lesions of the suprachiasmatic nuclei in the female rat. Proc R Soc Lond B Biol Sci 198:297-314

12. Goding JR, Blockey MA, Brown JM, Catt KJ, Cumming IA 1970 The role of estrogen in the control of the estrus cycle in the ewe. J Reprod Fertil 21:368-369

13. Gallo RV 1981 Pulsatile LH release during periods of low level LH secretion in the rat estrous cycle. Biol Reprod 24:771-777

14. Higuchi T, Kawakami M 1982 Changes in the characteristics of pulsatile luteinizing hormone secretion during the oestrous cycle and after ovariectomy and oestrogen treatment in female rats. J Endocrinol 94:177-182

15. Dierschke DJ, Bhattacharya AN, Atkinson LE, Knobil E 1970 Circhoral oscillations of plasma LH levels in the ovariectomized rhesus monkey. Endocrinology 87:850-853 
16. Goodman RL, Karsch FJ 1980 Pulsatile secretion of luteinizing hormone: differential suppression by ovarian steroids. Endocrinology 107:1286-1290

17. Moenter SM, Caraty A, Locatelli A, Karsch FJ 1991 Pattern of gonadotropin-releasing hormone $(\mathrm{GnRH})$ secretion leading up to ovulation in the ewe: existence of a preovulatory $\mathrm{GnRH}$ surge. Endocrinology 129:1175-1182

18. Robinson JE, Karsch FJ 1984 Refractoriness to inductive day lengths terminates the breeding season of the Suffolk ewe. Biol Reprod 31:656-663

19. Karsch FJ, Robinson JE, Woodfill CJ, Brown MB 1989 Circannual cycles of luteinizing hormone and prolactin secretion in ewes during prolonged exposure to a fixed photoperiod: evidence for an endogenous reproductive rhythm. Biol Reprod 41:1034-1046

20. Woodfill CJ, Robinson JE, Malpaux B, Karsch FJ 1991 Synchronization of the circannual reproductive rhythm of the ewe by discrete photoperiodic signals. Biol Reprod 45:110-121

21. Woodfill CJ, Wayne NL, Moenter SM, Karsch FJ 1994 Photoperiodic synchronization of a circannual reproductive rhythm in sheep: identification of season-specific time cues. Biol Reprod 50:965-976

22. Goodman RL, Bittman EL, Foster DL, Karsch FJ 1982 Alterations in the control of luteinizing hormone pulse frequency underlie the seasonal variation in estradiol negative feedback in the ewe. Biol Reprod 27:580-589

23. Goodman RL, Bittman EL, Foster DL, Karsch FJ 1981 The endocrine basis of the synergistic suppression of luteinizing hormone by estradiol and progesterone. Endocrinology 109:1414-1417

24. Legan SJ, Karsch FJ, Foster DL 1977 The endocrin control of seasonal reproductive function in the ewe: a marked change in response to the negative feedback action of estradiol on luteinizing hormone secretion. Endocrinology 101:818-824

25. Legan SJ, I'Anson H, Fitzgerald BP, Fitzovich D 1985 Does the seasonal increase in estradiol negative feedback prevent luteinizing hormone surges in anestrous ewes by suppressing hypothalamic gonadotropin-releasing hormone pulse frequency? Biol Reprod 33:117-131

26. McLeod BJ, Haresign W, Lamming GE 1982 Response of seasonally anoestrous ewes to small-dose multiple injections of Gn-RH with and without progesterone pretreatment. J Reprod Fertil 65:223-230

27. McNeilly AS, O'Connell M, Baird DT 1982 Induction of ovulation and normal luteal function by pulsed injections of luteinizing hormone in anestrous ewes. Endocrinology 110:1292-1299

28. Halasz B, Gorski RA 1967 Gonadotrophic hormone secretion in female rats after partial or total interruption of neural afferents to the medial basal hypothalamus. Endocrinology 80:608-622

29. Koves K, Halasz B 1970 Location of the neural structures triggering ovulation in the rat. Neuroendocrinology 6:180-193 
30. Wiegand SJ, Terasawa E, Bridson WE, Goy RW 1980 Effects of discrete lesions of preoptic and suprachiasmatic structures in the female rat. Alterations in the feedback regulation of gonadotropin secretion. Neuroendocrinology 31:147-157

31. Petersen SL, Barraclough CA 1989 Suppression of spontaneous LH surges in estrogen-treated ovariectomized rats by microimplants of antiestrogens into the preoptic brain. Brain Res 484:279289

32. Pau KF, Kuehl DE, Jackson GL 1982 Effect of frontal hypothalamic deafferentation on luteinizing hormone secretion and seasonal breeding in the ewe. Biol Reprod 27:999-1009

33. Moenter SM, Karsch FJ, Lehman MN 1993 Fos expression during the estradiol-induced gonadotropin-releasing hormone $(\mathrm{GnRH})$ surge of the ewe: induction in $\mathrm{GnRH}$ and other neurons. Endocrinology 133:896-903

34. Caraty A, Fabre-Nys C, Delaleu B, Locatelli A, Bruneau G, Karsch FJ, Herbison A 1998 Evidence that the mediobasal hypothalamus is the primary site of action of estradiol in inducing the preovulatory gonadotropin releasing hormone surge in the ewe. Endocrinology 139:17521760

35. Blake CA 1977 A medial basal hypothalamic site of synergistic action of estrogen and progesterone on the inhibition of pituitary luteinizing hormone release. Endocrinology 101:11301134

36. Smith ER, Davidson JM 1974 Location of feedback receptors: effects of intracranially implanted steroids on plasma LH and LRF response. Endocrinology 95:1566-1573

37. Soper BD, Weick RF 1980 Hypothalamic and extrahypothalamic mediation of pulsatile discharges of luteinizing hormone in the ovariectomized rat. Endocrinology 106:348-355

38. Jackson GL, Kuehl D, McDowell K, Zaleski A 1978 Effect of hypothalamic deafferentation on secretion of luteinizing hormone in the ewe. Biol Reprod 18:808-819

39. Thiery JC, Signoret JP, Blanc M, Pelletier J, Ravault JP, Caraty A, Lavenet C, Orgeur P, Potrier JC, Venier G 1977 Effects of anterior hypothalamic deafferentation on LH, FSH, prolactin and sexual behavior in the ovariectomized ewe. Irc Med Sci Reprod Obstet Gynecol $5: 434$

40. Boukhliq R, Goodman RL, Berriman SJ, Adrian B, Lehman MN 1999 A subset of gonadotropin-releasing hormone neurons in the ovine medial basal hypothalamus is activated during increased pulsatile luteinizing hormone secretion. Endocrinology 140:5929-5936

41. Wakabayashi Y, Nakada T, Murata K, Ohkura S, Mogi K, Navarro VM, Clifton DK, Mori Y, Tsukamura H, Maeda K, Steiner RA, Okamura H 2010 Neurokinin B and dynorphin A in kisspeptin neurons of the arcuate nucleus participate in generation of periodic oscillation of neural activity driving pulsatile gonadotropin-releasing hormone secretion in the goat. J Neurosci 30:3124-3132

42. Couse JF, Yates MM, Walker VR, Korach KS 2003 Characterization of the hypothalamicpituitary-gonadal axis in estrogen receptor (ER) Null mice reveals hypergonadism and endocrine sex reversal in females lacking ERalpha but not ERbeta. Mol Endocrinol 17:1039-1053 
43. Wintermantel TM, Campbell RE, Porteous R, Bock D, Grone HJ, Todman MG, Korach KS, Greiner E, Perez CA, Schutz G, Herbison AE 2006 Definition of estrogen receptor pathway critical for estrogen positive feedback to gonadotropin-releasing hormone neurons and fertility. Neuron 52:271-280

44. Scott CJ, Tilbrook AJ, Simmons DM, Rawson JA, Chu S, Fuller PJ, Ing NH, Clarke IJ 2000 The distribution of cells containing estrogen receptor-alpha (ERalpha) and ERbeta messenger ribonucleic acid in the preoptic area and hypothalamus of the sheep: comparison of males and females. Endocrinology 141:2951-2962

45. Lehman MN, Karsch FJ 1993 Do gonadotropin-releasing hormone, tyrosine hydroxylase-, and beta-endorphin-immunoreactive neurons contain estrogen receptors? A double-label immunocytochemical study in the Suffolk ewe. Endocrinology 133:887-895

46. Pfaff D, Keiner M 1973 Atlas of estradiol-concentrating cells in the central nervous system of the female rat. J Comp Neurol 151:121-158

47. Herbison AE, Horvath TL, Naftolin F, Leranth C 1995 Distribution of estrogen receptorimmunoreactive cells in monkey hypothalamus: relationship to neurones containing luteinizing hormone-releasing hormone and tyrosine hydroxylase. Neuroendocrinology 61:1-10

48. Goubillon ML, Forsdike RA, Robinson JE, Ciofi P, Caraty A, Herbison AE 2000 Identification of neurokinin B-expressing neurons as an highly estrogen-receptive, sexually dimorphic cell group in the ovine arcuate nucleus. Endocrinology 141:4218-4225

49. Legan SJ, Tsai HW 2003 Oestrogen receptor-alpha and -beta immunoreactivity in gonadotropinreleasing hormone neurones after ovariectomy and chronic exposure to oestradiol. J Neuroendocrinol 15:1164-1170

50. Sullivan KA, Witkin JW, Ferin M, Silverman AJ 1995 Gonadotropin-releasing hormone neurons in the rhesus macaque are not immunoreactive for the estrogen receptor. Brain Res 685:198-200

51. Franceschini I, Lomet D, Cateau M, Delsol G, Tillet Y, Caraty A 2006 Kisspeptin immunoreactive cells of the ovine preoptic area and arcuate nucleus co-express estrogen receptor alpha. Neuroscience Letters 401:225-230

52. Burke MC, Letts PA, Krajewski SJ, Rance NE 2006 Coexpression of dynorphin and neurokinin B immunoreactivity in the rat hypothalamus: Morphologic evidence of interrelated function within the arcuate nucleus. J Comp Neurol 498:712-726

53. Foradori CD, Amstalden M, Goodman RL, Lehman MN 2006 Colocalisation of dynorphin a and neurokinin B immunoreactivity in the arcuate nucleus and median eminence of the sheep. Journal of Neuroendocrinology 18:534-541

54. Ramaswamy S, Seminara SB, Ali B, Ciofi P, Amin NA, Plant TM 2010 Neurokinin B stimulates GnRH release in the male monkey (Macaca mulatta) and is colocalized with kisspeptin in the arcuate nucleus. Endocrinology 151:4494-4503 
55. Hrabovszky E, Ciofi P, Vida B, Horvath MC, Keller E, Caraty A, Bloom SR, Ghatei MA, Dhillo WS, Liposits Z, Kallo I 2010 The kisspeptin system of the human hypothalamus: sexual dimorphism and relationship with gonadotropin-releasing hormone and neurokinin B neurons. Eur J Neurosci 31:1984-1998

56. Goodman RL, Lehman MN, Smith JT, Coolen LM, de Oliveira CV, Jafarzadehshirazi MR, Pereira A, Iqbal J, Caraty A, Ciofi P, Clarke IJ 2007 Kisspeptin neurons in the arcuate nucleus of the ewe express both dynorphin A and neurokinin B. Endocrinology 148:5752-5760

57. Navarro VM, Gottsch ML, Chavkin C, Okamura H, Clifton DK, Steiner RA 2009 Regulation of gonadotropin-releasing hormone secretion by kisspeptin/dynorphin/neurokinin B neurons in the arcuate nucleus of the mouse. J Neurosci 29:11859-11866

58. Lehman MN, Coolen LM, Goodman RL 2010 Minireview: Kisspeptin/Neurokinin B/Dynorphin (KNDy) Cells of the Arcuate Nucleus: A Central Node in the Control of Gonadotropin-Releasing Hormone Secretion. Endocrinology 151:3479-3489

59. Hrabovszky E, Sipos MT, Molnar CS, Ciofi P, Borsay BA, Gergely P, Herczeg L, Bloom SR, Ghatei MA, Dhillo WS, Liposits Z 2012 Low degree of overlap between kisspeptin, neurokinin $\mathrm{B}$, and dynorphin immunoreactivities in the infundibular nucleus of young male human subjects challenges the KNDy neuron concept. Endocrinology 153:4978-4989

60. Lee JH, Miele ME, Hicks DJ, Phillips KK, Trent JM, Weissman BE, Welch DR 1996 KiSS1, a novel human malignant melanoma metastasis-suppressor gene. J Natl Cancer Inst 88:17311737

61. Muir AI, Chamberlain L, Elshourbagy NA, Michalovich D, Moore DJ, Calamari A, Szekeres PG, Sarau HM, Chambers JK, Murdock P, Steplewski K, Shabon U, Miller JE, Middleton SE, Darker JG, Larminie CG, Wilson S, Bergsma DJ, Emson P, Faull R, Philpott KL, Harrison DC 2001 AXOR12, a novel human G protein-coupled receptor, activated by the peptide KiSS-1. J Biol Chem 276:28969-28975

62. Kotani M, Detheux M, Vandenbogaerde A, Communi D, Vanderwinden JM, Le PE, Brezillon S, Tyldesley R, Suarez-Huerta N, Vandeput F, Blanpain C, Schiffmann SN, Vassart G, Parmentier M 2001 The metastasis suppressor gene KiSS-1 encodes kisspeptins, the natural ligands of the orphan G protein-coupled receptor GPR54. J Biol Chem 276:34631-34636

63. Ohtaki T, Shintani Y, Honda S, Matsumoto H, Hori A, Kanehashi K, Terao Y, Kumano S, Takatsu Y, Masuda Y, Ishibashi Y, Watanabe T, Asada M, Yamada T, Suenaga M, Kitada C, Usuki S, Kurokawa T, Onda H, Nishimura O, Fujino M 2001 Metastasis suppressor gene KiSS-1 encodes peptide ligand of a G-protein-coupled receptor. Nature 411:613-617

64. de Roux N, Genin E, Carel JC, Matsuda F, Chaussain JL, Milgrom E 2003 Hypogonadotropic hypogonadism due to loss of function of the KiSS1-derived peptide receptor GPR54. Proc Natl Acad Sci U S A 100:10972-10976

65. Seminara SB, Messager S, Chatzidaki EE, Thresher RR, Acierno JS, Jr., Shagoury JK, BoAbbas Y, Kuohung W, Schwinof KM, Hendrick AG, Zahn D, Dixon J, Kaiser UB, Slaugenhaupt SA, Gusella JF, O'Rahilly S, Carlton MB, Crowley WF, Jr., Aparicio SA, Colledge WH 2003 The GPR54 gene as a regulator of puberty. N Engl J Med 349:1614-1627 
66. Gottsch ML, Cunningham MJ, Smith JT, Popa SM, Acohido BV, Crowley WF, Seminara S, Clifton DK, Steiner RA 2004 A role for kisspeptins in the regulation of gonadotropin secretion in the mouse. Endocrinology 145:4073-4077

67. Navarro VM, Castellano JM, Fernandez-Fernandez R, Barreiro ML, Roa J, SanchezCriado JE, Aguilar E, Dieguez C, Pinilla L, Tena-Sempere M 2004 Developmental and hormonally regulated messenger ribonucleic acid expression of KiSS-1 and its putative receptor, GPR54, in rat hypothalamus and potent luteinizing hormone-releasing activity of KiSS-1 peptide. Endocrinology 145:4565-4574

68. Arreguin-Arevalo JA, Lents CA, Farmerie TA, Nett TM, Clay CM 2007 KiSS-1 peptide induces release of LH by a direct effect on the hypothalamus of ovariectomized ewes. Anim Reprod Sci 101:265-275

69. Messager S, Chatzidaki EE, Ma D, Hendrick AG, Zahn D, Dixon J, Thresher RR, Malinge I, Lomet D, Carlton MB, Colledge WH, Caraty A, Aparicio SA 2005 Kisspeptin directly stimulates gonadotropin-releasing hormone release via $G$ protein-coupled receptor 54 . Proc Natl Acad Sci U S A 102:1761-1766

70. Plant TM 2006 The role of KiSS-1 in the regulation of puberty in higher primates. Eur J Endocrinol 155 Suppl 1:S11-S16

71. Shahab M, Mastronardi C, Seminara SB, Crowley WF, Ojeda SR, Plant TM 2005 Increased hypothalamic GPR54 signaling: a potential mechanism for initiation of puberty in primates. Proc Natl Acad Sci U S A 102:2129-2134

72. Dhillo WS, Chaudhri OB, Patterson M, Thompson EL, Murphy KG, Badman MK, McGowan BM, Amber V, Patel S, Ghatei MA, Bloom SR 2005 Kisspeptin-54 stimulates the hypothalamic-pituitary gonadal axis in human males. J Clin Endocrinol Metab 90:6609-6615

73. Dhillo WS, Chaudhri OB, Thompson EL, Murphy KG, Patterson M, Ramachandran R, Nijher GK, Amber V, Kokkinos A, Donaldson M, Ghatei MA, Bloom SR 2007 Kisspeptin-54 stimulates gonadotropin release most potently during the Preovulatory phase of the menstrual cycle in women. Journal of Clinical Endocrinology \& Metabolism 92:3958-3966

74. Han SK, Gottsch ML, Lee KJ, Popa SM, Smith JT, Jakawich SK, Clifton DK, Steiner RA, Herbison AE 2005 Activation of gonadotropin-releasing hormone neurons by kisspeptin as a neuroendocrine switch for the onset of puberty. J Neurosci 25:11349-11356

75. Smith JT, Li Q, Pereira A, Clarke IJ 2009 Kisspeptin neurons in the ovine arcuate nucleus and preoptic area are involved in the preovulatory luteinizing hormone surge. Endocrinology 150:5530-5538

76. Smith JT, Li Q, Yap KS, Shahab M, Roseweir AK, Millar RP, Clarke IJ 2011 Kisspeptin is essential for the full preovulatory LH surge and stimulates GnRH release from the isolated ovine median eminence. Endocrinology 152:1001-1012

77. Adachi S, Yamada S, Takatsu Y, Matsui H, Kinoshita M, Takase K, Sugiura H, Ohtaki T, Matsumoto H, Uenoyama Y, Tsukamura H, Inoue K, Maeda K 2007 Involvement of anteroventral periventricular metastin/kisspeptin neurons in estrogen positive feedback action on luteinizing hormone release in female rats. J Reprod Dev 53:367-378 
78. Smith JT, Cunningham MJ, Rissman EF, Clifton DK, Steiner RA 2005 Regulation of Kiss 1 gene expression in the brain of the female mouse. Endocrinology 146:3686-3692

79. Clarkson J, Herbison AE 2006 Postnatal development of kisspeptin neurons in mouse hypothalamus; sexual dimorphism and projections to gonadotropin-releasing hormone neurons. Endocrinology 147:5817-5825

80. Kinoshita M, Tsukamura H, Adachi S, Matsui H, Uenoyama Y, Iwata K, Yamada S, Inoue K, Ohtaki T, Matsumoto H, Maeda K 2005 Involvement of central metastin in the regulation of preovulatory luteinizing hormone surge and estrous cyclicity in female rats. Endocrinology $146: 4431-4436$

81. Smith JT, Popa SM, Clifton DK, Hoffman GE, Steiner RA 2006 Kiss 1 neurons in the forebrain as central processors for generating the preovulatory luteinizing hormone surge. $\mathrm{J}$ Neurosci 26:6687-6694

82. Kauffman AS, Gottsch ML, Roa J, Byquist AC, Crown A, Clifton DK, Hoffman GE, Steiner RA, Tena-Sempere M 2007 Sexual differentiation of Kiss1 gene expression in the brain of the rat. Endocrinology 148:1774-1783

83. Goodman RL, Porter KL, Connors JM, Hileman SM 2013 Neurokinin B (NKB) and the NKB receptor agonist, senktide, act in the ovine arcuate nucleus to produce different patterns of LH release. Endocr Rev 34:

84. Estrada KM, Clay CM, Pompolo S, Smith JT, Clarke IJ 2006 Elevated KiSS-1 expression in the arcuate nucleus prior to the cyclic preovulatory gonadotrophin-releasing hormone/lutenising hormone surge in the ewe suggests a stimulatory role for kisspeptin in oestrogen-positive feedback. Journal of Neuroendocrinology 18:806-809

85. Smith JT, Clay CM, Caraty A, Clarke IJ 2007 KiSS-1 messenger ribonucleic acid expression in the hypothalamus of the ewe is regulated by sex steroids and season. Endocrinology 148:11501157

86. Hoffman GE, Le WW, Franceschini I, Caraty A, Advis JP 2011 Expression of fos and in vivo median eminence release of LHRH identifies an active role for preoptic area kisspeptin neurons in synchronized surges of LH and LHRH in the ewe. Endocrinology 152:214-222

87. Smith JT, Coolen LM, Kriegsfeld LJ, Sari IP, Jaafarzadehshirazi MR, Maltby M, Bateman K, Goodman RL, Tilbrook AJ, Ubuka T, Bentley GE, Clarke IJ, Lehman MN 2008

Variation in kisspeptin and RFamide-related peptide (RFRP) expression and terminal connections to gonadotropin-releasing hormone neurons in the brain: a novel medium for seasonal breeding in the sheep. Endocrinology 149:5770-5782

88. Maggio JE 1988 Tachykinins. Annu Rev Neurosci 11:13-28

89. Nakanishi S 1986 Structure and regulation of the preprotachykinin gene. Trends in Neurosciences 9:41-44

90. Almeida TA, Rojo J, Nieto PM, Pinto FM, Hernandez M, Martin JD, Candenas ML 2004 Tachykinins and tachykinin receptors: structure and activity relationships. Curr Med Chem 11:2045-2081 
91. TAKAHASHI K, TANAKA A, HARA M, Nakanishi S 1992 The primary structure and gene organization of human substance $\mathrm{P}$ and neuromedin K receptors. European Journal of Biochemistry 204:1025-1033

92. Linden DR, Reutter MA, McCarson KE, Seybold VS 2000 Time-dependent changes in neurokinin(3) receptors and tachykinins during adjuvant-induced peripheral inflammation in the rat. Neuroscience 98:801-811

93. Pennefather JN, Lecci A, Candenas ML, Patak E, Pinto FM, Maggi CA 2004 Tachykinins and tachykinin receptors: a growing family. Life Sci 74:1445-1463

94. Regoli D, Boudon A, Fauchere JL 1994 Receptors and antagonists for substance P and related peptides. Pharmacol Rev 46:551-599

95. Wormser U, Laufer R, Hart Y, Chorev M, Gilon C, Selinger Z 1986 Highly selective agonists for substance P receptor subtypes. EMBO J 5:2805-2808

96. Chawla MK, Gutierrez GM, Young WS, III, McMullen NT, Rance NE 1997 Localization of neurons expressing substance $\mathrm{P}$ and neurokinin $\mathrm{B}$ gene transcripts in the human hypothalamus and basal forebrain. J Comp Neurol 384:429-442

97. Rance NE, Young WS, III 1991 Hypertrophy and increased gene expression of neurons containing neurokinin-B and substance-P messenger ribonucleic acids in the hypothalami of postmenopausal women. Endocrinology 128:2239-2247

98. Topaloglu AK, Reimann F, Guclu M, Yalin AS, Kotan LD, Porter KM, Serin A, Mungan NO, Cook JR, Ozbek MN, Imamoglu S, Akalin NS, Yuksel B, O'Rahilly S, Semple RK 2009 TAC3 and TACR3 mutations in familial hypogonadotropic hypogonadism reveal a key role for Neurokinin B in the central control of reproduction. Nat Genet 41:354-358

99. Gianetti E, Tusset C, Noel SD, Au MG, Dwyer AA, Hughes VA, Abreu AP, Carroll J, Trarbach E, Silveira LF, Costa EM, de Mendonca BB, de CM, Lofrano A, Hall JE, Bolu E, Ozata M, Quinton R, Amory JK, Stewart SE, Arlt W, Cole TR, Crowley WF, Kaiser UB, Latronico AC, Seminara SB 2010 TAC3/TACR3 mutations reveal preferential activation of gonadotropin-releasing hormone release by neurokinin B in neonatal life followed by reversal in adulthood. J Clin Endocrinol Metab 95:2857-2867

100. Young J, Bouligand J, Francou B, Raffin-Sanson ML, Gaillez S, Jeanpierre M, Grynberg M, Kamenicky P, Chanson P, Brailly-Tabard S, Guiochon-Mantel A 2010 TAC3 and TACR3 defects cause hypothalamic congenital hypogonadotropic hypogonadism in humans. $\mathrm{J}$ Clin Endocrinol Metab 95:2287-2295

101. Young J, George JT, Tello JA, Francou B, Bouligand J, Guiochon-Mantel A, BraillyTabard S, Anderson RA, Millar RP 2013 Kisspeptin restores pulsatile LH secretion in patients with neurokinin B signaling deficiencies: physiological, pathophysiological and therapeutic implications. Neuroendocrinology 97:193-202

102. Duarte CR, Schutz B, Zimmer A 2006 Incongruent pattern of neurokinin B expression in rat and mouse brains. Cell Tissue Res 323:43-51 
103. Lucas LR, Hurley DL, Krause JE, Harlan RE 1992 Localization of the tachykinin neurokinin B precursor peptide in rat brain by immunocytochemistry and in situ hybridization. Neuroscience 51:317-345

104. Marksteiner J, Sperk G, Krause JE 1992 Distribution of neurons expressing neurokinin B in the rat brain: immunohistochemistry and in situ hybridization. J Comp Neurol 317:341-356

105. Krajewski SJ, Burke MC, Anderson MJ, McMullen NT, Rance NE 2010 Forebrain projections of arcuate neurokinin B neurons demonstrated by anterograde tract-tracing and monosodium glutamate lesions in the rat. Neuroscience 166:680-697

106. Merchenthaler I, Maderdrut JL, O'Harte F, Conlon JM 1992 Localization of neurokinin B in the central nervous system of the rat. Peptides 13:815-829

107. Rance NE, Bruce TR 1994 Neurokinin B gene expression is increased in the arcuate nucleus of ovariectomized rats. Neuroendocrinology 60:337-345

108. Sandoval-Guzman T, Rance NE 2004 Central injection of senktide, an NK3 receptor agonist, or neuropeptide $\mathrm{Y}$ inhibits LH secretion and induces different patterns of Fos expression in the rat hypothalamus. Brain Res 1026:307-312

109. Garcia-Galiano D, van Ingen SD, Leon S, Krajnc-Franken MA, Manfredi-Lozano M, Romero-Ruiz A, Navarro VM, Gaytan F, van Noort PI, Pinilla L, Blomenrohr M, TenaSempere M 2012 Kisspeptin signaling is indispensable for neurokinin B, but not glutamate, stimulation of gonadotropin secretion in mice. Endocrinology 153:316-328

110. Navarro VM, Gottsch ML, Wu M, Garcia-Galiano D, Hobbs SJ, Bosch MA, Pinilla L, Clifton DK, Dearth A, Ronnekleiv OK, Braun RE, Palmiter RD, Tena-Sempere M, Alreja M, Steiner RA 2011 Regulation of NKB pathways and their roles in the control of Kiss1 neurons in the arcuate nucleus of the male mouse. Endocrinology 152:4265-4275

111. Kinsey-Jones JS, Grachev P, Li XF, Lin YS, Milligan SR, Lightman SL, O'Byrne KT 2012 The inhibitory effects of neurokinin B on GnRH pulse generator frequency in the female rat. Endocrinology 153:307-315

112. Navarro VM, Castellano JM, McConkey SM, Pineda R, Ruiz-Pino F, Pinilla L, Clifton DK, Tena-Sempere M, Steiner RA 2011 Interactions between kisspeptin and neurokinin B in the control of GnRH secretion in the female rat. Am J Physiol Endocrinol Metab 300:E202-E210

113. Kung TT, Crawley Y, Jones H, Luo B, Gilchrest H, Greenfeder S, Anthes JC, Lira S, Wiekowski M, Cook DN, Hey JA, Egan RW, Chapman RW 2004 Tachykinin NK3-receptor deficiency does not inhibit pulmonary eosinophilia in allergic mice. Pharmacol Res 50:611-615

114. Yang JJ, Caligioni CS, Chan YM, Seminara SB 2012 Uncovering novel reproductive defects in neurokinin B receptor null mice: closing the gap between mice and men. Endocrinology 153:1498-1508

115. Pillon D, Caraty A, Fabre-Nys C, Bruneau G 2003 Short-term effect of oestradiol on neurokinin B mRNA expression in the infundibular nucleus of ewes. J Neuroendocrinol 15:749753 
116. Nestor CC, Briscoe AM, Davis SM, Valent M, Goodman RL, Hileman SM 2012 Evidence of a role for kisspeptin and neurokinin B in puberty of female sheep. Endocrinology 153:2756-2765

117. Billings HJ, Connors JM, Altman SN, Hileman SM, Holaskova I, Lehman MN, McManus CJ, Nestor CC, Jacobs BH, Goodman RL 2010 Neurokinin B acts via the neurokinin-3 receptor in the retrochiasmatic area to stimulate luteinizing hormone secretion in sheep. Endocrinology 151:3836-3846

118. Sakamoto K, Murata K, Wakabayashi Y, Yayou K, Ohkura S, Takeuchi Y, Mori Y, Okamura H 2012 Central administration of neurokinin B activates kisspeptin/NKB neurons in the arcuate nucleus and stimulates luteinizing hormone secretion in ewes during the non-breeding season. J Reprod Dev 58:700-706

119. Amstalden M, Coolen LM, Hemmerle AM, Billings HJ, Connors JM, Goodman RL, Lehman MN 2010 Neurokinin 3 receptor immunoreactivity in the septal region, preoptic area and hypothalamus of the female sheep: colocalisation in neurokinin B cells of the arcuate nucleus but not in gonadotrophin-releasing hormone neurones. J Neuroendocrinol 22:1-12

120. Krajewski SJ, Anderson MJ, Iles-Shih L, Chen KJ, Urbanski HF, Rance NE 2005 Morphologic evidence that neurokinin B modulates gonadotropin-releasing hormone secretion via neurokinin 3 receptors in the rat median eminence. J Comp Neurol 489:372-386

121. Todman MG, Han SK, Herbison AE 2005 Profiling neurotransmitter receptor expression in mouse gonadotropin-releasing hormone neurons using green fluorescent protein-promoter transgenics and microarrays. Neuroscience 132:703-712

122. Nagatani S, Tsukamura H, Murahashi K, Maeda KI 1996 A rapid suppressive effect of estrogen in the paraventricular nucleus on pulsatile LH release in fasting-ovariectomized rats. J Neuroendocrinol 8:267-273

123. Cox BM, Opheim KE, Teschemacher H, Goldstein A 1975 A peptide-like substance from pituitary that acts like morphine. 2. Purification and properties. Life Sci 16:1777-1782

124. Goldstein A, Tachibana S, Lowney LI, Hunkapiller M, Hood L 1979 Dynorphin-(1-13), an extraordinarily potent opioid peptide. Proc Natl Acad Sci U S A 76:6666-6670

125. Lowney LI, Gentleman SB, Goldstein A 1979 A pituitary endorphin with novel properties. Life Sci 24:2377-2384

126. Simerly RB, Carr AM, Zee MC, Lorang D 1996 Ovarian steroid regulation of estrogen and progesterone receptor messenger ribonucleic acid in the anteroventral periventricular nucleus of the rat. J Neuroendocrinol 8:45-56

127. Foradori CD, Coolen LM, Fitzgerald ME, Skinner DC, Goodman RL, Lehman MN 2002 Colocalization of progesterone receptors in parvicellular dynorphin neurons of the ovine preoptic area and hypothalamus. Endocrinology 143:4366-4374

128. Foradori CD, Goodman RL, Adams VL, Valent M, Lehman MN 2005 Progesterone increases dynorphin a concentrations in cerebrospinal fluid and preprodynorphin messenger ribonucleic Acid levels in a subset of dynorphin neurons in the sheep. Endocrinology 146:1835-1842 
129. Dufourny L, Skinner DC 2002 Progesterone receptor, estrogen receptor alpha, and the type II glucocorticoid receptor are coexpressed in the same neurons of the ovine preoptic area and arcuate nucleus: a triple immunolabeling study. Biol Reprod 67:1605-1612

130. Chavkin C, James IF, Goldstein A 1982 Dynorphin is a specific endogenous ligand of the kappa opioid receptor. Science 215:413-415

131. Raynor K, Kong H, Chen Y, Yasuda K, Yu L, Bell GI, Reisine T 1994 Pharmacological characterization of the cloned kappa-, delta-, and mu-opioid receptors. Mol Pharmacol 45:330334

132. Goodman RL, Coolen LM, Anderson GM, Hardy SL, Valent M, Connors JM, Fitzgerald ME, Lehman MN 2004 Evidence that dynorphin plays a major role in mediating progesterone negative feedback on gonadotropin-releasing hormone neurons in sheep. Endocrinology 145:2959-2967

133. Sannella MI, Petersen SL 1997 Dual label in situ hybridization studies provide evidence that luteinizing hormone-releasing hormone neurons do not synthesize messenger ribonucleic acid for mu, kappa, or delta opiate receptors. Endocrinology 138:1667-1672

134. Mitchell V, Prevot V, Jennes L, Aubert JP, Croix D, Beauvillain JC 1997 Presence of mu and kappa opioid receptor mRNAs in galanin but not in GnRH neurons in the female rat. Neuroreport $8: 3167-3172$

135. Maggi R, Pimpinelli F, Martini L, Piva F 1995 Characterization of functional opioid delta receptors in a luteinizing hormone-releasing hormone-producing neuronal cell line. Endocrinology 136:289-295

136. Leadem CA, Yagenova SV 1987 Effects of specific activation of mu-, delta- and kappa-opioid receptors on the secretion of luteinizing hormone and prolactin in the ovariectomized rat. Neuroendocrinology 45:109-117

137. Walsh JP, Clarke IJ 1996 Effects of central administration of highly selective opioid mu-, deltaand kappa-receptor agonists on plasma luteinizing hormone (LH), prolactin, and the estrogeninduced LH surge in ovariectomized ewes. Endocrinology 137:3640-3648

138. Walsh JP, Clarke IJ 1998 Blockade of the oestrogen-induced luteinizing hormone surge in ovariectomized ewes by a highly selective opioid mu-receptor agonist: evidence for site of action. Neuroendocrinology 67:164-170

139. Currie WD, Ravindra J, Kingsbury DL, Rawlings NC 1992 Independence of progesterone blockade of the luteinizing hormone surge in ewes from opioid activity at naloxone-sensitive receptors. J Reprod Fertil 95:249-255

140. Richter TA, Spackman DS, Robinson JE, Dye S, Harris TG, Skinner DC, Evans NP 2001 Role of endogenous opioid peptides in mediating progesterone-induced disruption of the activation and transmission stages of the GnRH surge induction process. Endocrinology $142: 5212-5219$

141. Smith MJ, Gallo RV 1997 The effect of blockade of kappa-opioid receptors in the medial preoptic area on the luteinizing hormone surge in the proestrous rat. Brain Res 768:111-119 
142. Zhang Q, Gallo RV 2002 Effect of prodynorphin-derived opioid peptides on the ovulatory luteinizing hormone surge in the proestrous rat. Endocrine 18:27-32

143. Zhang Q, McCoy JM, Gallo RV 2002 Further studies on possible dynorphin involvement in the ovulatory luteinizing hormone surge in the proestrous rat. Endocrine 18:231-238

144. Whisnant SC, Havern RL, Goodman RL 1991 Endogenous opioid suppression of luteinizing hormone pulse frequency and amplitude in the ewe: hypothalamic sites of action.

Neuroendocrinology 54:587-593

145. Yang K, Haynes NB, Lamming GE, Brooks AN 1988 Ovarian steroid hormone involvement in endogenous opioid modulation of LH secretion in mature ewes during the breeding and nonbreeding seasons. J Reprod Fertil 83:129-139

146. Gallo RV 1980 Neuroendocrine regulation of pulsatile luteinizing hormone release in the rat. Neuroendocrinology 30:122-131

147. Panerai AE, Petraglia F, Sacerdote P, Genazzani AR 1985 Mainly mu-opiate receptors are involved in luteinizing hormone and prolactin secretion. Endocrinology 117:1096-1099

148. Ruka KA, Burger LL, Moenter SM 2013 Regulation of Arcuate Neurons Coexpressing Kisspeptin, Neurokinin B, and Dynorphin by Modulators of Neurokinin 3 and kappa-Opioid Receptors in Adult Male Mice. Endocrinology 154:2761-2771

149. Mostari P, Ieda N, Deura C, Minabe S, Yamada S, Uenoyama Y, Maeda K, Tsukamura H 2013 dynorphin-kappa opioid receptor signaling partly mediates estrogen negative feedback effect on LH pulses in female rats. J Reprod Dev 59:266-272

150. Ciofi P, Leroy D, Tramu G 2006 Sexual dimorphism in the organization of the rat hypothalamic infundibular area. Neuroscience 141:1731-1745

151. Dahl SK, Amstalden M, Coolen L, Fitzgerald M, Lehman M 2009 Dynorphin immunoreactive fibers contact GnRH neurons in the human hypothalamus. Reprod Sci 16:781787

152. Ramaswamy S, Guerriero KA, Gibbs RB, Plant TM 2008 Structural interactions between kisspeptin and GnRH neurons in the mediobasal hypothalamus of the male rhesus monkey (Macaca mulatta) as revealed by double immunofluorescence and confocal microscopy. Endocrinology 149:4387-4395

153. Wakabayashi Y, Yamamura T, Sakamoto K, Mori Y, Okamura H 2013 Electrophysiological and morphological evidence for synchronized GnRH pulse generator activity among Kisspeptin/neurokinin B/dynorphin A (KNDy) neurons in goats. J Reprod Dev 59:40-48

154. Grachev P, Li XF, Lin YS, Hu MH, Elsamani L, Paterson SJ, Millar RP, Lightman SL, O'Byrne KT 2012 GPR54-dependent stimulation of luteinizing hormone secretion by neurokinin B in prepubertal rats. PLoS One 7:e44344 
155. Ramaswamy S, Seminara SB, Plant TM 2011 Evidence from the agonadal juvenile male rhesus monkey (Macaca mulatta) for the view that the action of neurokinin B to trigger gonadotropinreleasing hormone release is upstream from the kisspeptin receptor. Neuroendocrinology 94:237245

156. Liu X, Lee K, Herbison AE 2008 Kisspeptin excites gonadotropin-releasing hormone neurons through a phospholipase $\mathrm{C} /$ calcium-dependent pathway regulating multiple ion channels. Endocrinology 149:4605-4614

157. Goodman RL, Hileman SM, Nestor CC, Porter KL, Connors JM, Hardy SL, Millar RP, Cernea M, Coolen LM, Lehman MN 2013 Kisspeptin, neurokinin B, and dynorphin act in the arcuate nucleus to control activity of the GnRH pulse generator in ewes. Endocrinology

158. Scanlan N, Dufourny L, Skinner DC 2003 Somatostatin-14 neurons in the ovine hypothalamus: colocalization with estrogen receptor alpha and somatostatin-28(1-12) immunoreactivity, and activation in response to estradiol. Biol Reprod 69:1318-1324

159. Pillon D, Caraty A, Fabre-Nys C, Lomet D, Cateau M, Bruneau G 2004 Regulation by estradiol of hypothalamic somatostatin gene expression: possible involvement of somatostatin in the control of luteinizing hormone secretion in the ewe. Biol Reprod 71:38-44

160. Clarke IJ, Pompolo S, Scott CJ, Rawson JA, Caddy D, Jakubowska AE, Pereira AM 2001 Cells of the arcuate nucleus and ventromedial nucleus of the ovariectomized ewe that respond to oestrogen: a study using Fos immunohistochemistry. J Neuroendocrinol 13:934-941

161. Rawson JA, Scott CJ, Pereira A, Jakubowska A, Clarke IJ 2001 Noradrenergic projections from the A1 field to the preoptic area in the brain of the ewe and Fos responses to oestrogen in the A1 cells. J Neuroendocrinol 13:129-138

162. Domanski E, Chomicka LK, Ostrowska A, Gajewska A, Mateusiak K 1991 Release of luteinizing hormone-releasing hormone, beta-endorphin and noradrenaline by the nucleus infundibularis/median eminence during periovulatory period in the sheep. Neuroendocrinology 54:151-158

163. Jackson GL 1977 Effect of adrenergic blocking drugs on secretion of luteinizing hormone in the ovariectomized ewe. Biol Reprod 16:543-548 


\section{CHAPTER 2}

\section{KNDY (KISSPEPTIN/NEUROKININ B/DYNORPHIN) NEURONS ARE ACTIVATED DURING BOTH PULSATILE AND SURGE SECRETION OF LH IN THE EWE}

This chapter was published in Endocrinology. Merkley, C.M., Porter, K.L., Coolen, L.M., Hileman, S.M., Billings, H.J., Drews, S., Goodman, R.L., Lehman, M.N. (2012). KNDy (Kisspeptin/Neurokinin B/Dynorphin) neurons are activated during both pulsatile and surge secretion of LH in the ewe. Endocrinology, 153(11): 5406-5414. Copyright 2012, The Endocrine Society. 


\begin{abstract}
KNDy (kisspeptin/neurokinin B/dynorphin) neurons of the arcuate nucleus (ARC) appear to mediate the negative feedback actions of estradiol and are thought to be key regulators of pulsatile LH secretion. In the ewe, KNDy neurons may also be involved with the positive feedback actions of estradiol $\left(\mathrm{E}_{2}\right)$ to induce the LH surge, but the role of kisspeptin neurons in the preoptic area (POA) remains unclear. The goal of this study was to identify which population(s) of kisspeptin neurons is (are) activated during the LH surge and in response to the removal of $E_{2}$-negative feedback, using Fos as an index of neuronal activation. Dual-label immunocytochemistry for kisspeptin and Fos was performed on sections containing the ARC and POA from ewes during the luteal phase of the estrous cycle, or before or after onset of the LH surge (experiment 1), and from ovary-intact, short-term (24h) and long-term (>30 d) ovariectomized (OVX) ewes in anestrus (experiment 2). The percentage of kisspeptin neurons expressing Fos in both the ARC and POA was significantly higher during the LH surge. In contrast, the percentage of kisspeptin/Fos colocalization was significantly increased in the ARC, but not the POA, after both short- and long-term $\mathrm{E}_{2}$ withdrawal. Thus, POA kisspeptin neurons in the sheep are activated during, and appear to contribute to, $\mathrm{E}_{2}$-positive feedback, whereas ARC kisspeptin (KNDy) neurons are activated during both surge and pulsatile modes of secretion and likely play a role in mediating both positive and negative feedback actions of $E_{2}$ on $\mathrm{GnRH}$ secretion in the ewe.
\end{abstract}




\section{Introduction}

Although the importance of gonadotropin-releasing hormone $(\mathrm{GnRH})$ in reproduction is well known, identification of the pathways through which estradiol $\left(E_{2}\right)$ regulates $\mathrm{GnRH}$ release remains an area of continuing investigation. Ovarian steroids exert negative feedback on GnRH/LH secretion throughout the luteal and early follicular phase of the estrous cycle (1). During the breeding season of ewes, $E_{2}$ serves to inhibit LH pulse amplitude while progesterone inhibits pulse frequency $(1,2)$; however, during anestrus (non-breeding season), $\mathrm{E}_{2}$ inhibits LH pulse frequency (3). In contrast to these inhibitory effects, the preovulatory GnRH/LH surge that occurs at the end of the follicular phase is induced by high levels of $E_{2}$ secreted from preovulatory follicles (4). Estrogen receptor- $\alpha$ (ER $\left.\alpha\right)$ is the key receptor in mediating regulation of $\mathrm{GnRH}$ by $\mathrm{E}_{2}$ (5). Because few, if any, GnRH neurons express ER $\alpha$ (6), the feedback actions of $E_{2}$ must occur via other neurons, and recent work points to kisspeptin neurons as playing a key role in this function. Importantly, most kisspeptin neurons express ER $\alpha$ (7) and can directly interact with GnRH neurons, 90\% of which express the kisspeptin receptor (8-10).

Kisspeptin, a member of the RF-amide family of neuropeptides, binds to its receptor, GPR54 $(11,12)$, and stimulates LH release in humans $(13)$ as well as in mice $(14)$, rats $(15,16)$, sheep $(17)$, and primates (18). A mutation in GPR54 causes hypogonadotropic hypogonadism in humans $(19,20)$, indicating the importance of the kisspeptin-GPR54 interaction in controlling sexual maturation and reproduction. Kisspeptin has now been identified as a key regulator of GnRH and LH secretion and has been proposed to mediate both negative and positive feedback actions of $E_{2}(21,22)$.

Two anatomically distinct kisspeptin populations exist in rodents. Those in the anteroventral periventricular nucleus (AVPV) have been proposed to mediate the $\mathrm{E}_{2}$-induced GnRH/LH surge $(23,24)$, while kisspeptin neurons in the arcuate nucleus (ARC) are thought to be responsible for $\mathrm{E}_{2}$-induced inhibition of episodic GnRH/LH secretion (21, 24-26). Sheep do not have a distinct AVPV, but kisspeptin neurons are evident in both the preoptic area (POA) and ARC, with some anatomical differences between the two populations. Almost all kisspeptin neurons in the ARC coexpress dynorphin and neurokinin B and, hence, are referred to as KNDy neurons (27). More than $90 \%$ of these neurons 
receive input from other KNDy neurons, thus forming an interconnected, reciprocal network with one another (28-30). POA kisspeptin neurons in sheep do not exhibit colocalization with dynorphin or neurokinin $\mathrm{B}$, and do not exhibit the same degree of reciprocal connections with each other as seen among KNDy neurons. There also may be functional differences between these two kisspeptin-containing neural populations. The effects of $\mathrm{E}_{2}$ removal (22) and replacement $(10,22)$ on Kiss 1 mRNA expression implicate ARC kisspeptin neurons as important mediators of $E_{2}$-negative feedback. However, the role of both POA and ARC kisspeptin neurons in the preovulatory LH surge remains unclear. During late follicular phase, elevated Kiss 1 mRNA expression has been observed in both the POA and some regions of the ARC (10). However, studies using Fos to analyze neuronal activation of kisspeptin neurons have been inconclusive $(10,31)$. The purpose of this study was to determine which population(s) of kisspeptin neurons are activated during the $\mathrm{LH}$ surge and in response to removal of $\mathrm{E}_{2}$-negative feedback, using Fos as an index of neural activity. Because anatomical subsets of ARC kisspeptin neurons have been implicated in the surge (10), and to assess the possibility that different ARC kisspeptin neurons might be dedicated to surge and tonic GnRH secretion, we analyzed Fos expression in rostral, middle, and caudal portions of the ARC, as has been done in previous work (10).

\section{Materials and Methods}

\section{Animals}

Adult blackface ewes were maintained under ambient conditions in an open barn with free access to food and water. Three to five days before any experimental procedures, ewes were moved to an indoor facility with controlled photoperiod simulating natural outdoor day length. In this facility, they had free access to water and a mineral lick and were fed a pelleted maintenance diet daily. Estrous behavior was

determined using vasectomized rams. Blood samples $(3-5 \mathrm{ml})$ were taken by jugular venipuncture, placed into heparinized tubes, and plasma collected and stored at -20 C. Ewes used for experiment 1 were killed during the breeding season (Oct.-Feb.), and ewes used in experiment 2 were killed during the nonbreeding season (May through July). All experimental procedures involving animals were approved by 
the West Virginia University Animal Care and Use Committee, and followed the National Institutes of Health guidelines for animal research.

\section{Animal Protocol}

Experiment 1. Which kisspeptin neurons are activated during the preovulatory LH surge?

To collect tissue from ewes at specific times of the estrous cycle, their cycles were synchronized with im injections $(10 \mathrm{mg})$ of prostaglandin $\mathrm{F}_{2 \alpha}\left(\mathrm{PGF}_{2 \alpha}\right.$; Lutalyse; Upjohn, Kalamazoo, $\left.\mathrm{MI}\right)$ to induce regression of the corpus luteum. Once cycles were synchronized, brain tissue was collected on d 9-10 of the luteal phase $(\mathrm{n}=4)$ or $\mathrm{PGF}_{2 \alpha}$ was again injected and two controlled internal drug releasing (CIDR) devices were inserted to maintain luteal phase progesterone concentrations (32). Ten days later, the CIDRs were removed and blood samples were collected every $4 \mathrm{~h}$ starting $12 \mathrm{~h}$ after CIDR removal until perfusion. Tissue was collected $4 \mathrm{~h}$ after onset of estrous behavior and, based on LH concentrations, animals were classified into pre-surge $(n=11)$ and surge $(n=5)$ groups. One ewe included in the surge group was estrous-synchronized with only $\mathrm{PGF}_{2 \alpha}$ (i.e., CIDRs omitted) and was killed during a clear LH surge.

\section{Experiment 2. Which kisspeptin neurons respond to removal of $E_{2}$ negative feedback?}

This experiment was performed in anestrus, when $\mathrm{E}_{2}$ is the only ovarian steroid inhibiting GnRH pulse frequency $(2,3)$. Bilateral ovariectomies were performed via midventral laparotomy using sterile procedures on ten anaesthetized (isofluorane) ewes as previously described (33). Tissue from the shortterm OVX group $(\mathrm{n}=5)$ was collected at $24 \mathrm{~h}$ post-OVX, and tissue from the long-term OVX group ( $\mathrm{n}=5)$ was collected at least 1 month post-OVX. Tissue from ovary-intact anestrous ewes $(n=5)$ was also collected. Blood samples were collected every $12 \mathrm{~min}$ for $4 \mathrm{~h}$ just before tissue collection in all three groups to determine LH pulse patterns. 


\section{Tissue Collection}

Tissue collection and processing was performed as previously described (27). Ewes were euthanized via an iv overdose of sodium pentobarbital ( $\sim 2 \mathrm{~g}$ in $7 \mathrm{ml}$ saline; Sigma, St. Louis, MO) after two iv injections of heparin (25,000 U), $10 \mathrm{~min}$ before and immediately before pentobarbitol. The head was removed and perfused through both carotid arteries with 6 liters of 4\% paraformaldehyde containing 10 $\mathrm{U} / \mathrm{ml}$ heparin and sodium nitrate. After perfusion, brains were removed, and POA/hypothalamic tissue was dissected out. The tissue was then infiltrated with $30 \%$ sucrose, and coronal sections (50 $\mu \mathrm{m}$ thick) were cut on a freezing microtome and stored at $-20 \mathrm{C}$ in cryoprotectant for later processing.

\section{Assays}

LH was measured in duplicate aliquots of 50-200 $\mu 1$ of plasma, using a previously validated RIA (33), and expressed in terms of NIH-LH-S12. The minimal detectable concentration of LH in these assays average $0.077 \mathrm{ng} /$ tube; inter and intraassay coefficients of variation were $3.8 \%$ and $1.7 \%$, respectively. Circulating progesterone was measured in duplicate aliquots of $150 \mu 1$ plasma using a commercially available solid- phase RIA kit (Coat-A-Count $\mathrm{P}_{4}$, Diagnostic Products, Corp., Los Angeles, CA), which has been validated in sheep (34) to confirm stage of cycle.

\section{Immunocytochemistry for kisspeptin and Fos}

All immunohistochemistry was carried out on free-floating sections at room temperature, and sections were washed with $0.1 \mathrm{~m}$ PBS between incubations. For all experiments, tissue sections were first incubated in hydrogen peroxide (10 min in PBS; EMD Chemicals, Inc., Gibbstown, NJ) to occupy endogenous peroxidase sites, followed by incubation in a solution containing $20 \%$ normal goat serum (Jackson Immunoresearch Laboratories, Inc., Gibbstown, NJ) in PBS containing 0.4\% Triton X-100 (Fisher Scientific, Pittsburgh, PA) for $1 \mathrm{~h}$ to minimize nonspecific binding.

A dual-label immunoperoxidase procedure was then performed on a series of every fifth POA and ARC section in each animal. Fos-ir nuclei were detected using a rabbit polyclonal antibody against c-Fos 
(1:1,000 (Exp. 1) or 1:2500 (Exp. 2); sc-52, Santa Cruz Biotechnology, Inc.) for $17 \mathrm{hr}$, followed by incubation with biotinylated goat anti-rabbit IgG (1:500; Jackson Immunoresearch Laboratories, Inc.) for $1 \mathrm{~h}$ and avidin-biotin-horseradish peroxidase complex (ABC-elite; 1:500; Vector Laboratories, Burglingame, CA) for $1 \mathrm{~h}$. Labelling was visualized using nickel-enhanced diaminobenzidine (Sigma) as the chromogen, producing a black/purple reaction product that is limited to the nucleus. For detection of kisspeptin, sections were incubated for $17 \mathrm{~h}$ in polyclonal rabbit anti-kisspeptin-10 serum $(1: 100,000$ (Exp. 1) or 1:50,000 (Exp. 2); \#564, gift from A. Caraty, Université Tours, Nouzilly, France) for 17 h, an antibody that has been previously validated for use in sheep tissue $(27,35)$. Following incubation in primary antiserum, tissue was labelled with biotinylated goat anti-rabbit IgG (1:500; Jackson Immunoresearch Laboratories, Inc.) and ABC-elite (1:500; Vector Laboratories) for $1 \mathrm{~h}$ each. Kisspeptin was visualized using diaminobenzidine as the chromogen, which produced a brown reaction product within the cytoplasm. Sections were then mounted onto Superfrost slides, air-dried, dehydrated, and coverslipped using Depex (DPX; Electron Microscopy Sciences, Hatfield, PA).

For each ewe, the numbers of single kisspeptin and dual-labeled kisspeptin/Fos cells were counted under bright field illumination in the POA (three sections per ewe) and ARC (three sections per rostral, middle and caudal subdivisions in each ewe) by an independent observer. POA sections selected for analysis were those at the rostral-caudal level of, and just posterior, to the organum vasculosum of the lamina terminalis. For selection of ARC sections, the rostral ARC was defined as that level of the nucleus anterior to the appearance of the tubero-infundibular sulcus; the middle ARC was at the level of the tubero-infundibular sulcus; and the caudal ARC was at the level of the mammillary recess of the third ventricle. To assess the possibility of functionally distinct subsets of ARC kisspeptin neurons, we analyzed all three rostral-caudal levels of the ARC to account for the possibility that there may be regional differences within the ARC in the functional activation of kisspeptin cells during the surge. To assist with analysis, bright-field images were captured using a cooled charge-coupled device camera (Microfire, Optronics, Goleta, CA) attached to a Leica microscope (DM5000B, Leica Microsystems, Weztler, Germany) and Neurolucida software (MicroBrightfield, Inc., Williston, VT) with fixed camera 
settings for all animals; a transparent grid was then placed over the printed images to aid with counting. A cell was considered dual labeled when brown kisspeptin-positive cytoplasm was seen to surround a black Fos-positive nucleus in the same plane of focus, and the percentage of dual labeling was calculated as the total number of dual-labeled cells divided by the total number of kisspeptin-positive cells.

\section{Statistical Analysis}

The mean number of single-labeled kisspeptin and dual-labeled kisspeptin/Fos cells in each region (POA and rostral, middle and caudal subdivisions of the ARC) were counted for each animal, and the percentage of kisspeptin cells containing Fos was calculated. The mean and SEM were calculated for each group, and one-way ANOVAs were conducted within each region between luteal, pre-surge, and surge groups (Exp. 1), and intact, $1 \mathrm{~d}$ OVX, and chronic OVX groups (Exp. 2). Post hoc analyses of all pairwise comparisons were computed using Tukey tests to account for the problem of multiple comparisons. In experiment 2, LH pulses were identified using standard criteria (1) and statistically significant differences in mean LH concentrations analyzed by one-way ANOVA and in LH pulse frequencies by Kruskal-Wallis one-way ANOVA on ranks.

\section{Results}

Experiment 1: which kisspeptin neurons are activated during the preovulatory LH surge?

As expected, mean LH concentrations at perfusion in surge animals increased by seven and five fold from luteal and pre-surge groups, respectively $(P<0.05)$ (Figure 1B).

Anatomically, kisspeptin perikarya were localized to the POA and ARC, with the greatest numbers of cell bodies seen within the middle ARC and the fewest number of cell bodies in the POA (Figure 2A). In the middle ARC, pre-surge animals had significantly greater numbers of kisspeptin cells compared with luteal phase animals, but not surge animals $(P<0.05$; Figure 2A). There were no significant effects of stage of cycle on kisspeptin cell numbers in any other area. In addition, we noted that labeling of 
kisspeptin-ir fibers appeared more intense in the pre-surge animals compared with the surge animals (Figure 2C).

Surge animals showed a significantly greater percentage of kisspeptin cells colocalizing Fos compared to both luteal and pre-surge animals throughout the rostral, middle and caudal divisions of the ARC $(P<0.05$; Figure 2B) and in the POA $(P<0.05$; Figure 2B). The percentage of kisspeptin cells that colocalized Fos in each region of surge animals was consistent, ranging from 44 to $61 \%$ in the both ARC (rostral, middle, caudal) and POA, but because there were far fewer kisspeptin cells in the POA, the absolute number of Fos-expressing cells in this region was lower than in the ARC (Figure3). Examples of single- and dual-labeled kisspeptin neurons in the ARC and POA are shown in Figure 2C, and their anatomical location is shown in Figure 3. The percentage of colocalization of kisspeptin with Fos did not differ between luteal and pre-surge animals in any area (Figure 2B).

\section{Experiment 2: which kisspeptin neurons respond to removal of $E_{2}$ negative feedback?}

As expected, LH pulse frequency increased after OVX from $1.0 \pm 0.3$ pulse $/ 4 \mathrm{~h}$ in intact ewes to $2.0 \pm$ 0.3 pulses/4 h $1 \mathrm{~d}$ after OVX. Frequency further increased to $4.0 \pm 0.4$ pulses $/ 4 \mathrm{~h}$ in chronically OVX animals (Figure 4A). Mean LH concentrations also increased three and nine fold in 1-d OVX and longterm OVX ewes, respectively (Figure 4B).

In the ovary-intact anestrous ewes, ARC kisspeptin cells were most numerous in the caudal ARC, with moderate numbers present in the middle ARC and POA (Figure 5A). After more than 1 month after OVX, kisspeptin cell numbers significantly increased in both the rostral and middle ARC. A similar pattern of increased cell numbers was also observed in the 1-d post-OVX ewes $(P<0.05$; Figure 5A). There were no significant effects of OVX on kisspeptin cell numbers in the POA.

$\mathrm{E}_{2}$ withdrawal significantly increased the percentage of ARC kisspeptin cells co-localizing Fos in the rostral, middle, and caudal ARC after $24 \mathrm{~h}$ post-OVX, and this colocalization was further increased in chronically OVX ewes $(P<0.05$; Figure 5B). No significant changes in the percentage of kisspeptin/Fos 
colocalization were observed in the POA at either time point, and this percentage of colocalization remained low $(<10 \%)$.

\section{Discussion}

Using a well-defined surge model, we observed that kisspeptin neurons of both the ARC and POA are activated after the onset of the preovulatory surge, indicating a role for both populations in $\mathrm{E}_{2}$ positive feedback in the ewe. In contrast, we observed that ARC, but not POA, kisspeptin neurons are activated following the withdrawal of $\mathrm{E}_{2}$, suggesting that only ARC kisspeptin neurons are likely important mediators of $\mathrm{E}_{2}$-negative feedback.

Several lines of evidence support the involvement of both ARC and POA kisspeptin neurons in $\mathrm{E}_{2}$-positive feedback in the ewe. First, in the late follicular phase, Kiss $1 \mathrm{mRNA}$ has been shown to increase in the middle and caudal ARC, as well as in the POA $(10,36)$. Second, there was also an increase in kisspeptin protein in the ARC during this time (10). Third, $\mathrm{E}_{2}$ treatment of OVX ewes increased kisspeptin mRNA and protein expression in the POA (35). Leading up to the surge, we observed an increase in kisspeptin cell number and fiber intensity in the middle ARC, which may reflect an increased sequestration of the peptide in the cell body as a result of the up-regulated Kiss 1 mRNA (10, 36).

Although the aforementioned data show that Kiss 1 mRNA and kisspeptin protein are up-regulated prior to the surge, our data show that soon after the onset of the preovulatory surge, kisspeptin cells are transcriptionally activated in both the ARC and POA. Interestingly, Smith et al. (10) failed to show an increase in Fos expression within POA kisspeptin cells $1 \mathrm{hr}$ after a surge-inducing injection of $\mathrm{E}_{2}$ to $\mathrm{OVX}$ ewes. In their paper, they propose that the activation of these neurons may occur outside of the time window they chose to study (10), which could be consistent with our results. In contrast to the findings of Smith et al. (10), a recent study using ovary-intact ewes observed Fos expression in POA, but not ARC, kisspeptin neurons during the preovulatory LH surge (31). These authors suggested that the contrasting findings to previous work (10) might be due to different animal models (ovary-intact $v s$. OVX). Our data confirm the activation of POA kisspeptin at the time of the LH surge reported by Hoffman et al. (31), but 
we also observed increased Fos expression in the ARC population. One possible explanation for this discrepancy is that the chronic guide tubes traversing the ARC (used to monitor GnRH in the median eminence) in the animals used by Hoffman et al. (31) may have disrupted activation of ARC kisspeptin neurons. Another possible explanation is that different antibodies for detection of Fos were used in these two studies, suggesting the possibility that differences in observed Fos may be due to a different antibody sensitivity (Smith et al. used the same antibody we did). Despite this discrepancy, most mRNA studies in the ewe are consistent with the idea that both ARC (KNDy) and POA kisspeptin neuronal populations participate in mediating $\mathrm{E}_{2}$ positive feedback in this species $(10,36)$.

In the second experiment, we observed a significant increase in both numbers of kisspeptinpositive cells and their activation (as measured by Fos) in the ARC of long-term OVX ewes. Kisspeptin cell numbers and activation were also elevated, coincident with increased LH release, as early as $24 \mathrm{~h}$ post-OVX, demonstrating the rapid response of ARC kisspeptin neurons to the removal of $\mathrm{E}_{2}$. No changes were observed in the POA kisspeptin neurons at either time point. Thus we suggest that ARC, not POA, kisspeptin neurons mediate $\mathrm{E}_{2}$ negative feedback and therefore are likely key regulators of episodic LH secretion. These data confirm previous studies which found that chronic removal of $\mathrm{E}_{2}$ by $\mathrm{OVX}$ increased (22), and chronic $\mathrm{E}_{2}$-treatment decreased, both Kiss 1 mRNA expression $(10,22)$ and number of kisspeptin-ir cells in the ovine ARC (10) during the breeding season. Our data extend these observations by demonstrating an early increase in both kisspeptin cell number and Fos colocalization following OVX. Similar to the work in sheep, studies in both humans and rodents also point to ARC kisspeptin neurons as mediators of $E_{2}$ negative feedback. Postmenopausal women show both hypertrophy of kisspeptin neurons and increased kisspeptin gene expression in the infundibular nucleus (37), suggesting that kisspeptin in this area is normally held in check by steroid negative feedback. In rodents, OVX increases, and $\mathrm{E}_{2}$ treatment decreases, Kiss 1 expression in the ARC (26), but there is no evidence that OVX increases Fos expression in these neurons (38).

In comparing kisspeptin populations involved in the positive and negative feedback actions of $\mathrm{E}_{2}$ among species in which this question has been addressed, two consistent patterns emerge: 1) the more 
rostral population (POA in sheep, AVPV and associated areas in rodents) is dedicated to the initiation of the LH surge, and 2) the ARC kisspeptin population participates in the negative feedback control of pulsatile LH secretion. In sheep, between 40 and $60 \%$ of POA kisspeptin neurons are activated during the surge (this study and (31)). This roughly corresponds with the $\sim 50 \%$ of POA kisspeptin-ir neurons that express $\operatorname{ER} \alpha$ (7), but whether this population overlaps with the activated kisspeptin cells observed here remains to be determined. These neurons may be stimulated directly by $E_{2}$, but this seems unlikely because in the ewe the mediobasal hypothalamus, not the POA is the site at which $\mathrm{E}_{2}$ acts to induce an LH surge (39). Alternatively, these cells may be indirectly regulated, and subsequently activated, by steroid-sensitive afferents. In rodents, $\mathrm{E}_{2}$ increases both kisspeptin expression (26) and Fos-colocalization with kisspeptin in the AVPV $(24,38,40)$. Interestingly, the percentage (ranging from 30-60\%) of rostral kisspeptin neurons activated at the time of the surge in rodents $(24,38,40)$ is similar to that in sheep. Almost all of these neurons in rodents contain ER $\alpha$ (26) and evidence suggests that $E_{2}$ positive feedback in rodents occurs directly on these kisspeptin neurons (41). Studies that examined the more rostral kisspeptin population observed relatively low levels of kisspeptin/Fos colocalization in the absence of an LH surge in both sheep $(10,31)$ and rodents $(24,38,40)$, again consistent with this population being dedicated to the LH surge.

It is also generally accepted that the ARC kisspeptin (KNDy) neurons in rodents and sheep mediate the negative feedback actions of $\mathrm{E}_{2}$. It has also been proposed that they drive episodic GnRH secretion (42-44), but there may be some species differences in their activation. As already noted, OVX increased Fos expression in these neurons in sheep (this study), but apparently not in rodents (38). Moreover, in both current experiments, we observed that approximately $20 \%$ of KNDy neurons contain Fos during the follicular phase or during anestrous, even though LH secretion is at a basal level. This finding is apparently inconsistent with that of Hoffman et al. (31), who reported only about 5\% of ARC kisspeptin neurons are activated in early follicular phase ewes (31). As discussed above, this may reflect differences in the antibodies used to detect Fos immunoreactivity or that Hoffman et al. (31) used tissue from ewes with chronic guide tubes traversing the ARC. Smith et al. (10) observed approximately 15\% 
ARC kisspeptin/Fos colocalization during the luteal phase of ewes, which increased to about $35 \%$ during the late follicular phase. The relatively high level of Fos expression in ovine KNDy neurons, compared with POA kisspeptin neurons, during basal secretion of LH is consistent with the hypothesis that KNDy neurons are important in tonic secretion of GnRH (42-44). In contrast, colocalization of kisspeptin and Fos in the ARC of rats is less than 5\% on diestrus 2 of the cycle (24).

The one major difference between KNDy neurons in sheep and rodents is that they appear to participate in the LH surge in the former, but not the latter. Two of three studies observed high levels of Fos expression in KNDy neurons associated with the surge in sheep, whereas, with one exception (23), this has not been observed in rodents (24). As noted above, this difference is consistent with evidence that the positive feedback action of $E_{2}$ occurs in the mediobasal hypothalamus in the sheep, and in the region of the AVPV in rodents (41). Interestingly, while almost all ovine KNDy neurons express ER $\alpha$ in the ewe (7), only $45-60 \%$ are activated during the surge. What remains unclear from these data is if this activation is due to heterogeneity in the ARC population, so that different subsets of neurons govern positive and negative feedback, or alternatively, if the same neurons govern positive and negative feedback, but are not activated at the same time. Moenter et al. (45), showed that approximately $40 \%$ of GnRH neurons were activated during the surge, and postulated that different neurons may be activated over time throughout the GnRH surge in order to maintain high levels of GnRH release. The high level of Fos expression in KNDy neurons of OVX ewes (70-90\%, Figure 3.4) suggests that the same neurons are involved in both $\mathrm{E}_{2}$-positive and negative feedback. Reciprocal connections between KNDy neurons, that are postulated to play an important role in episodic GnRH secretion (42-44), may be responsible for the high percentage of activated KNDy neurons after OVX. If this is the case, the lower percentage of KNDy neurons containing Fos during the LH surge, may suggest a less important role for this reciprocal innervation. This proposal is consistent with the changes in multi-unit electrical activity associated with LH pulses at the time of the LH surge in monkeys, rats and goats (46-48). Fos induction in most neurons is thought to be a consequence of glutamate release and its postsynaptic action, and it is interesting in this regard that a majority of KNDy neurons in the sheep colocalize glutamatergic markers (49), including expression 
within terminals that form reciprocal KNDy-KNDy contacts (50). Thus, release of glutamate from KNDy presynaptic terminals may be partly responsible for the Fos induction seen during increased pulsatile activity.

In summary, these data demonstrate that both the ARC (KNDy) and POA kisspeptin neurons are activated during, and therefore likely play an important role in, the GnRH/LH surge in ewes. In contrast, only ARC kisspeptin neurons had increased kisspeptin expression and activation following $\mathrm{E}_{2}$ removal, indicating the key role of ARC kisspeptin in the negative feedback regulation of episodic GnRH secretion by $\mathrm{E}_{2}$. Whether the same or different subsets of ARC kisspeptin neurons are activated during surge and tonic GnRH secretion remains to be determined. 


\section{References}

1. Goodman RL, Karsch FJ 1980 Pulsatile secretion of LH: Differential suppression by ovarian steroids. Endocrinology 107:1286-1290

2. Karsch FJ 1987 Central Actions of Ovarian Steroids in the Feedback Regulation of Pulsatile Secretion of Luteinizing Hormone. Annual Review of Physiology 49:365-382

3. Goodman RL, Bittman EL, Foster D, Karsch FJ 1982 Alterations in the control of LH pulse frequency underlie the seasonal variation in estradiol negative feedback in the ewe. Biology of Reproduction 27:580-589

4. Herbison AE 1998 Multimodal Influence of Estrogen upon Gonadotropin-Releasing Hormone Neurons. Endocr Rev 19:302-330

5. Wintermantel TM, Campbell RE, Porteous R, Bock D, Gröne H-J, Todman MG, Korach KS, Greiner E, Pérez CA, Schütz G, Herbison AE 2006 Definition of Estrogen Receptor Pathway Critical for Estrogen Positive Feedback to Gonadotropin-Releasing Hormone Neurons and Fertility. Neuron 52:271-280

6. Lehman MN, Ebling FJ, Moenter SM, Karsch FJ 1993 Distribution of estrogen receptorimmunoreactive cells in the sheep brain. Endocrinology 133:876-886

7. Franceschini I, Lomet D, Cateau M, Delsol G, Tillet Y, Caraty A 2006 Kisspeptin immunoreactive cells of the ovine preoptic area and arcuate nucleus co-express estrogen receptor alpha. Neuroscience Letters 401:225-230

8. Han S-K, Gottsch ML, Lee KJ, Popa SM, Smith JT, Jakawich SK, Clifton DK, Steiner RA, Herbison AE 2005 Activation of Gonadotropin-Releasing Hormone Neurons by Kisspeptin as a Neuroendocrine Switch for the Onset of Puberty. J Neurosci 25:11349-11356

9. Irwig MS, Fraley GS, Smith JT, Acohido BV, Popa SM, Cunningham MJ, Gottsch ML, Clifton DK, Steiner RA 2004 Kisspeptin Activation of Gonadotropin Releasing Hormone Neurons and Regulation of KiSS-1 mRNA in the Male Rat. Neuroendocrinology 80:264-272

10. Smith JT, Li Q, Pereira A, Clarke IJ 2009 Kisspeptin Neurons in the Ovine Arcuate Nucleus and Preoptic Area Are Involved in the Preovulatory Luteinizing Hormone Surge. Endocrinology $150: 5530-5538$

11. Kotani M, Detheux M, Vandenbogaerde A, Communi D, Vanderwinden J-M, Le Poul E, Brézillon S, Tyldesley R, Suarez-Huerta N, Vandeput F, Blanpain Cd, Schiffmann SN, Vassart G, Parmentier M 2001 The Metastasis Suppressor Gene KiSS-1 Encodes Kisspeptins, the Natural Ligands of the Orphan G Protein-coupled Receptor GPR54. Journal of Biological Chemistry 276:34631-34636

12. Ohtaki T, Shintani Y, Honda S, Matsumoto H, Hori A, Kanehashi K, Terao Y, Kumano S, Takatsu Y, Masuda Y, Ishibashi Y, Watanabe T, Asada M, Yamada T, Suenaga M, Kitada C, Usuki S, Kurokawa T, Onda H, Nishimura O, Fujino M 2001 Metastasis suppressor gene KiSS-1 encodes peptide ligand of a G-protein-coupled receptor. Nature 411:613-617 
13. Dhillo WS, Chaudhri OB, Patterson M, Thompson EL, Murphy KG, Badman MK, McGowan BM, Amber V, Patel S, Ghatei MA, Bloom SR 2005 Kisspeptin-54 Stimulates the Hypothalamic-Pituitary Gonadal Axis in Human Males. J Clin Endocrinol Metab 90:6609-6615

14. Gottsch ML, Cunningham MJ, Smith JT, Popa SM, Acohido BV, Crowley WF, Seminara S, Clifton DK, Steiner RA 2004 A Role for Kisspeptins in the Regulation of Gonadotropin Secretion in the Mouse. Endocrinology 145:4073-4077

15. Matsui H, Takatsu Y, Kumano S, Matsumoto H, Ohtaki T 2004 Peripheral administration of metastin induces marked gonadotropin release and ovulation in the rat. Biochemical and Biophysical Research Communications 320:383-388

16. Thompson E, Patterson, M, Murphy, KG, Smith, KL, Dhillo, WS, Todd, JF, Ghatei, MA, Bloom, SR 2004 Central and Peripheral Administration of Kisspeptin-10 Stimulates the Hypothalamic-Pituitary-Gonadal Axis. Journal of Neuroendocrinology 16:850-858

17. Messager S, Chatzidaki EE, Ma D, Hendrick AG, Zahn D, Dixon J, Thresher RR, Malinge I, Lomet D, Carlton MBL, Colledge WH, Caraty A, Aparicio SAJR 2005 Kisspeptin directly stimulates gonadotropin-releasing hormone release via $\mathrm{G}$ protein-coupled receptor 54. Proceedings of the National Academy of Sciences of the United States of America 102:17611766

18. Shahab M, Mastronardi C, Seminara SB, Crowley WF, Ojeda SR, Plant TM 2005 Increased hypothalamic GPR54 signaling: A potential mechanism for initiation of puberty in primates. Proceedings of the National Academy of Sciences of the United States of America 102:21292134

19. de Roux N, Genin E, Carel J-C, Matsuda F, Chaussain J-L, Milgrom E 2003 Hypogonadotropic hypogonadism due to loss of function of the KiSS1-derived peptide receptor GPR54. Proceedings of the National Academy of Sciences of the United States of America 100:10972-10976

20. Seminara SB, Messager S, Chatzidaki EE, Thresher RR, Acierno JS, Jr., Shagoury JK, BoAbbas Y, Kuohung W, Schwinof KM, Hendrick AG, Zahn D, Dixon J, Kaiser UB, Slaugenhaupt SA, Gusella JF, O'Rahilly S, Carlton MBL, Crowley WF, Jr., Aparicio SAJR, Colledge WH 2003 The GPR54 Gene as a Regulator of Puberty. N Engl J Med 349:1614-1627

21. Dungan HM, Clifton DK, Steiner RA 2006 Minireview: Kisspeptin Neurons as Central Processors in the Regulation of Gonadotropin-Releasing Hormone Secretion. Endocrinology $147: 1154-1158$

22. Smith JT, Clay CM, Caraty A, Clarke IJ 2007 KiSS-1 Messenger Ribonucleic Acid Expression in the Hypothalamus of the Ewe Is Regulated by Sex Steroids and Season. Endocrinology 148:1150-1157

23. Kinoshita M, Tsukamura H, Adachi S, Matsui H, Uenoyama Y, Iwata K, Yamada S, Inoue K, Ohtaki T, Matsumoto H, Maeda K-I 2005 Involvement of Central Metastin in the Regulation of Preovulatory Luteinizing Hormone Surge and Estrous Cyclicity in Female Rats. Endocrinology 146:4431-4436 
24. Smith JT, Popa SM, Clifton DK, Hoffman GE, Steiner RA 2006 Kiss1 Neurons in the Forebrain as Central Processors for Generating the Preovulatory Luteinizing Hormone Surge. J Neurosci 26:6687-6694

25. Navarro VM, Castellano JM, Fernandez-Fernandez R, Tovar S, Roa J, Mayen A, Nogueiras R, Vazquez MJ, Barreiro ML, Magni P, Aguilar E, Dieguez C, Pinilla L, Tena-Sempere M 2005 Characterization of the Potent Luteinizing Hormone-Releasing Activity of KiSS-1 Peptide, the Natural Ligand of GPR54. Endocrinology 146:156-163

26. Smith JT, Cunningham MJ, Rissman EF, Clifton DK, Steiner RA 2005 Regulation of Kiss 1 Gene Expression in the Brain of the Female Mouse. Endocrinology 146:3686-3692

27. Goodman RL, Lehman MN, Smith JT, Coolen LM, de Oliveira CVR, Jafarzadehshirazi MR, Pereira A, Iqbal J, Caraty A, Ciofi P, Clarke IJ 2007 Kisspeptin Neurons in the Arcuate Nucleus of the Ewe Express Both Dynorphin A and Neurokinin B. Endocrinology 148:5752-5760

28. Burke M, Letts, PA, Krajewski, SJ, Rance, NE 2006 Coexpression of dynorphin and neurokinin B immunoreactivity in the rat hypothalamus: Morphologic evidence of interrelated function within the arcuate nucleus. The Journal of Comparative Neurology 498:712-726

29. Foradori CD, Coolen LM, Fitzgerald ME, Skinner DC, Goodman RL, Lehman MN 2002 Colocalization of Progesterone Receptors in Parvicellular Dynorphin Neurons of the Ovine Preoptic Area and Hypothalamus. Endocrinology 143:4366-4374

30. Krajewski SJ, Burke MC, Anderson MJ, McMullen NT, Rance NE 2010 Forebrain projections of arcuate neurokinin B neurons demonstrated by anterograde tract-tracing and monosodium glutamate lesions in the rat. Neuroscience 166:680-697

31. Hoffman GE, Le WW, Franceschini I, Caraty A, Advis JP 2011 Expression of Fos and in Vivo Median Eminence Release of LHRH Identifies an Active Role for Preoptic Area Kisspeptin Neurons in Synchronized Surges of LH and LHRH in the Ewe. Endocrinology 152:214-222

32. Van Cleef J, Karsch, F.J., Padmanabhan, V. 1998 Characterization of endocrine events during the periestrous period in sheep after estrous synchronization with controlled internal release (CIDR) device. Domestic Animal Endocrinology 15:23-34

33. Foradori CD, Goodman RL, Adams VL, Valent M, Lehman MN 2005 Progesterone Increases Dynorphin A Concentrations in Cerebrospinal Fluid and Preprodynorphin Messenger Ribonucleic Acid Levels in a Subset of Dynorphin Neurons in the Sheep. Endocrinology 146:1835-1842

34. Padmanabhan V, Evans, NP., Dahl, GE., McFadden, KL., Mauger, DT., Karsch, FJ. 1995 Evidence for short or ultrashort loop negative feedback of GnRH secretion. Neuroendocrinology $62: 242-258$

35. Smith JT, Coolen LM, Kriegsfeld LJ, Sari IP, Jaafarzadehshirazi MR, Maltby M, Bateman K, Goodman RL, Tilbrook AJ, Ubuka T, Bentley GE, Clarke IJ, Lehman MN 2008 Variation in Kisspeptin and RFamide-Related Peptide (RFRP) Expression and Terminal Connections to Gonadotropin-Releasing Hormone Neurons in the Brain: A Novel Medium for Seasonal Breeding in the Sheep. Endocrinology 149:5770-5782 
36. Estrada KM, Clay, C.M., Pompolo, S., Smith, J.T., Clarke, I.J. 2006 Elevated KiSS-1 Expression in the Arcuate Nucleus Prior to the Cyclic Preovulatory Gonadotrophin-Releasing Hormone/Lutenising Hormone Surge in the Ewe Suggests a Stimulatory Role for Kisspeptin in Oestrogen-Positive Feedback. Journal of Neuroendocrinology 18:806-809

37. Rometo AM, Krajewski SJ, Lou Voytko M, Rance NE 2007 Hypertrophy and Increased Kisspeptin Gene Expression in the Hypothalamic Infundibular Nucleus of Postmenopausal Women and Ovariectomized Monkeys. J Clin Endocrinol Metab 92:2744-2750

38. Adachi S, Yamada S, Takatsu Y, Matsui H, Kinoshita M, Takase K, Sugiura H, Ohtaki T, Matsumoto H, Uenoyama Y, Tsukamura H, Inoue K, Maeda K-I 2007 Involvement of Anteroventricular Periventricular Matastin/Kisspeptin Neurons in Estrogen Positive Feedback Action on Leutentizing Hormone Release in Female Rats. Journal of Reproduction and Development 53:367-378

39. Caraty A, Fabre-Nys C, Delaleu B, Locatelli A, Bruneau G, Karsch FJ, Herbison A 1998 Evidence That the Mediobasal Hypothalamus Is the Primary Site of Action of Estradiol in Inducing the Preovulatory Gonadotropin Releasing Hormone Surge in the Ewe. Endocrinology 139:1752-1760

40. Clarkson J, d'Anglemont de Tassigny X, Moreno AS, Colledge WH, Herbison AE 2008 Kisspeptin-GPR54 Signaling Is Essential for Preovulatory Gonadotropin-Releasing Hormone Neuron Activation and the Luteinizing Hormone Surge. J Neurosci 28:8691-8697

41. Herbison AE 2008 Estrogen positive feedback to gonadotropin-releasing hormone (GnRH) neurons in the rodent: The case for the rostral periventricular area of the third ventricle (RP3V). Brain Research Reviews 57:277-287

42. Lehman MN, Coolen LM, Goodman RL 2010 Minireview: Kisspeptin/Neurokinin B/Dynorphin (KNDy) Cells of the Arcuate Nucleus: A Central Node in the Control of Gonadotropin-Releasing Hormone Secretion. Endocrinology 151:3479-3489

43. Navarro VM, Gottsch ML, Chavkin C, Okamura H, Clifton DK, Steiner RA 2009 Regulation of Gonadotropin-Releasing Hormone Secretion by Kisspeptin/Dynorphin/Neurokinin B Neurons in the Arcuate Nucleus of the Mouse. J Neurosci 29:11859-11866

44. Rance NE, Krajewski SJ, Smith MA, Cholanian M, Dacks PA 2010 Neurokinin B and the hypothalamic regulation of reproduction. Brain Research 1364:116-128

45. Moenter SM, Karsch FJ, Lehman MN 1993 Fos expression during the estradiol-induced gonadotropin-releasing hormone $(\mathrm{GnRH})$ surge of the ewe: induction in $\mathrm{GnRH}$ and other neurons. Endocrinology 133:896-903

46. Nishihara M, Sano A, Kimura F 1994 Cessation of the electrical activity of gonadotropinreleasing hormone pulse generator during the steroid-induced surge of luteinizing hormone in the rat. Neuroendocrinology 59:513-519

47. O'Byrne KT, Thalabard J-C, Grosser PM, Wilson RC, Williams CL, Chen M-D, Ladendorf D, Hotchkiss J, Knobil E 1991 Radiotelemetric Monitoring of Hypothalamic GonadotropinReleasing Hormone Pulse Generator Activity Throughout the Menstrual Cycle of the Rhesus Monkey. Endocrinology 129:1207-1214 
48. Tanaka T, Ozawa T, Hoshino K, Mori Y 1995 Changes in the gonadotropin-releasing hormone pulse generator activity during the estrous cycle in the goat. Neuroendocrinology 62:553-561

49. Merkley CM, Coolen LM, Goodman RL, Lehman MN Colocalization of glutamate within kisspeptin cells and their projections onto GnRH neurons in the ewe. International Congress of Neuroendocrinology Abstract 2010, P2-10

50. Merkley CM, Coolen LM, Goodman RL, Lehman MN Evidence for Neuroplasticity in Synaptic Inputs to Arcuate Kisspeptin Cells and GnRH Neurons across the Ovine Estrous Cycle. Endocrine Reviews 32:P2-268 


\section{Figure 1}

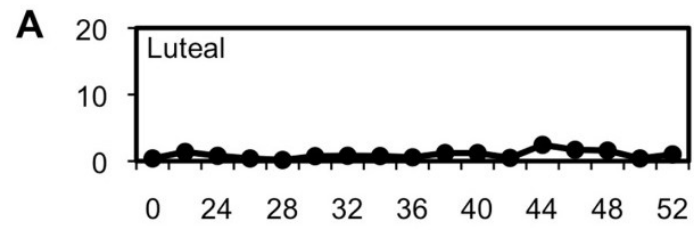

B
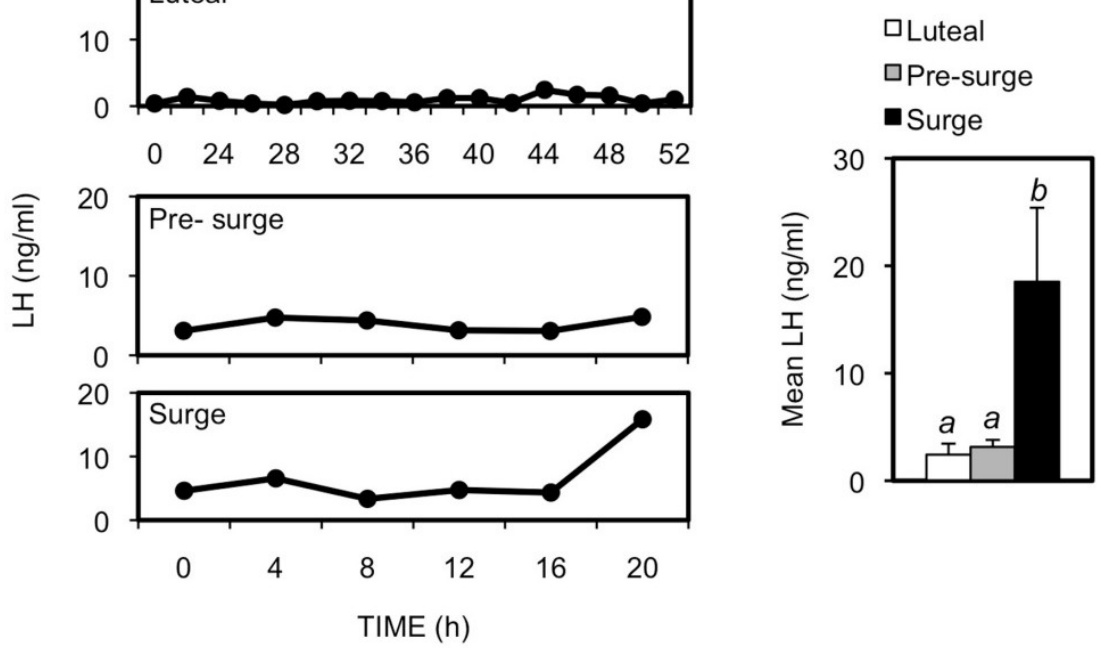

Figure 1. Luteinizing hormone (LH) in luteal, pre-surge and surge ovary-intact ewes. A, Representative LH profiles from ovary-intact luteal, pre-surge and surge ewes taken before perfusion. Note that on the y-axis of the presurge and surge LH profiles, time $=0$ represents $12 \mathrm{~h}$ after CIDR removal. B, Mean LH levels at perfusion were significantly higher in the surge group compared with both luteal and presurge groups. Letters (a and b) represent significant differences from other groups, $P<0.05$. Data are means $\pm \mathrm{SEM}$. 
Figure 2

A

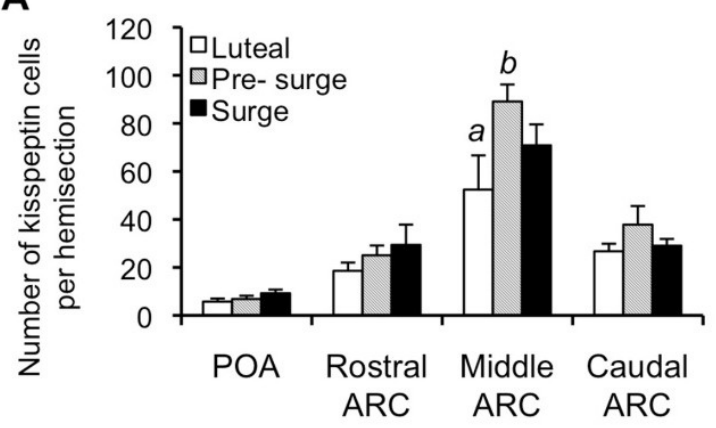

B

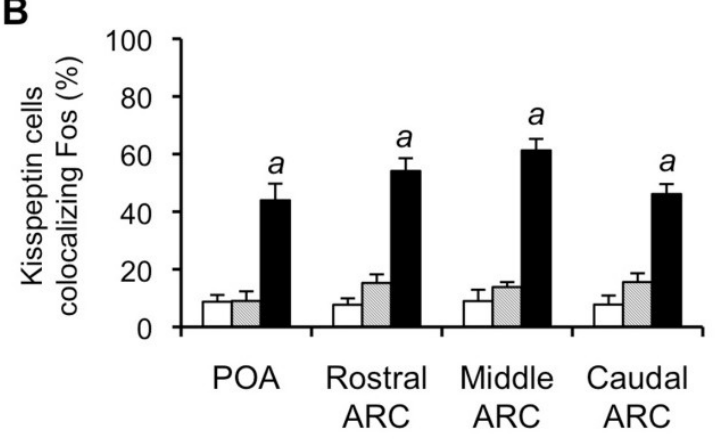

C
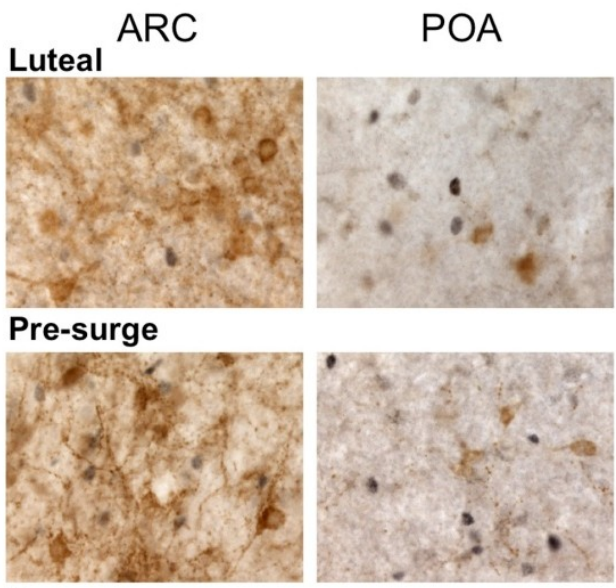

Surge
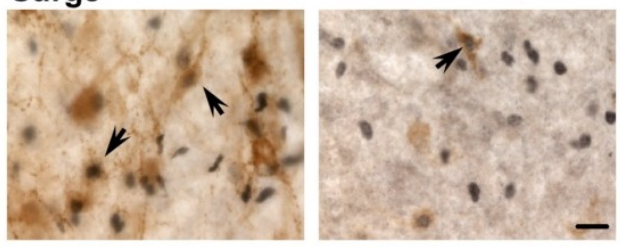

Figure 2. Kisspeptin cells in both the ARC and POA are activated during the LH surge. Kisspeptin cell number (A) and percent colocalization with Fos (B) in luteal, presurge and surge groups in the POA, and rostral, middle and caudal levels of the ARC. Letters (a, b, and c) represent significant differences between groups within the same area, $P<0.05$. $\mathrm{C}$, Sections immunestained for kisspeptin and Fos through the middle ARC (left column) and POA (right column) from luteal, pre-surge and surge animals. Arrows show examples of dual-labeled cells. Scale bar, $10 \mu \mathrm{m}$. 


\section{Figure 3}

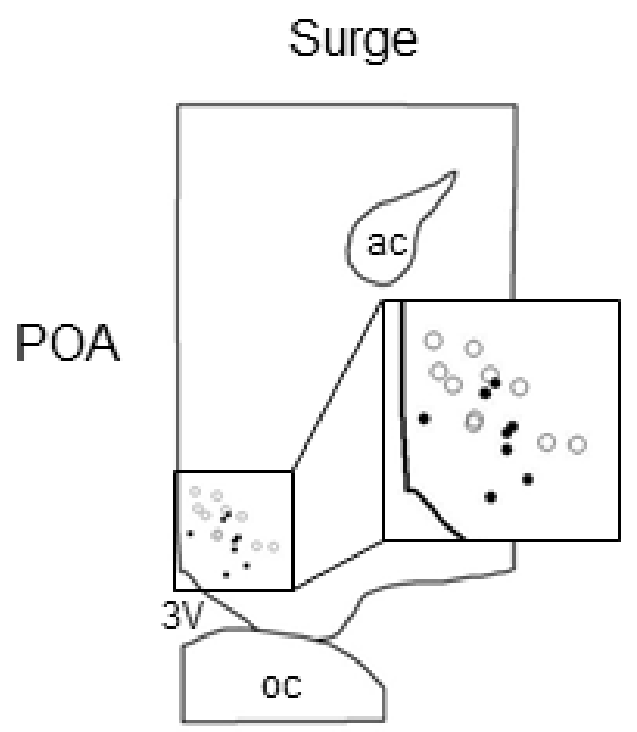

OVX
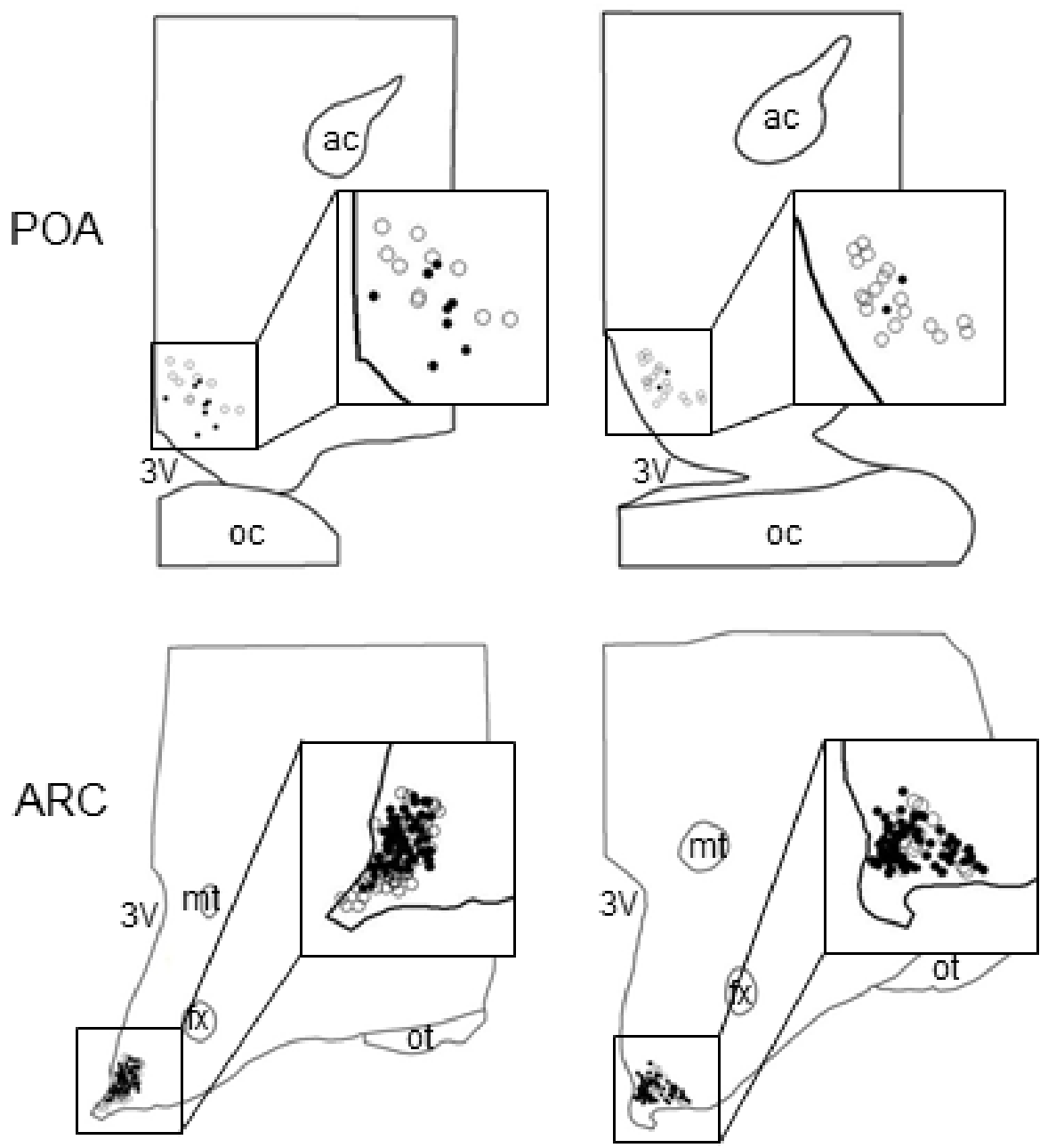

Figure 3. Camera lucida drawings of representative sections through the POA (top) and ARC (bottom) of sheep killed either during the LH surge (left) or $30 \mathrm{~d}$ after OVX (right). The location of single-labeled kisspeptin cells (open circles) and dual-labeled Fos/kisspeptin cells (black circles) are shown at low and high magnification in each of the drawings (boxed areas). ac, anterior commissure; $3 \mathrm{~V}$, third ventricle; fx, fornix; oc, optic chiasm; ot, optic tract; mt, mammillothalamic tract. 
Figure 4

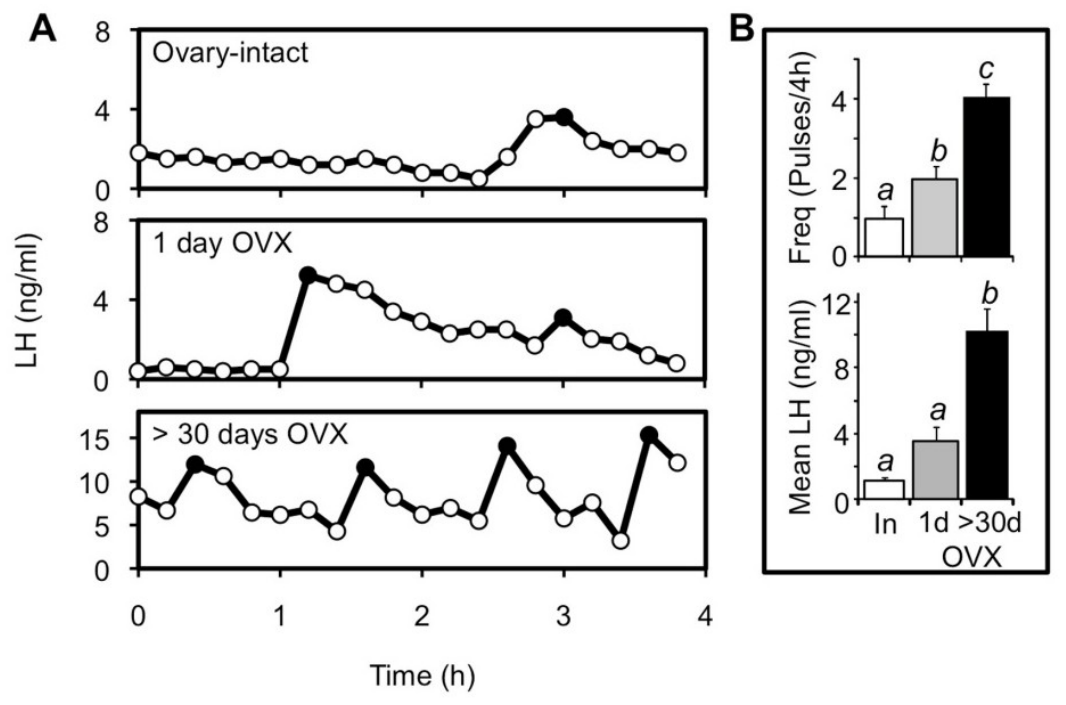

Figure 4. Luteinizing hormone (LH) in intact and OVX ewes. A, Representative LH profiles from ovary-intact, $1 \mathrm{~d}$ after OVX, and more than $30 \mathrm{~d}$ post-OVX ewes. Black circles indicate pulse peaks. Note different scale on y-axis for data from ewe OVX for more than $30 \mathrm{~d}$. B, Mean pulse frequency (top panel) and LH concentration (bottom panel) in each group of ewes. Letters $(\mathrm{a}, \mathrm{b}$, and $\mathrm{c})$ represent significant differences from other groups, $P<0.05$. Data are means \pm SEM. 


\section{Figure 5}

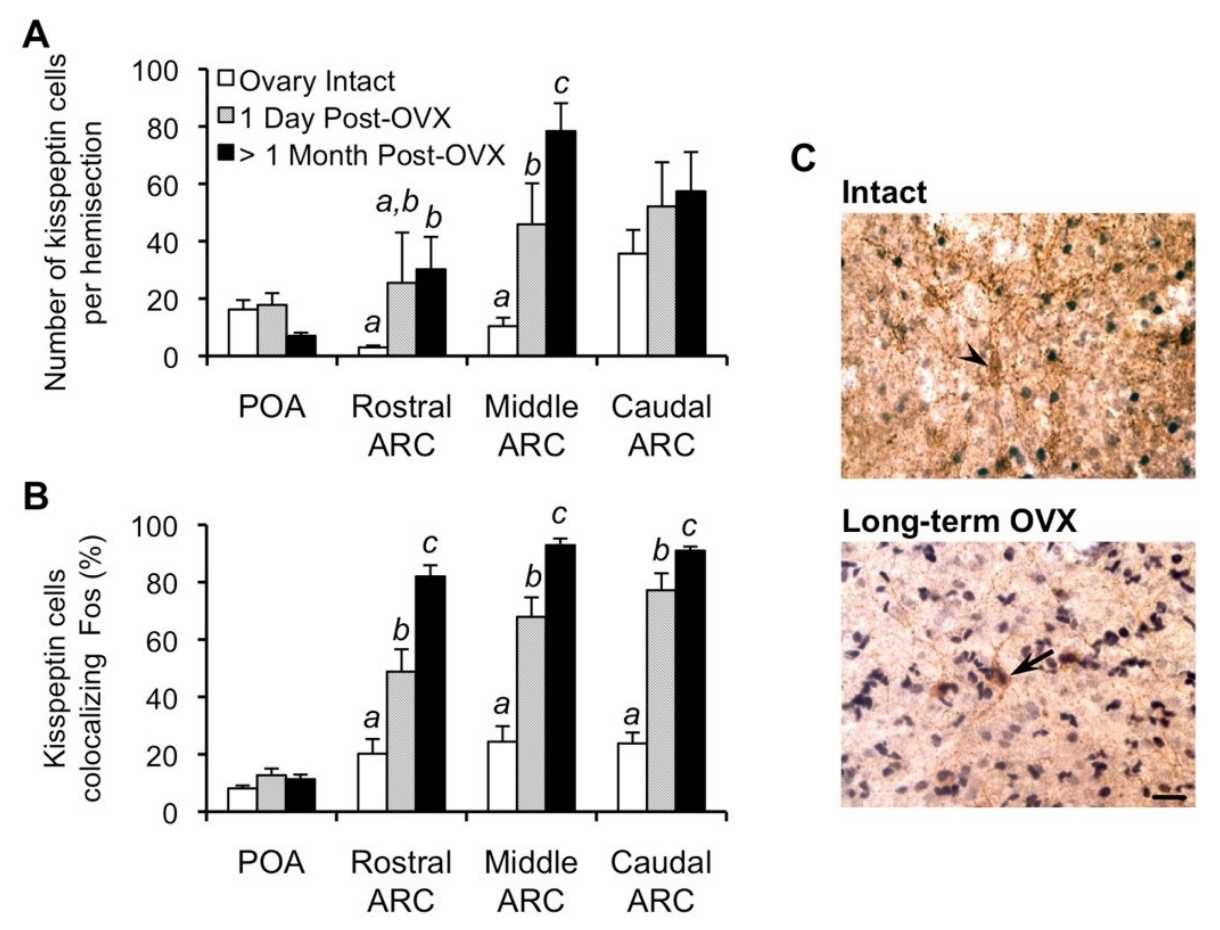

Figure 5. Ovariectomy increases activation of kisspeptin cells in the ARC, but not the POA. Kisspeptin cell number (A) and percent colocalization with Fos (B) in ovary-intact, 1 d postOVX, and more than 30 days post-OVX ewes in the POA and rostral, middle, and caudal sections of the ARC. Letters (a, b, and c) represent significant differences from each other within the same area, $P<0.05$. C, Sections immunostained for kisspeptin and Fos through the middle ARC in gonadal-intact and long-term ( $>30 \mathrm{~d})$ OVX ewes. Arrowhead and arrows indicate examples of single- and dual-labeled cells, respectively. Scale bar, $10 \mu \mathrm{m}$. 
CHAPTER 3

\section{NEUROKININ-3 RECEPTOR ACTIVATION IN THE RETROCHIASMATIC AREA IS ESSENTIAL FOR THE FULL PREOVULATORY LH SURGE IN EWES}

Katrina L. Porter, Stanley M. Hileman, Steven L. Hardy, Casey C Nestor, Michael N. Lehman, Robert L. Goodman

Department of Physiology and Pharmacology (K.L.P.; S.M.H.; S.L.H; C.C.N.; R.L.G.), West Virginia University, Morgantown, West Virginia 26506

Department of Neurobiology and Anatomical Sciences (M.N.L.), University of Mississippi Medical Center, Jackson, MS 39216

Running title: Retrochiasmatic NK3R activation and the LH surge 


\begin{abstract}
Neurokinin B (NKB) is essential for human reproduction and has been shown to stimulate LH secretion in non-rodent species, including sheep. Ewes highly express the neurokinin-3 receptor (NK3R) in the retrochiasmatic area $(\mathrm{RCh})$ and placement of senktide, an NK3R agonist, therein stimulates LH secretion that resembles an LH surge in ewes. In this study, we investigated the effects of the natural ligand, NKB, or senktide in the RCh and three other areas where NK3R is found in high abundance: the preoptic area (POA), paraventricular nucleus (PVN), and arcuate nucleus (ARC). Bilateral microimplants containing NKB had no effect on LH secretion when given in any of the four areas, while senktidecontaining microimplants induced a dramatic surge-like increase in LH when given in the RCh and POA. A relatively smaller, but significant, increase after senktide treatment was observed in the ARC. No effect was seen in the PVN. The possible role of POA and RCh NK3R activation in the LH surge was then tested by treating ewes with SB222200, an NK3R antagonist, in each area during an $\mathrm{E}_{2}$-induced LH surge. SB222200 in the RCh, but not in the POA, reduced LH surge amplitude compared to controls, indicating that NK3R activation in this region is essential for full expression of the preovulatory LH surge. Based on these data, we suggest that NKB actions in the RCh are an important component of the preovulatory LH surge in ewes.
\end{abstract}




\section{INTRODUCTION}

Although more than twenty years have passed since the initial study linking NKB to LH secretion in humans (1) and more recent evidence clearly demonstrated that NKB is critical for reproduction in humans (2), the details of how and where NKB acts to influence LH release remain largely unknown. Most work on NKB has focused on its possible roles in controlling tonic, episodic LH secretion. Low levels of tonic secretion of $\mathrm{GnRH} / \mathrm{LH}$ are maintained during the luteal phase and early follicular phase by the negative feedback actions of estradiol $\left(\mathrm{E}_{2}\right)$ and progesterone (3). However, these feedback actions of ovarian steroids on GnRH are likely indirect since GnRH neurons do not express progesterone receptors (PR) $(4,5)$ or ER $\alpha$ (6), the ER isoform responsible for regulating GnRH secretion (7). NKB neurons may participate in steroid negative feedback regulation of GnRH release because they highly express ER $\alpha$ (8).

Interest in $\mathrm{NKB}$ as a regulator of GnRH release began with the discovery that a subset of neurons coexpressing NKB and ER $\alpha$ in the infundibular nucleus undergo hypertrophy in postmenopausal women, indicating that $\mathrm{NKB}$ is under $\mathrm{E}_{2}$-negative feedback control (1). These investigators further postulated that this hypertrophy was indicative of increased activity and thus NKB may contribute to the menopauseassociated increase in $\mathrm{LH}$ release. Subsequent studies confirmed that $\mathrm{E}_{2}$ inhibits NKB as removal of steroid negative feedback via ovariectomy (OVX) increased NKB gene expression in the ARC of female monkeys $(9,10)$, sheep (11), rats $(12)$, and mice $(13,14)$, while $E_{2}$ treatment of OVX animals suppressed NKB gene expression in these same species $(10,12,14-17)$. Furthermore, stimulation of LH secretion by NKB or senktide, a neurokinin-3 receptor (NK3R) agonist, has been described in non-rodent species including adult sheep $(18,19)$, prepubertal ewes $(11)$, and prepubertal male monkeys $(20)$. In rodents, the effects of NKB or senktide on GnRH/LH secretion appear to be dependent on steroid milieu (21). Data consistently shows that NK3R agonists stimulate LH secretion in gonad-intact mice $(22,23)$ and rats $(21,24)$, but that they inhibit LH secretion in OVX mice $(14)$ and rats $(21,24)$. However the effects of $\mathrm{NK} 3 \mathrm{R}$ agonists in $\mathrm{OVX}+\mathrm{E}_{2}$ rodents lack consistency, with either inhibition or stimulation of LH release in rats $(21,24,25)$ and no effect in mice (14). 
While NKB is clearly an important regulator of LH secretion, it is unclear where NKB specifically acts to control GnRH release. The discovery that most ARC NKB neurons in ewes coexpress kisspeptin and dynorphin (thus named KNDy neurons) suggests that NKB closely interacts with kisspeptin (26), which is a potent stimulator of GnRH/LH secretion (27). More recently, NK3R was found to colocalize with a majority of NKB neurons in rats (28), mice (14), and sheep (29), while few or no GnRH neurons were found to express NK3R in rats (21) and sheep (29), respectively. In contrast, the vast majority of GnRH neurons express the kisspeptin receptor, Kiss 1r in both rodents $(30,31)$ and sheep (32), indicating that kisspeptin, but not NKB, directly affects GnRH neurons. These data, as well as others, have led to the hypothesis that NKB, acting via kisspeptin, is responsible for driving episodic LH secretion via a reciprocal KNDy neuron network while dynorphin acts as a brake to this system $(14,33,34)$.

Although most NKB studies to date have focused on control of tonic GnRH secretion, this peptide may also be involved in the GnRH/LH surge. Both injection of senktide in the third ventricle and placement of senktide-containing microimplants in the retrochiasmatic area $(\mathrm{RCh})$ of the hypothalamus significantly stimulate LH secretion in ewes, with the high LH levels and pattern of secretion more closely resembling an LH surge than tonic LH secretion (18). However, it is unclear whether NK3R agonists have similar effects in other areas of the hypothalamus or if endogenous NKB plays a role in the LH surge. Therefore, the aim of our first study was to determine in which hypothalamic areas NKB or the NK3R agonist, senktide, acts to stimulate LH secretion. NK3Rs are highly expressed in the ovine preoptic area (POA), paraventricular nucleus (PVN), RCh, and ARC (29). The aim of our second study was to determine whether activation of NK3R in senktide-responsive areas is necessary for a normal LH surge.

\section{METHODS}

Animals. All experiments used adult ewes of predominantly Suffolk breeding that were housed indoors under a controlled photoperiod simulating natural outdoor day length. Ewes were fed a pelleted alfalfa diet and provided free access to water and supplemental minerals. Breeding season experiments were 
performed from October to mid-February and anestrus experiments from May through August. For experiments in follicular phase ewes (Exps. 1 and 3), ovarian cycles were synchronized as previously described (18). Briefly, two intramuscular (im) injections of prostaglandin $\mathrm{F}_{2 \alpha}(5 \mathrm{mg} / \mathrm{mL}$, Luteolyse, Pharmacia \& Upjohn Co., NY, NY) were given $3 \mathrm{~h}$ apart, and this regimen was repeated seven days later. At this time two progesterone-containing controlled internal drug-releasing devices (CIDRs; Eazi-Breed, Pharmacia \& Upjohn, New York, NY) were inserted intravaginally to produce luteal phase levels of progesterone. Seven days later $\mathrm{PGF}_{2 \alpha}$ was again injected and CIDRs were removed. Experiments began $18 \mathrm{~h}$ later, during the early follicular phase. All procedures were approved by the West Virginia University Animal Care and Use Committee and conducted in accordance with NIH guidelines on the care and use of animals in research.

Surgeries. All surgeries were performed under sterile conditions using isofluorane anesthesia. Ewes were first anesthetized using a combination of ketamine and diazapem injected IV to facilitate insertion of a tracheal tube. Bilateral chronic 18-gauge guide cannulae were stereotaxically inserted into either the $\mathrm{RCh}$, POA, PVN or ARC as previously described (35). Ovariectomies were performed via midventral laparotomy (36). Ewes were treated with dexamethasone and penicillin pre- and post-operatively, and daily with analgesic (Banamine, Phoenix Pharmaceutical, St. Joseph, MO; $125 \mathrm{mg} / \mathrm{sheep}$ ) starting at the time of anesthesia to 5 days after surgery.

Experimental Approach. To determine whether the natural ligand NKB, the NK3R agonist senktide, or the NK3R antagonist SB222200 (all obtained from Tocris Bioscience, Ellisville, MO) altered LH secretion, we administered the drugs by microimplantation or microinjection into the RCh, POA, PVN, or ARC. Microimplants were constructed from 22-gauge stainless steel tubing and cut to extend to the tip of the guide cannulae for ARC experiments or $1.5 \mathrm{~mm}$ beyond the tip for the RCh, PVN, and POA. Our previous work showed that extending empty microimplants beyond the end of the guide tube within the ARC influenced LH release (37). Microimplants were filled by tamping 40 times in crystalline NKB, senktide, or SB222200. As a control, empty microimplants were used. For microinjections, needles were 
adjusted to a length that extended $1.5 \mathrm{~mm}$ beyond the tip of the guide cannulae. Senktide (10 pmol/300 $\mathrm{nL}$ sterile water) or sterile water alone was injected.

\section{Experiment 1A: Effect of NKB microimplants in the RCh, POA, PVN, or ARC on LH release in}

follicular phase ewes. Starting $18 \mathrm{~h}$ after CIDR removal, blood samples were collected by jugular venipuncture every $12 \mathrm{~min}$ for $24 \mathrm{~min}$ before and for $4 \mathrm{~h}$ after insertion of NKB-filled or empty microimplants. Samples were then taken every $30 \mathrm{~min}$ for an additional $4 \mathrm{~h}$, after which microimplants were removed, obturators replaced to occlude the guide cannulae, and two CIDRs inserted intravaginally. Seven days later, CIDRs were removed, PGF2 $\alpha$ was injected, and the treatment protocol repeated using a cross-over design so that ewes given NKB in the first replicate received empty microimplants during the second and vice versa.

Experiment 1B: Effect of senktide microinjection in the POA or PVN on LH release in follicular phase ewes. Because NKB was ineffective in Exp. 1A, we next tested whether senktide would act in the POA or PVN to increase LH secretion using these same animals; stimulation of LH release by local administration of senktide to the RCh and ARC had already been demonstrated in our earlier work $(18,37)$. Ovarian cycles were synchronized as described above and experiments were performed during the early follicular phase. Frequent blood samples (every $10 \mathrm{~min}$ ) were collected from each ewe before and after bilateral microinjections (within 2 min of each other) of vehicle or senktide (10 pmoles/side); treatments were randomized with $1 \mathrm{~h}$ of sampling between injections when vehicle was injected first, and $4 \mathrm{~h}$ between injections when senktide was given first. An increase in LH concentrations in response to senktide was determined by comparing the mean of the three samples following injection of senktide vs. vehicle.

Experiment 2: Effect of NKB or senktide in the RCh of anestrous ewes. The failure of NKB to stimulate LH secretion when placed within the RCh in Exp. 1 raised the possibility that actions of NKB and senktide might differ since our previous work showed that microimplants of senktide in the RCh stimulated LH secretion in follicular phase ewes (18). Therefore, we next directly compared the effects of 
these two NK3R agonists in the RCh of ovary-intact anestrous ewes. Anestrous ewes were previously shown to respond to RCh senktide treatment in a manner similar to follicular phase animals (18). Because the ewes were anovulatory, synchronization of ovarian cycles was not needed. Blood collection and treatment protocols were conducted as described in Experiment 1, except that three treatments were given: empty, NKB-containing, or senktide-containing microimplants administered in a random order, with $8 \mathrm{~d}$ between treatments.

\section{Experiment 3: Effect of senktide microimplants in the POA and ARC on LH release in follicular phase}

ewes. The protocol was the same as that used for Experiment 1, except that senktide-containing microimplants were used in place of NKB-containing microimplants and only the POA and ARC were targeted.

Experiment 4: Effect of SB222200 in the RCh or POA on the $E_{2}$-induced LH surge. Ewes underwent OVX in addition to neurosurgery for guide cannulae placement aimed at the RCh (in September) or POA (in January). At the time of OVX, one short $(1 \mathrm{~cm}) \mathrm{E}_{2}$-containing Silastic implant was inserted subcutaneously (s.c.) and two CIDRs were inserted intravaginally. CIDRs were removed 10-14 days later. Twenty-four hours post-CIDR removal, four long $(3 \mathrm{~cm}) \mathrm{E}_{2}$-containing Silastic implants were inserted s.c., to establish an artificial follicular phase and produce an LH surge (38). Either empty or SB222200containing microimplants were inserted into the RCh or POA just before insertion of the long $\mathrm{E}_{2}$ implants. Starting $8 \mathrm{~h}$ later, jugular blood samples were taken every $2 \mathrm{~h}$ for $24 \mathrm{~h}$ then continued every $4 \mathrm{~h}$ for an additional $12 \mathrm{~h}$. New SB222200-containing microimplants were inserted $24 \mathrm{~h}$ after original microimplants were inserted to maintain SB222200 delivery. At the conclusion of the sampling period, microimplants and the longer $E_{2}$ implants were removed. SB222200 powder was still visible in the lumen of the microimplants at removal. CIDRs were reinserted 3 days later to reestablish an artificial luteal phase. Ten days after CIDR insertion, CIDRs were removed and the experiment was repeated in crossover design so that each ewe received both control and SB222200 treatment. 
Tissue collection. One or two days after conclusion of the final blood sampling period in all experiments, ewes were euthanized via an overdose of sodium pentobarbital (8-12 $\mathrm{ml}$ of Euthasol; $390 \mathrm{mg}$ pentobarbital sodium/mL; Webster Veterinary, Devens MA). Two iv injections of heparin $(25,000 \mathrm{U})$ were given 10 minutes prior to, and immediately before, pentobarbital. The head was quickly removed and perfused via the carotid arteries with 6 liters of $4 \%$ paraformaldehyde in $0.1 \mathrm{M}$ phosphate buffer containing $0.1 \% \mathrm{NaNO}_{3}$. After perfusion, a block of tissue containing the POA and hypothalamus was dissected from the brain and stored in paraformaldehyde overnight at $4 \mathrm{C}$. The tissue was then infiltrated with $30 \%$ sucrose, and coronal sections ( $50 \mu \mathrm{m}$ thick) were cut on a freezing microtome and stored at -20 $\mathrm{C}$ in cryoprotectant. A series of every fifth section was mounted on slides and stained with cresyl violet to evaluate cannulae placement.

Assays. Using an RIA which has previously been validated in sheep (39), LH was measured in duplicate using 25-200 $\mu \mathrm{l}$ of plasma and expressed in terms of NIH-LH-S12. The minimal detectable concentration of LH in these assays averaged $0.10 \mathrm{ng} /$ tube; intra- and interassay coefficients of variation were $15.0 \%$ and $18.2 \%$, respectively. To confirm stage of the estrous cycle in ovary intact ewes, circulating progesterone was measured in duplicate aliquots of $150 \mu \mathrm{l}$ plasma using a commercially available solidphase RIA kit (Coat-A-Count Kit, Diagnostics Products Corporation, Los Angeles, CA), which has been validated in sheep (35). All follicular-phase ewes had plasma progesterone concentrations less than 0.3 $\mathrm{ng} / \mathrm{ml}$; intra- and interassay coefficients of variation were $2.3 \%$ and $1.2 \%$, respectively.

Statistical analysis. LH pulses were identified using established criteria $(3,40)$ for samples collected during the first $4 \mathrm{~h}$ of treatment in Exps. 1-3. Comparisons of LH pulse frequencies in these three experiments were accomplished using a Wilcoxin-Mann-Whitney test. Differences in mean LH concentrations (all samples), LH pulse amplitude (peak minus previous nadir), and pulse nadir (lowest value preceding each pulse) were analyzed by the Holm-Sidak one-way repeated measures ANOVA and post hoc analyses of pair-wise comparisons were completed using paired t-tests. Data are reported as mean \pm SEM. Differences were considered significant when $\mathrm{P}<0.05$. 


\section{RESULTS}

\section{Experiment 1A: Effect of NKB microimplants in the RCh, POA, PVN, or ARC on LH release in}

follicular phase ewes. Most ewes in each group had correctly placed guide cannulae (5 of 6 in the RCh, 5 of 6 in the POA, 3 of 4 in the PVN, and 4 of 5 in the ARC). We consistently observed no significant effect of NKB microimplantation on LH secretion in any of these areas (Fig. 1). Low amplitude LH pulses were observed in all ewes and neither LH pulse amplitude nor frequency was altered by treatment in any area (data not shown).

\section{Experiment 1B: Effect of a senktide microinjection in the POA or PVN on LH release in follicular}

phase ewes. A single microinjection of senktide significantly stimulated LH secretion in the POA compared to saline $(2.15 \pm 0.38$ vs. $1.34 \pm 0.26 \mathrm{ng} / \mathrm{mL}$, respectively $)$, but not in the PVN $(1.87 \pm 0.40$ vs. $1.86 \pm 0.27$, respectively). On average, peak LH concentrations were observed 36 min following senktide injection and values returned to nadir within $1 \mathrm{~h}$.

\section{Experiment 2: Effect of NKB vs. senktide treatment in the RCh on LH secretion in anestrous ewes.}

Five of the seven ewes had correctly placed microimplant sites in the RCh (Fig. 2A). They were within 0.5-1.5 mm of the base of the brain and at the posterior end of the optic chiasm (Fig. 2A, left panel). Placement in two ewes was too posterior (Fig. 2A, right panel). The five ewes with appropriate placements responded to senktide microimplants with a significant and sustained increase in LH secretion (Fig. 2B), a response similar to that which we previously reported (18). LH concentrations peaked at 16.9 $\pm 3.4 \mathrm{ng} / \mathrm{mL} 3 \mathrm{~h}$ after microimplant insertion and remained significantly elevated for a total of $4.5 \mathrm{~h}$. The observed elevation in LH secretion was continuous, and pulses were undetectable during this period of elevated secretion. The two ewes with misplaced cannulae had a much lower LH peak $(\sim 3.5 \mathrm{ng} / \mathrm{mL})$, which was not significantly different than peak control values. In contrast to the effects of senktide, none of the ewes showed an increase in LH secretion during NKB treatment (Fig. 2B). Low frequency LH pulses were observed during treatment with either NKB or empty microimplants, and no changes in LH 
pulse frequency were observed $(1.4 \pm 0.3$ pulses and $1.4 \pm 0.4$ pulses in a $4 \mathrm{~h}$ period in controls and in NKB-treated groups, respectively).

\section{Experiment 3: Effect of senktide microimplants in the POA or ARC on LH secretion in follicular}

phase ewes. Five of six ewes had correct microimplant placements in the POA (Fig. 3A, light grey

circles; Note: The white circles in Fig. 3A and 3B depict placement of guide cannuluae in ewes from Exp.

1 that received NKB treatment and illustrate similar placement in the two experiments). Insertion of

empty microimplants had no obvious effects on LH secretion. All five ewes with correct cannulae

placement responded to senktide microimplants with a sustained increase in LH secretion, the average

peak being $22.4 \pm 9.1 \mathrm{ng} / \mathrm{mL}$ (Fig. 3C). The rise in LH was first significant $2 \mathrm{~h}$ after microimplant

insertion and remained significantly elevated throughout the sampling period. The observed elevation in

LH secretion was continuous, and pulses were undetectable during this period of elevated secretion. The

ewe with cannulae placement posterior to the POA had a lower maximum $\mathrm{LH}$ level of $\sim 2.8 \mathrm{ng} / \mathrm{mL}$, similar to that seen with control treatment.

Four of six ewes had correctly placed microimplant sites in the ARC (Fig. 3B, light grey circles); in each of the other 2 ewes, one guide cannula was placed within the third ventricle. All four ewes with correct cannulae placement responded to senktide microimplants with an increase in LH secretion as compared to empty implants (Fig. 3D). However, the average peak LH secretion $(5.8 \pm 2.5 \mathrm{ng} / \mathrm{mL})$ was significantly lower than that observed in the POA group. Senktide treatment did not alter LH pulse amplitude, but decreased LH pulse frequency compared to controls $(0.4 \pm 0.1$ pulse/h vs. $0.8 \pm 0.1$ pulse $/ \mathrm{h}$, respectively), and increased the mean nadir values $(4.53 \pm 1.53 \mathrm{ng} / \mathrm{mL}$ vs. $0.98 \pm 0.20 \mathrm{ng} / \mathrm{mL}$, respectively). Each of the two ewes with one of the guide cannulae in the third ventricle had much higher peak LH values, averaging $52.2 \mathrm{ng} / \mathrm{mL}$.

Experiment 4: Effect of SB222200 in the RCh or POA on the $E_{2}$-induced LH surge. Four of the five ewes in the RCh group had correct placement of guide cannulae (data not shown), while the end of the guide tubes rested within the optic chiasm of the fifth ewe. LH surges are shown for two representative 
ewes with guide cannulae targeting the RCh in Fig. 4A. LH surges occurred in all five ewes, regardless of treatment, with peak LH release after insertion of the four $\mathrm{E}_{2}$ implants occurring at $24.5 \pm 2.6 \mathrm{~h}$ in controls and $27.7 \pm 2.8 \mathrm{~h}$ in SB222200-treated ewes $(\mathrm{P}>0.05)$. All four ewes with correct placement of cannulae exhibited blunted LH surge amplitudes when treated with SB222200 in the RCh so that mean amplitude was significantly less compared to that during treatment with empty microimplants $(108.4 \pm 17.5 \mathrm{vs}$. $185.1 \pm 10.2 \mathrm{ng} / \mathrm{mL}$, respectively; Fig. 4B). In the ewe with missed cannulae placement, LH surge peak amplitude was higher during SB222200 treatment than during control treatment $(232.2 \mathrm{ng} / \mathrm{mL}$ vs. 132.2 $\mathrm{ng} / \mathrm{mL}$, respectively).

All six ewes in the POA group had accurate guide cannulae placement and all exhibited $\mathrm{E}_{2}$ induced LH surges regardless of treatment, with peak $\mathrm{LH}$ values post- $\mathrm{E}_{2}$ treatment occurring at $23.6 \pm 1.0$ $\mathrm{h}$ in controls and at $25.0 \pm 0.9 \mathrm{~h}$ in SB222200-treated ewes, which did not differ significantly. Average peak LH levels were not different between treatments (Fig. 4C). Amplitudes of LH surges during treatment with empty implants were noticeably higher in ewes of the RCh group compared to those in the POA group. This difference is likely due to the fact that the RCh work was carried out in the middle of the breeding season whereas the POA experiment was performed near the end of the breeding season. Previous work has shown that LH surge amplitude using this surge-inducing paradigm is greater earlier in the breeding season than later (41).

\section{DISCUSSION}

The presence of NK3R and kisspeptin in KNDy neurons has led to the hypothesis that NKB elicits LH release by autocrine or paracrine actions on ARC KNDy neurons to cause kisspeptin release which in turn stimulates GnRH release. However, NK3R expression is also relatively high in other areas of the hypothalamus (POA, PVN, and RCh). This raises the possibility that NKB may also act in these other areas to influence GnRH/LH release. We found that senktide stimulated surge-like LH secretion when administered within the ovine RCh or POA but produced a more modest increase in the ARC and had no effect in the PVN. These results point to both the POA and RCh as possible sites for NKB 
stimulation during the GnRH/LH surge, but only blockade of the NK3R in the RCh reduced LH surge amplitude. This confirms and extends previous data from our laboratory that demonstrated stimulatory effects of senktide in the RCh (18). In contrast, we did not find any significant effect of NKB on LH secretion when placed in the POA, RCh, ARC or PVN.

The increase in LH release following administration of senktide in the RCh and POA resembled surge-like LH secretion, suggesting that NKB may be involved in the GnRH/LH surge, a hypothesis that until now has not been directly tested. However, the sex-specific nature of the GnRH/LH surge and NKB gene and protein expression is consistent with the proposal that NKB may be involved in the GnRH/LH surge. Female sheep have relatively high numbers of NKB-immunoreactive cells or levels of NKB gene expression and the capability of exhibiting LH surges while males or androgenized females express significantly less NKB and fail to exhibit an $\mathrm{E}_{2}$-induced LH surge $(8,42)$.

Although a number of studies have demonstrated stimulatory effects of NK3R agonists on LH secretion, this is the first to show, using a receptor antagonist, that NK3R activation is essential for the full LH surge. This effect seemed specific to the RCh as SB222200 placed in the POA, or in the one RCh ewe with misplaced guide cannulae, did not alter the $\mathrm{E}_{2}$-induced LH surge. In contrast, senktide treatment in both areas stimulated surge-like LH secretion. While the lack of effect of SB222200 would appear to rule out a role for POA NK3R in the endogenous GnRH surge, it is important to note that neurons expressing NK3R in the POA are more widely scattered than NK3R-positive neurons in the RCh (29). This difference provides a possible alternative explanation for these data. Senktide, which is highly soluble in water, may have diffused far enough to reach sufficient receptors in both areas to stimulate surge-like LH release, while SB222200, which is relatively insoluble in water, may not have reached enough NK3R-positive cells in the POA to affect the LH surge, but did so when placed in the RCh.

The identity of neurons in the RCh that express NK3R is unknown, but they do not appear to be the A15 population of dopamine neurons (18) that are prominently involved in seasonal breeding $(43,44)$. Likewise, the pathway through which activation of RCh NK3R acts to stimulate LH secretion is yet to be identified, but may well involve kisspeptin neurons. The importance of kisspeptin in the LH surge has 
previously been demonstrated with intracerebroventricular administration of a Kiss1r antagonist suppressing the LH surge amplitude by $\sim 50 \%$ in ewes (32). Our data showing a similar degree of suppression (42\%) of the LH surge raise the possibility that the NK3R antagonist is blocking the same neural pathway as the Kiss1r antagonist in that study. Neither SB222200 treatment nor the Kiss1r antagonist (32) alters the timing of the surge, which may indicate that NKB and kisspeptin act only to ensure the full expression of the LH surge, but do not act to initiate the surge.

We cannot rule out the possibility that the incomplete blockage of the LH surge is a result of the SB222200 treatment not fully blocking all NK3R in the RCh. Moreover, NK3R in multiple areas (other than just RCh) may need to be blocked in order to completely prevent the LH surge because several hypothalamic areas appear to participate in the LH surge in ewes. For example, in addition to the RCh, the POA and MBH are involved because Fos expression in kisspeptin (45) and GnRH (46) neurons in both the POA and MBH is increased at the time of surge.

Unexpectedly, we found that NKB was ineffective in influencing LH secretion whereas senktide clearly increased in LH release. We would put forward two possible explanations for this discrepancy. The first is based on possible differences in the bioavailability of senktide and NKB. Senktide, but not $\mathrm{NKB}$, is highly soluble in aqueous solutions. Thus, it is possible that senktide diffused much further than NKB, giving it the opportunity to interact with more NK3R at higher concentrations. Senktide may also be metabolized more slowly than NKB because it is a synthetic peptide, further increasing its ability to interact with receptors for a longer period of time than NKB. The second possible explanation is based on the varying receptor selectivity of NKB and senktide. Senktide is highly selective for the NK3 isoform (47), while NKB can bind to all three subtypes (NK1R, NK2R, and NK3R), albeit having the highest binding affinity for NK3R. Interaction with other receptor subtypes could account for the ineffectiveness of NKB if either of the other receptor types is inhibitory to LH secretion in ewes. There is evidence that activation of NK2R by neuropeptide K (NPK) or activation of NK1R by substance P can inhibit LH secretion in female rats $(48,49)$, although stimulatory effects of these agonists have also been observed (50). It was also recently reported that ex vivo $\mathrm{NKB}$ stimulation of murine ARC kisspeptin neurons was 
blocked only by applying a cocktail of NK1R, NK2R, and NK3R antagonists, but not by the application of an NK3R antagonist alone (51). These findings suggest that NKB can activate multiple tachykinin receptor subtypes in KNDy neurons. It should be noted, however, that this explanation for the different effects of senktide and NKB requires the expression of these NKB receptor subtypes in the same areas in the ovine hypothalamus, but at this time there is no evidence regarding the distribution of NK1R or NK2R expression in sheep.

Although we cannot rule out the possibility that higher doses of senktide would be effective, the observation that senktide microinjection in the PVN does not alter LH concentration suggests that NK3R in this region may be involved in other effects of $\mathrm{NKB}$, such as regulation of vasopressin release (50). In contrast, the significant but small LH response to ARC senktide treatment indicates that ARC NK3R are likely not involved in LH surge regulation. Surprisingly here, senktide microimplants in the ARC decreased LH pulse frequency while it is previously reported that NKB microimplants in this area consistently increased LH pulse frequency in OVX ewes (37). The observed decrease in pulse frequency may reflect the increase in LH concentrations we noted between pulses, making pulse identification difficult. A similar effect of senktide has also been noted in OVX ewes (52). In any case, the relatively modest increase in mean LH concentrations (compared to senktide effects in the RCh and POA) may indicate a role for ARC NKB signaling in governing tonic LH secretion. This is consistent with previous data implicating KNDy neurons in the control of episodic GnRH secretion (33).

While these data indicate that NKB contributes to the LH surge in sheep, it is unlikely to play a similar role in rats because a Kiss1r antagonist completely blocked the surge in this species (53). In agreement with the lack of NKB involvement in the rodent surge, several lines of data indicate that the positive feedback action of $E_{2}$ in rodents is mediated by AVPV kisspeptin neurons (54-56). In contrast $E_{2}$ acts in the MBH of sheep to induce the LH surge (57), so it is not surprising that different neural systems are involved in these species. Since $\mathrm{E}_{2}$ also acts in the MBH to induce the LH surge in primates (58), we suggest that the role NK3R in sheep may be similar to that in non-human primates and humans. This possibility is consistent with the genetic data indicating that NKB/NK3R interaction is essential for 
reproduction in humans (2). In contrast, NK3R knockout mice remain fertile (59), albeit with some deficits in reproductive function (60). This indicates that NKB is not necessary for ovulatory cycles in mice, but does appear to be critical in sheep and humans.

In summary, we show herein that administration of the NK3R agonist senktide in either the POA or RCh stimulates surge-like LH secretion and that blockade of the NK3R in the RCh attenuates the amplitude of the LH surge. The mechanisms underlying the effectiveness of senktide, but ineffectiveness of NKB, in eliciting surge-like LH secretion are unclear, but may be explained in part by participation of other NKB receptor isoforms. While the area of the ARC in the sheep is believed to be where $\mathrm{E}_{2}$ acts to induce a GnRH/LH surge, the neural mechanisms involved are much less understood. Based on these data we hypothesize that activation of NK3R by NKB plays an important part in this pathway. 
Reference List

1. Rance NE, Young WS, III 1991 Hypertrophy and increased gene expression of neurons containing neurokinin-B and substance-P messenger ribonucleic acids in the hypothalami of postmenopausal women. Endocrinology 128:2239-2247

2. Topaloglu AK, Reimann F, Guclu M, Yalin AS, Kotan LD, Porter KM, Serin A, Mungan NO, Cook JR, Ozbek MN, Imamoglu S, Akalin NS, Yuksel B, O'Rahilly S, Semple RK 2009 TAC3 and TACR3 mutations in familial hypogonadotropic hypogonadism reveal a key role for Neurokinin B in the central control of reproduction. Nat Genet 41:354-358

3. Goodman RL, Karsch FJ 1980 Pulsatile secretion of luteinizing hormone: differential suppression by ovarian steroids. Endocrinology 107:1286-1290

4. Fox SR, Harlan RE, Shivers BD, Pfaff DW 1990 Chemical characterization of neuroendocrine targets for progesterone in the female rat brain and pituitary. Neuroendocrinology 51:276-283

5. Skinner DC, Caraty A, Allingham R 2001 Unmasking the progesterone receptor in the preoptic area and hypothalamus of the ewe: no colocalization with gonadotropin-releasing neurons.

Endocrinology 142:573-579

6. Lehman MN, Karsch FJ 1993 Do gonadotropin-releasing hormone, tyrosine hydroxylase-, and beta-endorphin-immunoreactive neurons contain estrogen receptors? A double-label immunocytochemical study in the Suffolk ewe. Endocrinology 133:887-895

7. Wintermantel TM, Campbell RE, Porteous R, Bock D, Grone HJ, Todman MG, Korach KS, Greiner E, Perez CA, Schutz G, Herbison AE 2006 Definition of estrogen receptor pathway critical for estrogen positive feedback to gonadotropin-releasing hormone neurons and fertility. Neuron 52:271-280

8. Goubillon ML, Forsdike RA, Robinson JE, Ciofi P, Caraty A, Herbison AE 2000 Identification of neurokinin B-expressing neurons as an highly estrogen-receptive, sexually dimorphic cell group in the ovine arcuate nucleus. Endocrinology 141:4218-4225

9. Eghlidi DH, Haley GE, Noriega NC, Kohama SG, Urbanski HF 2010 Influence of age and 17 beta-estradiol on kisspeptin, neurokinin B, and prodynorphin gene expression in the arcuatemedian eminence of female rhesus macaques. Endocrinology 151:3783-3794

10. Sandoval-Guzman T, Stalcup ST, Krajewski SJ, Voytko ML, Rance NE 2004 Effects of ovariectomy on the neuroendocrine axes regulating reproduction and energy balance in young cynomolgus macaques. J Neuroendocrinol 16:146-153

11. Nestor CC, Briscoe AM, Davis SM, Valent M, Goodman RL, Hileman SM 2012 Evidence of a role for kisspeptin and neurokinin B in puberty of female sheep. Endocrinology 153:2756-2765

12. Rance NE, Bruce TR 1994 Neurokinin B gene expression is increased in the arcuate nucleus of ovariectomized rats. Neuroendocrinology 60:337-345

13. Kauffman AS, Navarro VM, Kim J, Clifton DK, Steiner RA 2009 Sex differences in the regulation of Kiss1/NKB neurons in juvenile mice: implications for the timing of puberty. American Journal of Physiology-Endocrinology and Metabolism 297:E1212-E1221 
14. Navarro VM, Gottsch ML, Chavkin C, Okamura H, Clifton DK, Steiner RA 2009 Regulation of gonadotropin-releasing hormone secretion by kisspeptin/dynorphin/neurokinin B neurons in the arcuate nucleus of the mouse. J Neurosci 29:11859-11866

15. Abel TW, Voytko ML, Rance NE 1999 The effects of hormone replacement therapy on hypothalamic neuropeptide gene expression in a primate model of menopause. J Clin Endocrinol Metab 84:2111-2118

16. Dellovade TL, Merchenthaler I 2004 Estrogen regulation of neurokinin B gene expression in the mouse arcuate nucleus is mediated by estrogen receptor alpha. Endocrinology 145:736-742

17. Pillon D, Caraty A, Fabre-Nys C, Bruneau G 2003 Short-term effect of oestradiol on neurokinin B mRNA expression in the infundibular nucleus of ewes. J Neuroendocrinol 15:749-753

18. Billings HJ, Connors JM, Altman SN, Hileman SM, Holaskova I, Lehman MN, McManus CJ, Nestor CC, Jacobs BH, Goodman RL 2010 Neurokinin B acts via the neurokinin-3 receptor in the retrochiasmatic area to stimulate luteinizing hormone secretion in sheep. Endocrinology $151: 3836-3846$

19. Sakamoto K, Murata K, Wakabayashi Y, Yayou K, Ohkura S, Takeuchi Y, Mori Y, Okamura H 2012 Central administration of neurokinin B activates kisspeptin/NKB neurons in the arcuate nucleus and stimulates luteinizing hormone secretion in ewes during the non-breeding season. J Reprod Dev 58:700-706

20. Ramaswamy S, Seminara SB, Ali B, Ciofi P, Amin NA, Plant TM 2010 Neurokinin B stimulates GnRH release in the male monkey (Macaca mulatta) and is colocalized with kisspeptin in the arcuate nucleus. Endocrinology 151:4494-4503

21. Navarro VM, Castellano JM, McConkey SM, Pineda R, Ruiz-Pino F, Pinilla L, Clifton DK, Tena-Sempere M, Steiner RA 2011 Interactions between kisspeptin and neurokinin B in the control of GnRH secretion in the female rat. Am J Physiol Endocrinol Metab 300:E202-E210

22. Garcia-Galiano D, van Ingen SD, Leon S, Krajnc-Franken MA, Manfredi-Lozano M, Romero-Ruiz A, Navarro VM, Gaytan F, van Noort PI, Pinilla L, Blomenrohr M, TenaSempere M 2012 Kisspeptin signaling is indispensable for neurokinin B, but not glutamate, stimulation of gonadotropin secretion in mice. Endocrinology 153:316-328

23. Navarro VM, Gottsch ML, Wu M, Garcia-Galiano D, Hobbs SJ, Bosch MA, Pinilla L, Clifton DK, Dearth A, Ronnekleiv OK, Braun RE, Palmiter RD, Tena-Sempere M, Alreja M, Steiner RA 2011 Regulation of NKB pathways and their roles in the control of Kiss1 neurons in the arcuate nucleus of the male mouse. Endocrinology 152:4265-4275

24. Kinsey-Jones JS, Grachev P, Li XF, Lin YS, Milligan SR, Lightman SL, O'Byrne KT 2012 The inhibitory effects of neurokinin $\mathrm{B}$ on GnRH pulse generator frequency in the female rat. Endocrinology 153:307-315

25. Sandoval-Guzman T, Rance NE 2004 Central injection of senktide, an NK3 receptor agonist, or neuropeptide $\mathrm{Y}$ inhibits LH secretion and induces different patterns of Fos expression in the rat hypothalamus. Brain Res 1026:307-312 
26. Goodman RL, Lehman MN, Smith JT, Coolen LM, de Oliveira CV, Jafarzadehshirazi MR, Pereira A, Iqbal J, Caraty A, Ciofi P, Clarke IJ 2007 Kisspeptin neurons in the arcuate nucleus of the ewe express both dynorphin A and neurokinin B. Endocrinology 148:5752-5760

27. Messager S, Chatzidaki EE, Ma D, Hendrick AG, Zahn D, Dixon J, Thresher RR, Malinge I, Lomet D, Carlton MB, Colledge WH, Caraty A, Aparicio SA 2005 Kisspeptin directly stimulates gonadotropin-releasing hormone release via $\mathrm{G}$ protein-coupled receptor 54 . Proc Natl Acad Sci U S A 102:1761-1766

28. Burke MC, Letts PA, Krajewski SJ, Rance NE 2006 Coexpression of dynorphin and neurokinin B immunoreactivity in the rat hypothalamus: Morphologic evidence of interrelated function within the arcuate nucleus. J Comp Neurol 498:712-726

29. Amstalden M, Coolen LM, Hemmerle AM, Billings HJ, Connors JM, Goodman RL, Lehman MN 2010 Neurokinin 3 receptor immunoreactivity in the septal region, preoptic area and hypothalamus of the female sheep: colocalisation in neurokinin B cells of the arcuate nucleus but not in gonadotrophin-releasing hormone neurones. J Neuroendocrinol 22:1-12

30. Gottsch ML, Cunningham MJ, Smith JT, Popa SM, Acohido BV, Crowley WF, Seminara S, Clifton DK, Steiner RA 2004 A role for kisspeptins in the regulation of gonadotropin secretion in the mouse. Endocrinology 145:4073-4077

31. Irwig MS, Fraley GS, Smith JT, Acohido BV, Popa SM, Cunningham MJ, Gottsch ML, Clifton DK, Steiner RA 2004 Kisspeptin activation of gonadotropin releasing hormone neurons and regulation of KiSS-1 mRNA in the male rat. Neuroendocrinology 80:264-272

32. Smith JT, Li Q, Yap KS, Shahab M, Roseweir AK, Millar RP, Clarke IJ 2011 Kisspeptin is essential for the full preovulatory LH surge and stimulates GnRH release from the isolated ovine median eminence. Endocrinology 152:1001-1012

33. Lehman MN, Coolen LM, Goodman RL 2010 Minireview: Kisspeptin/Neurokinin B/Dynorphin (KNDy) Cells of the Arcuate Nucleus: A Central Node in the Control of Gonadotropin-Releasing Hormone Secretion. Endocrinology 151:3479-3489

34. Wakabayashi Y, Nakada T, Murata K, Ohkura S, Mogi K, Navarro VM, Clifton DK, Mori Y, Tsukamura H, Maeda K, Steiner RA, Okamura H 2010 Neurokinin B and dynorphin A in kisspeptin neurons of the arcuate nucleus participate in generation of periodic oscillation of neural activity driving pulsatile gonadotropin-releasing hormone secretion in the goat. J Neurosci 30:31243132

35. Anderson GM, Connors JM, Hardy SL, Valent M, Goodman RL 2001 Oestradiol microimplants in the ventromedial preoptic area inhibit secretion of luteinizing hormone via dopamine neurones in anoestrous ewes. J Neuroendocrinol 13:1051-1058

36. Foradori CD, Goodman RL, Adams VL, Valent M, Lehman MN 2005 Progesterone increases dynorphin a concentrations in cerebrospinal fluid and preprodynorphin messenger ribonucleic Acid levels in a subset of dynorphin neurons in the sheep. Endocrinology 146:1835-1842

37. Goodman RL, Hileman SM, Nestor CC, Porter KL, Connors JM, Hardy SL, Millar RP, Cernea M, Coolen LM, Lehman MN 2013 Kisspeptin, neurokinin B, and dynorphin act in the arcuate nucleus to control activity of the GnRH pulse generator in ewes. Endocrinology 
38. Skinner DC, Harris TG, Evans NP 2000 Duration and Amplitude of the Luteal Phase Progesterone Increment Times the Estradiol-Induced Luteinizing Hormone Surge in Ewes. Biology of Reproduction 63:1135-1142

39. Goodman RL, Coolen LM, Anderson GM, Hardy SL, Valent M, Connors JM, Fitzgerald ME, Lehman MN 2004 Evidence that dynorphin plays a major role in mediating progesterone negative feedback on gonadotropin-releasing hormone neurons in sheep. Endocrinology 145:2959-2967

40. Goodman RL, Maltby MJ, Millar RP, Hileman SM, Nestor CC, Whited B, Tseng AS, Coolen LM, Lehman MN 2012 Evidence that dopamine acts via kisspeptin to hold GnRH pulse frequency in check in anestrous ewes. Endocrinology 153:5918-5927

41. Goodman RL, Bittman EL, Foster DL, Karsch FJ 1981 The endocrine basis of the synergistic suppression of luteinizing hormone by estradiol and progesterone. Endocrinology 109:1414-1417

42. Foster DL, Padmanabhan V, Wood RI, Robinson JE 2002 Sexual differentiation of the neuroendocrine control of gonadotrophin secretion: concepts derived from sheep models. Reproduction Supplement 59:83-99

43. Lehman MN, Durham DM, Jansen HT, Adrian B, Goodman RL 1996 Dopaminergic A14/A15 neurons are activated during estradiol negative feedback in anestrous, but not breeding season, ewes. Endocrinology 137:4443-4450

44. Thiery JC, Gayrard V, Le CS, Viguie C, Martin GB, Chemineau P, Malpaux B 1995 Dopaminergic control of LH secretion by the A15 nucleus in anoestrous ewes. J Reprod Fertil Suppl 49:285-296

45. Merkley CM, Porter KL, Coolen LM, Hileman SM, Billings HJ, Drews S, Goodman RL, Lehman MN 2012 KNDy (kisspeptin/neurokinin B/dynorphin) neurons are activated during both pulsatile and surge secretion of LH in the ewe. Endocrinology 153:5406-5414

46. Moenter SM, Karsch FJ, Lehman MN 1993 Fos expression during the estradiol-induced gonadotropin-releasing hormone $(\mathrm{GnRH})$ surge of the ewe: induction in $\mathrm{GnRH}$ and other neurons. Endocrinology 133:896-903

47. Wormser U, Laufer R, Hart Y, Chorev M, Gilon C, Selinger Z 1986 Highly selective agonists for substance P receptor subtypes. EMBO J 5:2805-2808

48. Duval P, Lenoir V, Kerdelhue B 1998 The in vitro effect of substance P on the GnRH-induced LH release depends on the steroidal environment and is reverted by a NK1 receptor antagonist (RP 67580) in the cycling female rat. Neuropeptides 32:97-101

49. Sahu A, Kalra SP 1992 Effects of tachykinins on luteinizing hormone release in female rats: potent inhibitory action of neuropeptide K. Endocrinology 130:1571-1577

50. Hatae T, Kawano H, Karpitskiy V, Krause JE, Masuko S 2001 Arginine-vasopressin neurons in the rat hypothalamus produce neurokinin B and co-express the tachykinin NK-3 receptor and angiotensin II type 1 receptor. Arch Histol Cytol 64:37-44

51. de Croft S, Boehm U, Herbison AE 2013 Neurokinin B activates arcuate kisspeptin neurons through multiple tachykinin receptors in the male mouse. Endocrinology 
52. Goodman RL, Porter KL, Connors JM, Hileman SM 2013 Neurokinin B (NKB) and the NKB receptor agonist, senktide, act in the ovine arcuate nucleus to produce different patterns of LH release. Endocr Rev 34:

53. Pineda R, Garcia-Galiano D, Roseweir A, Romero M, Sanchez-Garrido MA, Ruiz-Pino F, Morgan K, Pinilla L, Millar RP, Tena-Sempere M 2010 Critical roles of kisspeptins in female puberty and preovulatory gonadotropin surges as revealed by a novel antagonist. Endocrinology 151:722-730

54. Koves K, Halasz B 1970 Location of the neural structures triggering ovulation in the rat. Neuroendocrinology 6:180-193

55. Petersen SL, Barraclough CA 1989 Suppression of spontaneous LH surges in estrogen-treated ovariectomized rats by microimplants of antiestrogens into the preoptic brain. Brain Res 484:279289

56. Wiegand SJ, Terasawa E, Bridson WE, Goy RW 1980 Effects of discrete lesions of preoptic and suprachiasmatic structures in the female rat. Alterations in the feedback regulation of gonadotropin secretion. Neuroendocrinology 31:147-157

57. Caraty A, Fabre-Nys C, Delaleu B, Locatelli A, Bruneau G, Karsch FJ, Herbison A 1998 Evidence that the mediobasal hypothalamus is the primary site of action of estradiol in inducing the preovulatory gonadotropin releasing hormone surge in the ewe. Endocrinology 139:1752-1760

58. Plant TM, Krey LC, Moossy J, McCormack JT, Hess DL, Knobil E 1978 The arcuate nucleus and the control of gonadotropin and prolactin secretion in the female rhesus monkey (Macaca mulatta). Endocrinology 102:52-62

59. Kung TT, Crawley Y, Jones H, Luo B, Gilchrest H, Greenfeder S, Anthes JC, Lira S, Wiekowski M, Cook DN, Hey JA, Egan RW, Chapman RW 2004 Tachykinin NK3-receptor deficiency does not inhibit pulmonary eosinophilia in allergic mice. Pharmacol Res 50:611-615

60. Yang JJ, Caligioni CS, Chan YM, Seminara SB 2012 Uncovering novel reproductive defects in neurokinin B receptor null mice: closing the gap between mice and men. Endocrinology 153:14981508 


\section{Figure 1}

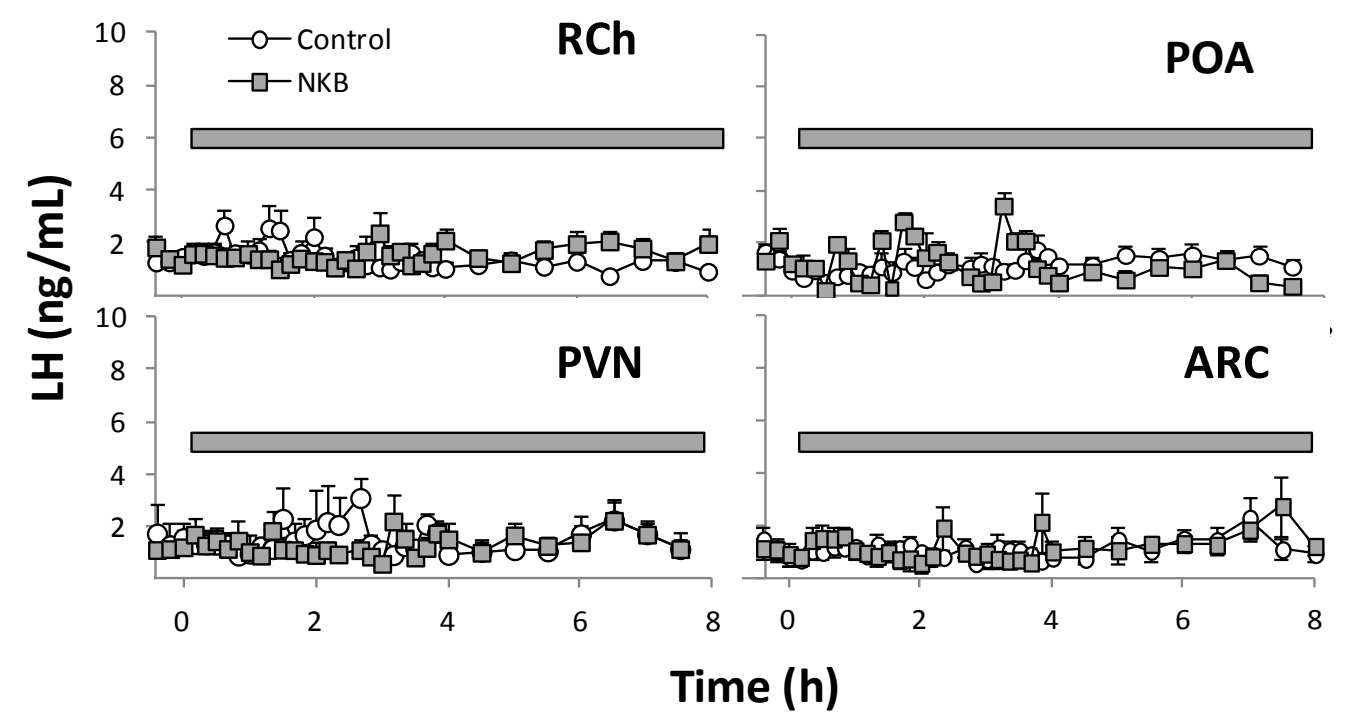

Figure 1. LH ( \pm SEM) concentrations during treatment with NKB-containing (shaded squares) or empty (open circles) microimplants in the $\mathrm{RCh}(\mathrm{n}=5), \operatorname{POA}(\mathrm{n}=5), \operatorname{PVN}(\mathrm{n}=3)$, and $\mathrm{ARC}(\mathrm{n}=4)$ of ewes during the early follicular phase. No significant differences in mean LH values or pulse frequency were observed. Grey bars indicate the time period of microimplant treatment. 


\section{Figure 2}

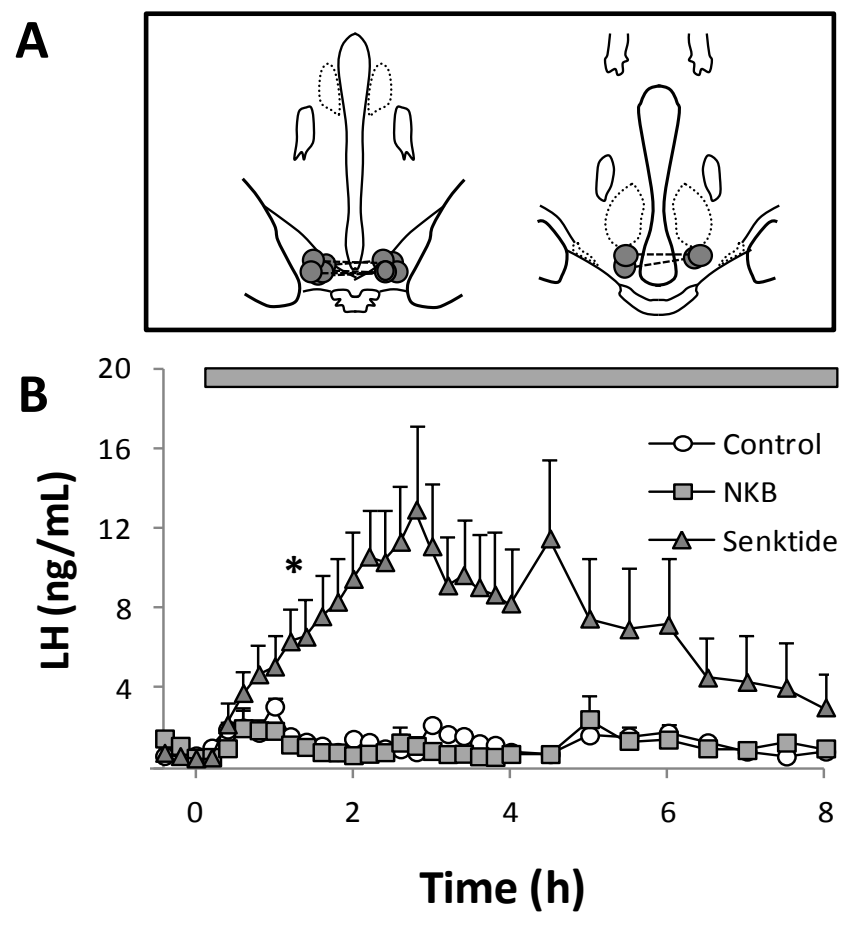

Figure 2. Top panel (A) depicts microimplant placement within the RCh in ewes used in Exp. 2. Bottom panel (B) depicts LH concentrations during treatment with NKB-containing (shaded squares), senktidecontaining (shaded triangles) or empty microimplants (open circles) in the RCh of intact anestrous ewes $(n=5)$. Values represent the mean $( \pm$ SEM) LH concentration from all ewes in each group, at each time point. The grey bar indicates the time period of microimplant treatment. The asterisk indicates the first point at which LH concentration in senktide-treated ewes was greater compared to controls. No difference in mean LH was observed between NKB-treated and control groups. 


\section{Figure 3}
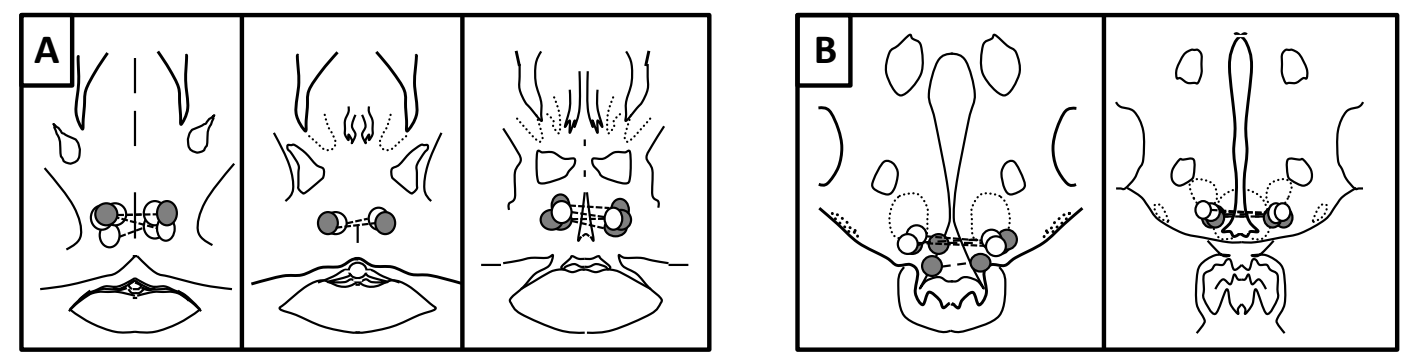

C

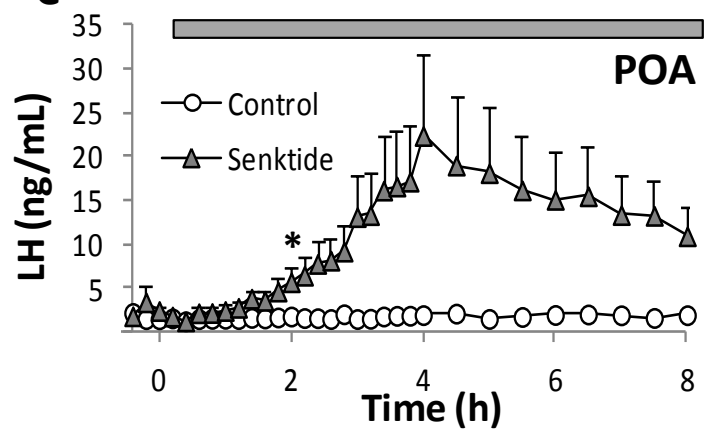

D

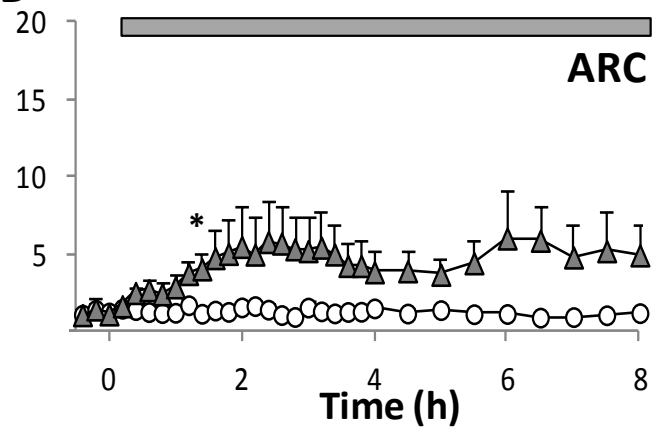

Figure 3. Top panel depicts microimplant placement within the POA (A) and ARC (B) in ewes used in Exp. 3 (grey circles) and ewes from Exp. 1 (treated with NKB; white circles). The bottom panel depicts the mean $( \pm$ SEM) LH concentrations during treatment with senktide-containing (shaded triangles) or empty (open circles) microimplants in the POA $(C ; n=5)$ or ARC $(D ; n=4)$ in, early follicular phase ewes. Grey bars indicate the time period of microimplant treatment. Asterisks indicate the first point at which the LH concentration in senktide-treated ewes was greater compared to controls. 


\section{Figure 4}
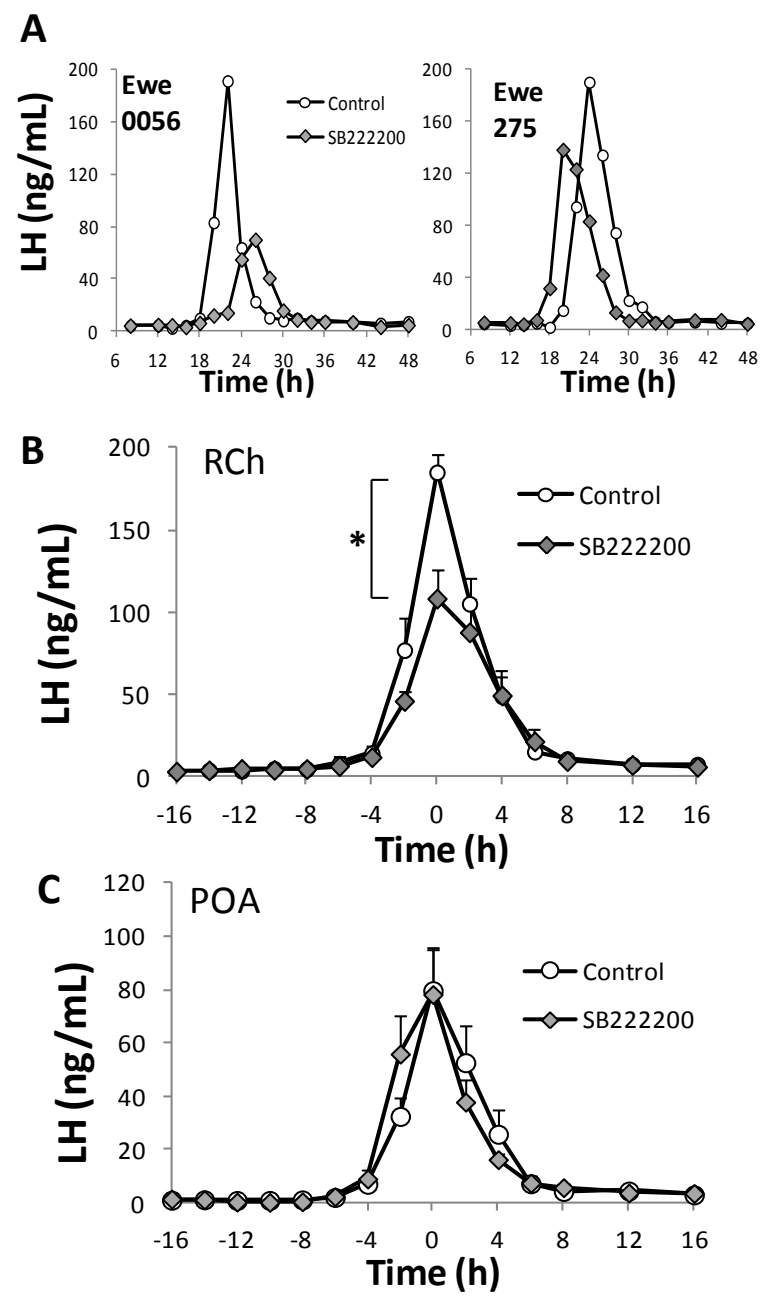

Figure 4. The top panel (A) depicts LH profiles from two representative ewes from the RCh group with or without SB222200 treatment during an $\mathrm{E}_{2}$-induced LH surge. The middle panel (B) shows the mean ( \pm SEM) LH concentrations from all ewes $(n=4)$ at each time point surrounding the LH surge with SB222200-containing (grey circles) or empty (open circles) microimplants in the RCh. The asterisk indicates that the LH surge amplitude in the presence of SB222200 was significantly lower $(\mathrm{P}<0.05)$ than the amplitude observed with empty microimplants. The bottom panel (C) shows the mean ( \pm SEM) LH concentration from all ewes $(n=6)$ treated with SB222200-containing (grey circles) or empty (open circles) microimplants in the POA during an $\mathrm{E}_{2}$-induced surge. No differences in surge amplitude were observed. Time to LH peak did not differ by treatment in either the RCh or the POA groups. 


\section{CHAPTER 4}

\section{SENKTIDE STIMULATES LH SECRETION VIA ARCUATE KISSPEPTIN NEURONS IN EWES}

Katrina L. Porter, Stanley M. Hileman, and Robert L. Goodman

Department of Physiology and Pharmacology, West Virginia University, Morgantown, West Virginia 26506

Running title: Senktide via kisspeptin activation 


\begin{abstract}
The NK3R agonist, senktide, is a potent stimulator of LH release in non-rodent species, including sheep. Specifically, in ewes, senktide placed within the retrochiasmatic area of the hypothalamus ( $\mathrm{RCh})$ or preoptic area (POA) elicited surge-like LH secretion and administration of an NK3R-antagonist within the RCh significantly reduced the amplitude of an $\mathrm{E}_{2}$-induced LH surge. Together, these findings suggest that NKB acts within these areas to regulate the preovulatory LH surge. However, the pathway through which NK3R activation in these areas stimulates GnRH/LH secretion remains unclear. Several studies suggest that NKB may act by eliciting kisspeptin release from KNDy (kisspeptin/neurokinin $\mathrm{B} /$ dynorphin) neurons, which have been shown to project directly to GnRH neurons. The aim of these studies was to determine if senktide-induced stimulation of LH release in ewes after placement within the RCh or POA involves kisspeptin release from KNDy neurons. Senktide microimplants in the RCh or POA increased the percentage of KNDy neurons that were active, as assessed by cFos colocalization, compared to empty implants, but did not alter activation of POA kisspeptin neurons.

Intracerebroventricular infusion of a Kiss1r antagonist blocked the RCh senktide-induced LH secretion in some ewes, but failed to do so in others. Thus, the effects of senktide may be kisspeptin-dependent, but further work will be needed to determine the relative importance of kisspeptin, and more specifically KNDy, neurons in this response.
\end{abstract}




\section{INTRODUCTION}

Neurokinin B (NKB) and kisspeptin have been the subject of intense focus recently, as they have both been identified as essential components of reproduction in humans (1-3). They clearly play an integral role in regulating GnRH and LH secretion in rodents (4-7), sheep (8-11), and primates $(12 ; 13)$. However, the manner in which these peptides, either separately or together, act to regulate GnRH release is unclear.

NKB and kisspeptin, along with dynorphin A, are coexpressed in a population of neurons located within the arcuate nucleus and thus have been termed KNDy neurons (14). At least in sheep and goats, KNDy neurons are thought to be a vital component of the LH pulse generator due to the following evidence: 1) KNDy neurons form an unusual reciprocal network, in which projections from KNDy neurons synapse on other KNDy neurons, perhaps enabling them to fire synchronously (15), 2) electrical recordings from the posterior ARC (where most kisspeptin neurons are located) in goats reveal pulsatile bursts of multi-unit activity from neurons in this area in association with LH pulses (16), and 3) KNDy neurons project to, and synapse on, $\mathrm{GnRH}$ neurons in the preoptic area (POA) as well as the mediobasal hypothalamus (MBH) (14). Furthermore, KNDy neurons express the primary NKB receptor (NK3R), but not the receptor for kisspeptin (Kiss1r). Virtually all GnRH neurons express Kiss1r, but not NK3R, laying the foundation for the hypothesis that NKB serves to stimulate kisspeptin release and thus the onset of a GnRH pulse, while dynorphin acts to terminate kisspeptin output and the GnRH pulse (14).

To date, essentially all studies on NKB have been focused on its putative role in GnRH pulse generation. However, we recently demonstrated in ewes that senktide treatment in the retrochiasmatic area $(\mathrm{RCh})$ or the POA, both areas which highly express NK3R (17), stimulates surge-like LH secretion, indicating that NKB-NK3R signaling may also play a role in the LH surge (see Chapter 3). In addition, we found that NK3R activation in the RCh is necessary for the full LH surge in ewes, as an antagonist to NK3R blunted LH surge amplitude by $42 \%$ (see Chapter 3). However, the neural pathway through which activation of NK3R outside of the arcuate nucleus (ARC) alters LH secretion is unclear. Since 
blockade of Kiss1r has previously been shown to cause a similar decrease in LH surge amplitude (11) and because KNDy neurons and POA kisspeptin neurons exhibit increased activation during the preovulatory LH surge (18), we tested the hypothesis that NK3R-positive neurons in the RCh or POA act via KNDy neurons and/or POA kisspeptin neurons to stimulate GnRH/LH secretion. In the first study, senktide was targeted to the RCh or POA and activation of KNDy or POA kisspeptin neurons assessed by cFos colocalization. The ability of senktide placed in the RCh to stimulate surge-like LH secretion in the presence of a Kiss1r antagonist was also assessed.

\section{METHODS}

\section{Animals}

Adult ewes of predominantly Suffolk breeding, housed indoors under a controlled photoperiod simulating natural outdoor day length were used for all experiments. Ewes were fed a pelleted alfalfa diet and provided free access to water and supplemental minerals. Experiments using anestrous ewes were performed from May to August, and experiments performed during the breeding season were done from October to February. Additionally, estrous cycles in ewes used for follicular phase experiments performed in the POA were synchronized as reported previously (8). Briefly, two intramuscular (im) injections of prostaglandin $\mathrm{F}_{2 \alpha}(5 \mathrm{mg} / \mathrm{mL}$, Luteolyse, Pharmacia \& Upjohn Co., NY, NY) were given $3 \mathrm{~h}$ apart, and this regimen was repeated seven days later. At this time two progesterone-containing controlled internal drug-releasing devices (CIDRs; Eazi-Breed, Pharmacia \& Upjohn, New York, NY) were inserted intravaginally to produce luteal phase levels of progesterone. Seven days later $\mathrm{PGF}_{2 \alpha}$ was again injected and CIDRs were removed. Experiments were begun $18 \mathrm{~h}$ later, during the early follicular phase. All procedures were approved by the West Virginia University Animal Care and Use Committee and conducted in accordance with NIH guidelines on the care and use of animals in research.

\section{Surgeries}

All surgeries were performed under sterile conditions using isofluorane anesthesia. In ewes in both Exps. 1 and 2, bilateral chronic 18-gauge guide cannulae were stereotaxically inserted into either the RCh 
or POA as previously described (19). In ewes in Exp. 1, a chronic 16-gauge cannula was also inserted into the lateral ventricle and secured in place, to be used for infusion of an antagonist. Ewes were treated with dexamethasone and penicillin pre- and post-operatively, and with daily analgesic (Banamine, Phoenix Pharmaceutical, St. Joseph, MO; $125 \mathrm{mg} / \mathrm{sheep}$ ) starting at the time of anesthesia induction and for 5 days after surgery.

\section{Experimental Approach}

\section{Experiment 1: Will a Kiss1r-antagonist block the senktide-induced increase in LH secretion?}

Part 1: To determine if the Kiss1r antagonist (p234-penetratin; EZ Biolab Inc., Carmel, IN) was able to inhibit LH pulse frequency, two ewes underwent OVX and neurosurgery for insertion of a cannula into the lateral ventricle. Following a recovery period of one week saline $(120 \mu \mathrm{L} / \mathrm{hr})$ or the Kiss $1 \mathrm{r}$ antagonist (300 ug/hr) was infused ICV for $2 \mathrm{~h}$ and frequent blood samples collected via jugular catheter (every $12 \mathrm{~min}$ ) for $7 \mathrm{~h}$, starting $2 \mathrm{~h}$ before the infusion. One week later, the experiment was repeated with a crossover of ICV treatment, so that each ewe received each treatment once. The vial of Kiss1r antagonist (p235-pentetratin) was reconstituted in sterile physiological saline upon arrival and small aliquots were frozen and stored $\left(-20^{\circ} \mathrm{F}\right)$ until the day of the experiment.

Part 2: To determine whether the senktide-induced increase in LH secretion is kisspeptindependent, a Kiss1r-antagonist was infused icv during RCh senktide treatment. Intact anestrous ewes ( $\mathrm{n}=$ 8) with bilateral guide cannulae aimed at the RCh and a lateral ventricle cannula were used. The Kiss1r antagonist $(300 \mu \mathrm{g} / \mathrm{h})$ or saline $(120 \mu \mathrm{L} / \mathrm{h})$ was infused into the lateral ventricle for one hour, at which time senktide-containing microimplants were inserted in the guide cannulae and left in place for the duration of the experiment. Infusion of p234-penetratin was continued for four more hours. Frequent blood samples (every 12 minutes) were collected via jugular catheters during the entire infusion period $(5 \mathrm{~h})$.

Microimplants were removed at the conclusion of blood sampling and, one week later, the experiment was repeated in a crossover design so that each ewe received the antagonist infusion once and saline infusion once. 
Part 3: To determine if the Kiss1r antagonist retained its efficacy following prolonged storage in the freezer, the experiment described in Part 1 was repeated in two new OVX ewes, with the difference being that blood samples were collected $2 \mathrm{~h}$ prior to infusion, $2 \mathrm{~h}$ during infusion, and $2 \mathrm{~h}$ post-infusion.

\section{Experiment 2: Does senktide in the RCh or POA activate ARC kisspeptin neurons?}

We previously demonstrated that the NK3R agonist senktide (obtained from Tocris Bioscience, Ellisville, MO) given in the RCh of intact anestrous ewes or POA of ewes during the early follicular phase stimulated surge-like LH secretion (see Chapter 3). Therefore, we used tissue sections from ewes in those previous studies and assessed activation of kisspeptin neurons, using cFos as an index of activation. Dual immunocytochemistry for kisspeptin and cFos (see below) was completed in tissues containing the ARC or POA (three sections/area/ewe) in order to examine both kisspeptin populations. The tissues were from ewes which received bilateral microimplants (constructed from 22-gauge stainless steel tubing and cut to extend $1.5 \mathrm{~mm}$ beyond the tip of the guide cannulae) that were empty or contained senktide in either the $\mathrm{RCh}$ ( $\mathrm{n}=5$ and $\mathrm{n}=7$, respectively) or POA ( $\mathrm{n}=5$ and $\mathrm{n}=6$, respectively); ewes were killed and tissue collected (see below) 3 hours after insertion of microimplants.

\section{Tissue Collection}

Ewes were euthanized via an overdose of sodium pentobarbital (8-12 $\mathrm{ml}$ of Euthasol; $390 \mathrm{mg}$ pentobarbital sodium/mL; Webster Veterinary, Devens MA). Two iv injections of heparin $(25,000 \mathrm{U})$ were given 10 minutes prior to, and immediately before, pentobarbital. The head was quickly removed and perfused via the carotid arteries with 6 liters of $4 \%$ paraformaldehyde in $0.1 \mathrm{M}$ phosphate buffer containing $0.1 \% \mathrm{NaNO}_{3}$. After perfusion, a block of tissue containing the POA and hypothalamus was dissected from the brain and stored in paraformaldehyde overnight at $4 \mathrm{C}$. The tissue was then infiltrated with $30 \%$ sucrose, and coronal sections (50 $\mu \mathrm{m}$ thick) were cut on a freezing microtome and stored at -20 $\mathrm{C}$ in cryoprotectant. A series of every fifth section was mounted on slides and stained with cresyl violet to evaluate cannulae placement. 


\section{Immunocytochemistry}

Dual immunocytochemistry for kisspeptin and cFos was carried out on free-floating sections at room temperature as previously described (18). Fos-ir nuclei were detected using an overnight incubation with a rabbit polyclonal antibody against c-Fos (1:2500; sc-253, Santa Cruz Biotechnology, Inc., Santa Cruz, CA), followed by incubation with biotinylated goat anti-rabbit $\operatorname{IgG}(1: 500$; Jackson ImmunoResearch Laboratories, Inc.) for $1 \mathrm{~h}$ and avidin-biotin-horseradish peroxidase complex (ABC-elite; 1:500; Vector Laboratories, Burlingame, CA) for $1 \mathrm{~h}$. Labeling was visualized using nickel-enhanced diaminobenzidine (DAB; Sigma) as the chromagen, which produces a black/purple reaction product that is limited to the nucleus. Next, the detection of kisspeptin was completed using a polyclonal rabbit antikisspeptin antibody (overnight at 1:50,000; no. 564, gift from A. Caraty, Universite Tours, Nouzilly, France), which has been previously validated for use in sheep $(18 ; 20)$. Sections were then incubated with biotinylated goat antirabbit IgG and followed by $\mathrm{ABC}$-elite as described above. Kisspeptin was visualized using DAB as the chromagen, which produces a brown reaction product within the cytoplasm. Sections were mounted on Superfrost slides, air-dried, dehydrated, and cover-slipped using Depex (DPX; Electron Microscopy Sciences, Hatfield, PA).

For each tissue section, the numbers of single kisspeptin and dual-labled kisspeptin/Fos cells were counted under bright-field illumination in the same manner as previously described (18). A cell was considered dual labeled when a black Fos-positive nucleus was observed to be surrounded by brown kisspeptin-positive cytoplasm in the same plane of focus. Percentage of dual labeling was calculated as the total number of dual-labeled cells divided by the total number of kisspeptin-positive cells.

\section{Assays}

LH was measured in duplicate using 100-200 $\mu$ of plasma in an RIA which has previously been validated in sheep (21), and expressed in terms of NIH-LH-S12. The minimal detectable concentration of LH in these assays averaged $0.10 \mathrm{ng} /$ tube; intra- and interassay coefficients of variation were 11.8 and $9.1 \%$, respectively. To confirm stage of the estrous cycle in ovary intact ewes, circulating progesterone 
was measured in duplicate aliquots of $150 \mu$ plasma using a commercially available solid-phase RIA kit (Coat-A-Count Kit, Diagnostics Products Corporation, Los Angeles, CA), which has been validated for use in sheep (22). Progesterone concentrations were $<0.3 \mathrm{ng} / \mathrm{ml}$ in all follicular phase ewes.

\section{Statistical Analysis}

In experiment 1 , all twelve ewes in the RCh group and 10 of 11 ewes in the POA group had proper placement of guide cannulae. In experiment 2, seven of eight ewes had proper placement of guide cannulae. Only ewes with proper guide cannulae placement were considered in the statistical analyses.

The mean number of single-labeled kisspeptin and dual-labeled kisspeptin/Fos cells in each area (POA and ARC) were counted for each animal, and the percentage of kisspeptin cells containing Fos was calculated. The mean and SEM were calculated for each group and $t$ tests were used to compare treatment groups. In experiment 2, statistically significant differences in mean LH concentrations among treatments were analyzed using a Kruskal-Wallis one-way ANOVA on ranks. Values of $\mathrm{P}<0.05$ were considered statistically significant.

\section{RESULTS}

\section{Experiment 1: Will a Kiss1 r-antagonist block the senktide-induced increase in LH secretion?}

Part 1: LH pulse frequency was inhibited during Kiss1r antagonist infusion in each ewe (Fig. 1). Frequency returned to baseline following conclusion of the infusion in both ewes.

Part 2: Mean LH concentrations prior to senktide treatment were similar between the saline- and Kiss1r antagonist-infused groups ( $2.3 \pm 0.4$ vs. $2.5 \pm 0.3 \mathrm{ng} / \mathrm{mL}$, respectively). LH concentrations significantly increased $(\mathrm{P}<0.05)$ following senktide treatment compared to pre-treatment concentrations $(\mathrm{P}<0.05)$ in the saline-infused group, but not the antagonist-infused group. However, there was not a significant difference in mean LH concentrations between the saline- and antagonist-infused groups during senktide treatment $(5.8 \pm 1.0$ vs. $8.0 \pm 3.4 \mathrm{ng} / \mathrm{mL}$, respectively; $\mathrm{P}>0.05)$. The reason for the lack of differences in the mean LH concentrations between groups is apparent when profiles from individual 
ewes are examined. Two ewes exhibited a large surge-like increase in LH secretion following senktide during icv saline infusion, but the LH response to senktide during icv infusion of the antagonist was suppressed (Fig. 2B). Conversely, two other ewes exhibited a large LH response to senktide only during infusion of the Kiss1r antagonist, but not during saline infusion (Fig. 2C). The final three ewes failed to respond to senktide treatment in the presence of icv infusion of Kiss1r antagonist or saline (Fig. 2A).

Part 3: LH pulse frequency was the same as baseline frequency during infusion of the Kiss 1r antagonist in one ewe (Fig. 3A) but was lower during infusion of the antagonist in the other ewe (Fig. 3B).

\section{Experiment 2: Does senktide in the RCh or POA activate ARC kisspeptin neurons?}

In the RCh group, average LH concentrations peaked at $16.9 \pm 3.4 \mathrm{ng} / \mathrm{mL}$ (Chapter 3, Exp. 2). In these ewes, the number of cells expressing kisspeptin was not significantly altered by treatment in either the ARC or the POA (data not shown). However, fewer kisspeptin neurons were observed within the POA compared to the ARC, consistent with what has previously been reported $(11 ; 18)$. Senktide treatment in the RCh significantly increased the percent colocalization of ARC kisspeptin/Fos compared to empty implants $(62.6 \pm 5.3 \%$ vs. $9.7 \pm 2.9 \%$; ; Fig. 4A). LH concentration was significantly higher in the senktide treated group compared to the control group at the time of perfusion (Fig. 4C). Senktide treatment in the RCh did not alter POA kisspeptin expression of Fos.

Following senktide treatment in the POA, average peak LH concentration was $22.4 \pm 9.1 \mathrm{ng} / \mathrm{mL}$ (Chapter 3, Exp. 3). No differences in the number of cells expressing kisspeptin were observed between treatment groups (data not shown). The percentage of ARC kisspeptin cells expressing Fos was significantly higher in the senktide-treated ewes compared to those receiving empty implants $(40.6 \pm$ $6.9 \%$ vs. $19.1 \pm 5.9 \%$; $<0.05$; Fig. 4B). LH concentration was significantly higher in the senktide treated group compared to the control group at the time of perfusion (Fig. 4D). Senktide in the POA did not significantly alter the percentage of POA kisspeptin neurons expressing Fos. 


\section{DISCUSSION}

To assess whether senktide acts in the RCh to stimulate LH secretion via kisspeptin, we attempted to block Kiss1r while treating with senktide in the RCh to see if senktide would still elicit LH secretion. Unfortunately we observed inconsistent results in this experiment. Consistent with the hypothesis that NK3R activation in the RCh acts through kisspeptin to cause LH secretion, we observed that the Kiss1r antagonist appeared to block the senktide-induced increase in LH secretion in two ewes. However, in two other ewes, we observed a response to senktide only during the Kiss1r antagonist infusion and not during saline infusion. In the three remaining ewes, senktide did not alter LH secretion during either the Kiss1r antagonist or saline infusion periods.

One possible reason for the discrepancy in these results is that the antagonist may have lost its efficacy prior to the final blood collection. Although the same lot and shipment of p234-pen was used for all experiments, and the antagonist was tested and confirmed to inhibit LH pulse frequency in OVX ewes (Figure 2) prior to use in this experiment, we suspect that the increased length of time stored in the freezer until the final experimental day may have led to decreased potency of the drug. We have previously observed a decrease in potency of other Kiss1r antagonists in our laboratory following prolonged storage, albeit on that occasion the length of time in storage was more prolonged. Therefore we tested the remainder of that lot of antagonist in two new OVX ewes and found that some of the efficacy had been lost (Figure 4). However, at least one of the ewes who received the Kiss1r antagonist during the second part of the crossover experiment exhibited a blunted response to senktide during the antagonist infusion, indicating that, at least in this animal, the antagonist retained its potency. We have further analyzed the data for effect of treatment order on efficacy of senktide treatment as well as placement of guide cannulae within the $\mathrm{RCh}$, but none of these parameters can explain the inconsistency in our results. One important aspect to also point out is that only 2 of 8 ewes exhibited a surge-like LH response to senktide during saline infusion. In previous experiments from our laboratory, senktide typically produces a very consistent LH response when placed in the RCh. Thus we conclude that there was likely an additional confounding factor or factors which contributed to the inconsistency in the results from this experiment. 
Two possible causes for the lack of effect of senktide in this experiment are: 1) the stress of saline infusion into the lateral ventricle may have inhibited LH secretion or 2) this experiment was done late in the anestrus season so that the seasonal decrease in NK3R expression in the RCh may have already begun (8). Therefore, while we believe that this experiment was well-designed, further experiments will be needed to obtain conclusive results. It is expected that such experiments will be completed during the next anestrus season.

Using Fos as an index of neuronal activation, we found that senktide treatment in either the RCh or the POA increases activation of KNDy neurons in conjunction with an increase in LH secretion, indicating that NK3R activation in the RCh or POA likely stimulates GnRH/LH secretion via ARC kisspeptin neurons. Kisspeptin has been suggested to mediate the effects of NKB across various species since NK3R are expressed in KNDy neurons in rats (23), mice (24), and sheep (17). One group found NK3R coexpressed by $16 \%$ of GnRH neurons in rats (23), however, no evidence for NK3R expression in GnRH neurons has been found in ewes (17). Additionally, blocking kisspeptin signaling has been shown to abolish the senktide-induced stimulation of LH secretion in monkeys (25), and a similar result is observed in GPR54 knockout mice, which failed to respond to senktide (26). All of these aforementioned workers proposed that senktide acts directly on KNDy neurons. In contrast, our data indicates that senktide can act in the RCh or POA to stimulate KNDy neurons indirectly. Our Fos data confirms that senktide acts at least in part via ARC kisspeptin neurons.

Although senktide treatment in the POA increased activation of KNDy neurons in conjunction with increased LH secretion, the increase from baseline kisspeptin/Fos colocalization was lower than that seen in KNDy neurons following RCh senktide treatment (5.5-fold increase compared to a 14-fold increase, respectively). This difference in activation fits with the difference in magnitude of the LH increase following senktide in the RCh compared to the POA in previous work. Senktide microimplants in the RCh in follicular phase ewes stimulated surge-like LH secretion with a peak of approximately 30 $\mathrm{ng} / \mathrm{mL}$ (8), while the average peak value we observed in our POA experimental group was $22 \mathrm{ng} / \mathrm{mL}$ (Chapter 3). The apparent larger response in the RCh may be due to the fact that the NK3R are expressed 
in a smaller area in the RCh compared to the pattern of expression in the POA, where NK3R are more widely scattered (17). In agreement with this, we have previously shown that an NK3R antagonist (SB222200) given in the POA does not alter an $\mathrm{E}_{2}$-induced LH surge (see Chapter 3), likely due to the low solubility of SB222200, making it difficult for the antagonist to reach the scattered NK3R-containing cells. However, senktide, which is highly soluble in aqueous solutions, is able to diffuse more fully and, therefore, it can interact with sufficient NK3R to stimulate the surge-like LH secretion, albeit to different degrees in different areas. While the identity of the NK3R-expressing neurons in POA is unknown, the lack of activation of POA kisspeptin neurons following POA senktide treatment indicates that the NK3Rpositive neurons are probably not kisspeptin neurons.

With senktide treatment in either the RCh or POA, there was no change observed in Fos expression in the POA kisspeptin neurons, which suggests that NK3R activation in these areas does not act via POA kisspeptin neurons. In contrast, during a typical preovulatory surge in ewes there is an increase in activation of both ARC and POA kisspeptin neurons (18). Therefore, lack of POA kisspeptin activation following senktide treatment suggests that either senktide is not inducing an LH surge or that senktide is only inducing a partial surge. The latter idea is supported by the fact that peak LH concentrations following senktide are approximately $22-32 \mathrm{ng} / \mathrm{mL}$, which is much lower than typical LH concentrations during an endogenous $\mathrm{LH}$ surge $(\sim 100 \mathrm{ng} / \mathrm{mL})$, as well as by our finding that the NK3R antagonist (SB222200) decreased the surge amplitude by only 40\% (Chapter 3). The pathway through which POA kisspeptin neurons are activated during the preovulatory surge is unknown. Since POA kisspeptin neurons do not express Kiss1r (11), it is unlikely that KNDy neurons are involved in their activation, which fits with the data herein.

Another piece of this puzzle which needs to be completed is to determine how NK3R-positive neurons in the RCh or POA interact with ARC kisspeptin neurons. Together with our collaborators, Dr. Michael Lehman and Dr. Lique Coolen, we are in the process of assessing projections from the RCh to the ARC via injection of an anterograde tract tracing agent into the RCh. Based on preliminary data (27), there appears to be direct projections from the RCh to KNDy neurons in the ARC, a finding which fits 
nicely with the increased activation of KNDy neurons presented herein. The identity of the RCh neurons that project to KNDy neurons and whether these neurons are the same population that express NK3R remains unknown. However, they are not the much studied A15 dopamine neurons (8) which are localized to the RCh of ewes and which play an important role in seasonal breeding $(28 ; 29)$. Further studies are needed to better characterize this pathway. Possible anatomical pathways connecting neurons in the POA with KNDy neurons have not yet been examined, although we plan to do this in future experiments.

In summary, our data herein show that activation of NK3R by senktide in either the RCh or POA results in stimulation of KNDy neurons and the concomitant surge-like LH secretion. However, this response does not seem to involve POA kisspeptin neurons. Confirmation that senktide acts only via kisspeptin neurons will need further experimentation since our attempt to block the effects of senktide in the RCh on LH release with a Kiss1r antagonist yielded mixed results. Hopefully, additional work will allow us to determine if NK3R activation in RCh elicits the robust increase in LH secretion exclusively via kisspeptin, or if other pathways are involved. 


\section{Reference List}

1. de Roux N, Genin E, Carel JC, Matsuda F, Chaussain JL, Milgrom E 2003 Hypogonadotropic hypogonadism due to loss of function of the KiSS1-derived peptide receptor GPR54. Proc Natl Acad Sci U S A 100:10972-10976

2. Seminara SB, Messager S, Chatzidaki EE, Thresher RR, Acierno JS, Jr., Shagoury JK, BoAbbas Y, Kuohung W, Schwinof KM, Hendrick AG, Zahn D, Dixon J, Kaiser UB, Slaugenhaupt SA, Gusella JF, O'Rahilly S, Carlton MB, Crowley WF, Jr., Aparicio SA, Colledge WH 2003 The GPR54 gene as a regulator of puberty. N Engl J Med 349:1614-1627

3. Topaloglu AK, Reimann F, Guclu M, Yalin AS, Kotan LD, Porter KM, Serin A, Mungan NO, Cook JR, Ozbek MN, Imamoglu S, Akalin NS, Yuksel B, O'Rahilly S, Semple RK 2009 TAC3 and TACR3 mutations in familial hypogonadotropic hypogonadism reveal a key role for Neurokinin B in the central control of reproduction. Nat Genet 41:354-358

4. Gottsch ML, Cunningham MJ, Smith JT, Popa SM, Acohido BV, Crowley WF, Seminara S, Clifton DK, Steiner RA 2004 A role for kisspeptins in the regulation of gonadotropin secretion in the mouse. Endocrinology 145:4073-4077

5. Matsui H, Takatsu Y, Kumano S, Matsumoto H, Ohtaki T 2004 Peripheral administration of metastin induces marked gonadotropin release and ovulation in the rat. Biochem Biophys Res Commun 320:383-388

6. Navarro VM, Castellano JM, McConkey SM, Pineda R, Ruiz-Pino F, Pinilla L, Clifton DK, Tena-Sempere M, Steiner RA 2011 Interactions between kisspeptin and neurokinin B in the control of GnRH secretion in the female rat. Am J Physiol Endocrinol Metab 300:E202-E210

7. Thompson EL, Patterson M, Murphy KG, Smith KL, Dhillo WS, Todd JF, Ghatei MA, Bloom SR 2004 Central and peripheral administration of kisspeptin-10 stimulates the hypothalamic-pituitary-gonadal axis. J Neuroendocrinol 16:850-858

8. Billings HJ, Connors JM, Altman SN, Hileman SM, Holaskova I, Lehman MN, McManus CJ, Nestor CC, Jacobs BH, Goodman RL 2010 Neurokinin B acts via the neurokinin-3 receptor in the retrochiasmatic area to stimulate luteinizing hormone secretion in sheep. Endocrinology $151: 3836-3846$

9. Messager S, Chatzidaki EE, Ma D, Hendrick AG, Zahn D, Dixon J, Thresher RR, Malinge I, Lomet D, Carlton MB, Colledge WH, Caraty A, Aparicio SA 2005 Kisspeptin directly stimulates gonadotropin-releasing hormone release via $\mathrm{G}$ protein-coupled receptor 54 . Proc Natl Acad Sci U S A 102:1761-1766

10. Nestor CC, Briscoe AM, Davis SM, Valent M, Goodman RL, Hileman SM 2012 Evidence of a role for kisspeptin and neurokinin B in puberty of female sheep. Endocrinology 153:2756-2765

11. Smith JT, Li Q, Yap KS, Shahab M, Roseweir AK, Millar RP, Clarke IJ 2011 Kisspeptin is essential for the full preovulatory LH surge and stimulates GnRH release from the isolated ovine median eminence. Endocrinology 152:1001-1012 
12. Ramaswamy S, Seminara SB, Ali B, Ciofi P, Amin NA, Plant TM 2010 Neurokinin B stimulates GnRH release in the male monkey (Macaca mulatta) and is colocalized with kisspeptin in the arcuate nucleus. Endocrinology 151:4494-4503

13. Shahab M, Mastronardi C, Seminara SB, Crowley WF, Ojeda SR, Plant TM 2005 Increased hypothalamic GPR54 signaling: a potential mechanism for initiation of puberty in primates. Proc Natl Acad Sci USA 102:2129-2134

14. Lehman MN, Coolen LM, Goodman RL 2010 Minireview: Kisspeptin/Neurokinin B/Dynorphin (KNDy) Cells of the Arcuate Nucleus: A Central Node in the Control of Gonadotropin-Releasing Hormone Secretion. Endocrinology 151:3479-3489

15. Foradori CD, Amstalden M, Goodman RL, Lehman MN 2006 Colocalisation of dynorphin a and neurokinin B immunoreactivity in the arcuate nucleus and median eminence of the sheep. Journal of Neuroendocrinology 18:534-541

16. Ohkura S, Takase K, Matsuyama S, Mogi K, Ichimaru T, Wakabayashi Y, Uenoyama Y, Mori Y, Steiner RA, Tsukamura H, Maeda KI, Okamura H 2009 Gonadotrophin-releasing hormone pulse generator activity in the hypothalamus of the goat. J Neuroendocrinol 21:813-821

17. Amstalden M, Coolen LM, Hemmerle AM, Billings HJ, Connors JM, Goodman RL, Lehman MN 2010 Neurokinin 3 receptor immunoreactivity in the septal region, preoptic area and hypothalamus of the female sheep: colocalisation in neurokinin B cells of the arcuate nucleus but not in gonadotrophin-releasing hormone neurones. J Neuroendocrinol 22:1-12

18. Merkley CM, Porter KL, Coolen LM, Hileman SM, Billings HJ, Drews S, Goodman RL, Lehman MN 2012 KNDy (kisspeptin/neurokinin B/dynorphin) neurons are activated during both pulsatile and surge secretion of LH in the ewe. Endocrinology 153:5406-5414

19. Goodman RL, Coolen LM, Anderson GM, Hardy SL, Valent M, Connors JM, Fitzgerald ME, Lehman MN 2004 Evidence that dynorphin plays a major role in mediating progesterone negative feedback on gonadotropin-releasing hormone neurons in sheep. Endocrinology 145:2959-2967

20. Goodman RL, Lehman MN, Smith JT, Coolen LM, de Oliveira CV, Jafarzadehshirazi MR, Pereira A, Iqbal J, Caraty A, Ciofi P, Clarke IJ 2007 Kisspeptin neurons in the arcuate nucleus of the ewe express both dynorphin A and neurokinin B. Endocrinology 148:5752-5760

21. Whisnant SC, Havern RL, Goodman RL 1991 Endogenous opioid suppression of luteinizing hormone pulse frequency and amplitude in the ewe: hypothalamic sites of action.

Neuroendocrinology 54:587-593

22. Anderson GM, Connors JM, Hardy SL, Valent M, Goodman RL 2001 Oestradiol microimplants in the ventromedial preoptic area inhibit secretion of luteinizing hormone via dopamine neurones in anoestrous ewes. J Neuroendocrinol 13:1051-1058

23. Krajewski SJ, Anderson MJ, Iles-Shih L, Chen KJ, Urbanski HF, Rance NE 2005 Morphologic evidence that neurokinin B modulates gonadotropin-releasing hormone secretion via neurokinin 3 receptors in the rat median eminence. J Comp Neurol 489:372-386 
24. Navarro VM, Gottsch ML, Wu M, Garcia-Galiano D, Hobbs SJ, Bosch MA, Pinilla L, Clifton DK, Dearth A, Ronnekleiv OK, Braun RE, Palmiter RD, Tena-Sempere M, Alreja M, Steiner RA 2011 Regulation of NKB pathways and their roles in the control of Kiss1 neurons in the arcuate nucleus of the male mouse. Endocrinology 152:4265-4275

25. Ramaswamy S, Seminara SB, Plant TM 2011 Evidence from the agonadal juvenile male rhesus monkey (Macaca mulatta) for the view that the action of neurokinin B to trigger gonadotropinreleasing hormone release is upstream from the kisspeptin receptor. Neuroendocrinology 94:237245

26. Garcia-Galiano D, van Ingen SD, Leon S, Krajnc-Franken MA, Manfredi-Lozano M, Romero-Ruiz A, Navarro VM, Gaytan F, van Noort PI, Pinilla L, Blomenrohr M, TenaSempere M 2012 Kisspeptin signaling is indispensable for neurokinin B, but not glutamate, stimulation of gonadotropin secretion in mice. Endocrinology 153:316-328

27. Coolen LM, Smith TG, Lehman MN, Hileman SM, Connors JM, Goodman RL. 2013 Arcuate KNDy neurons receive afferent projections from the retrochiasmatic area in the ewe. (Abstract)

28. Lehman MN, Durham DM, Jansen HT, Adrian B, Goodman RL 1996 Dopaminergic A14/A15 neurons are activated during estradiol negative feedback in anestrous, but not breeding season, ewes. Endocrinology 137:4443-4450

29. Thiery JC, Gayrard V, Le CS, Viguie C, Martin GB, Chemineau P, Malpaux B 1995 Dopaminergic control of LH secretion by the A15 nucleus in anoestrous ewes. J Reprod Fertil Suppl 49:285-296 


\section{Figure 1}
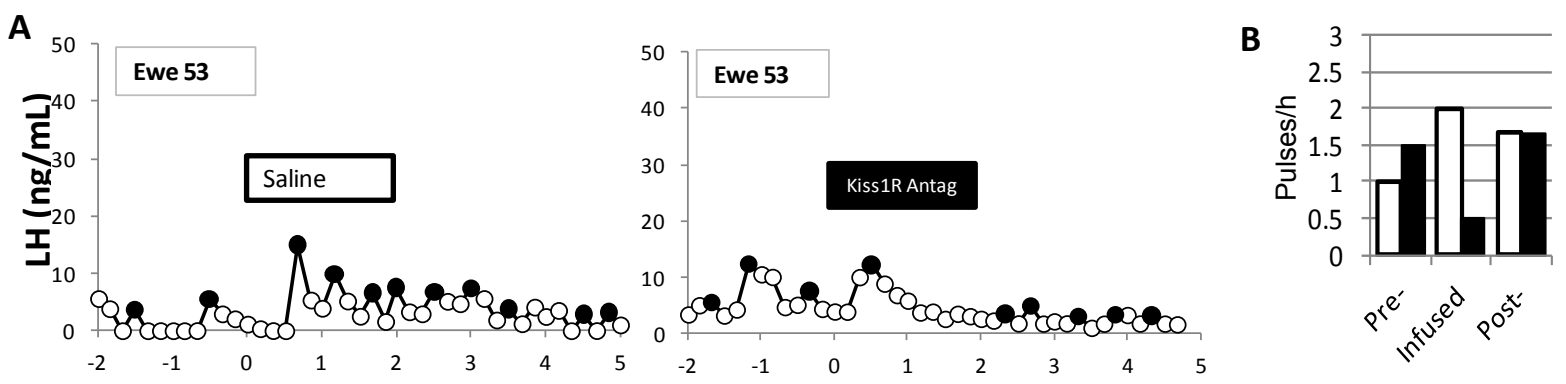

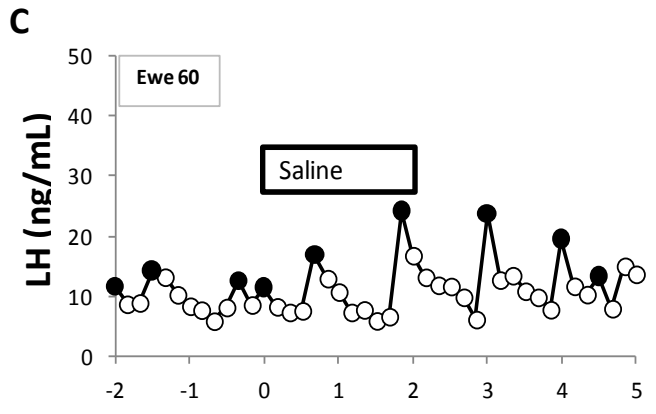

Time (h)
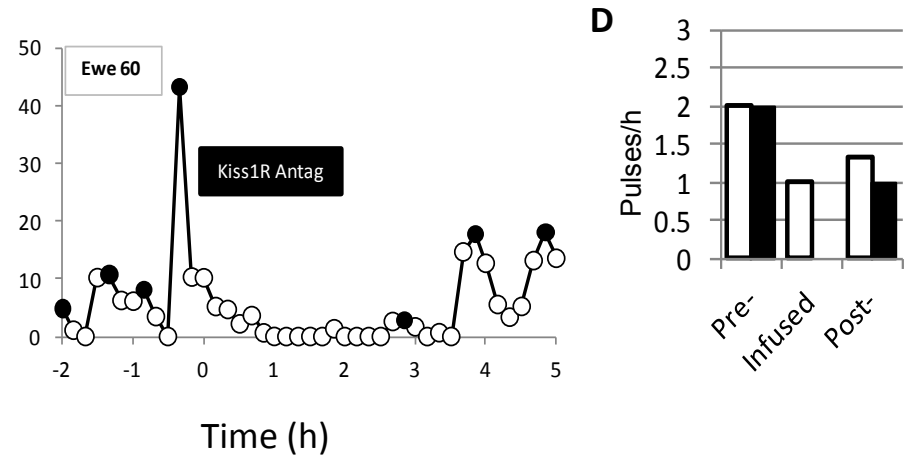

Figure 1. LH profiles from OVX ewes $(\mathrm{n}=2)$ given icv infusion of the Kiss1r antagonist (p234-pen) or saline, in a crossover experiment, to determine if the Kiss1r antagonist suppresses LH pulse frequency. Solid circles depict peaks of LH pulses. White bars depict saline treatment and black bars depict Kiss1r antagonist treatment. 


\section{Figure 2}
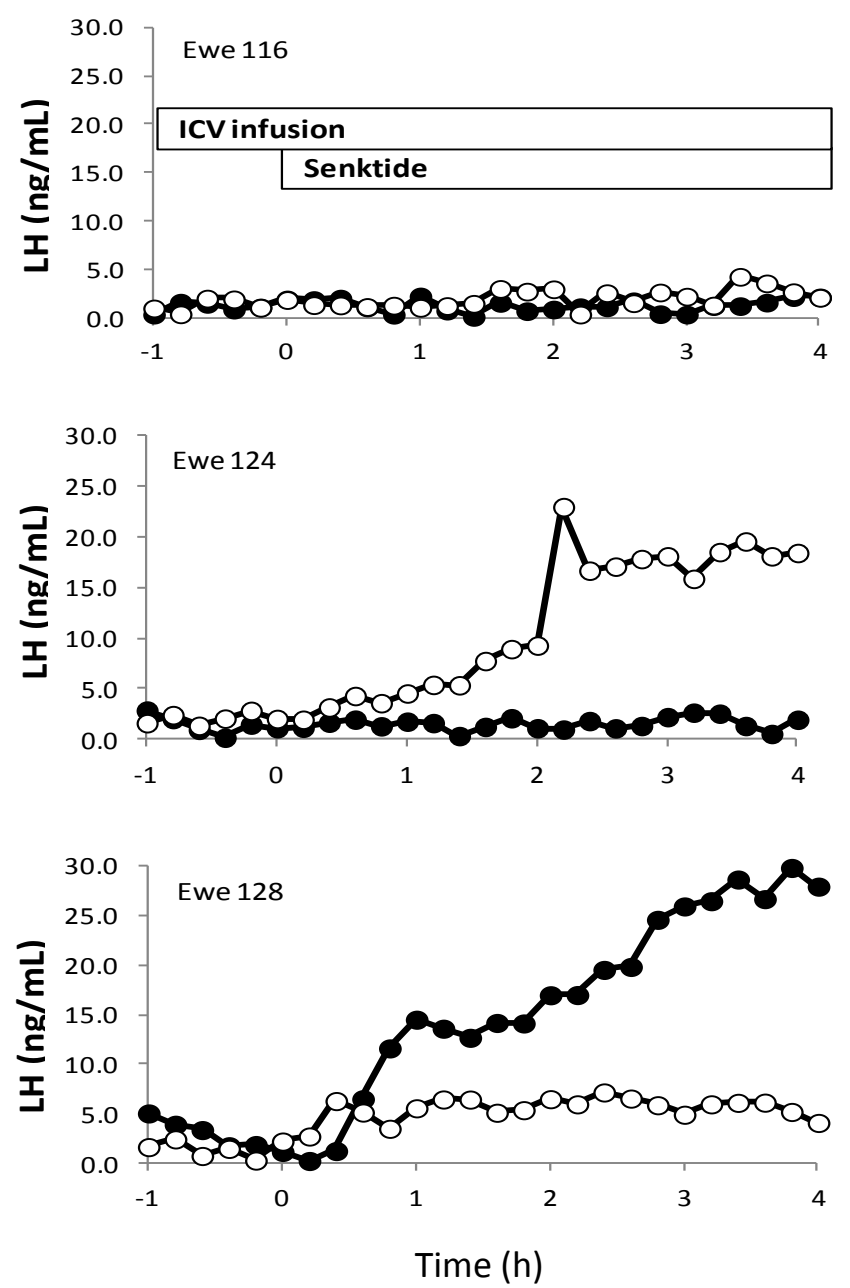

Figure 2. Representative LH profiles from ewes given icv infusion of the Kiss1r antagonist (p234-pen, solid circles) or saline (open circles) during RCh treatment with senktide microimplants. LH responses to senktide varied among animals (as shown). 


\section{Figure 3}
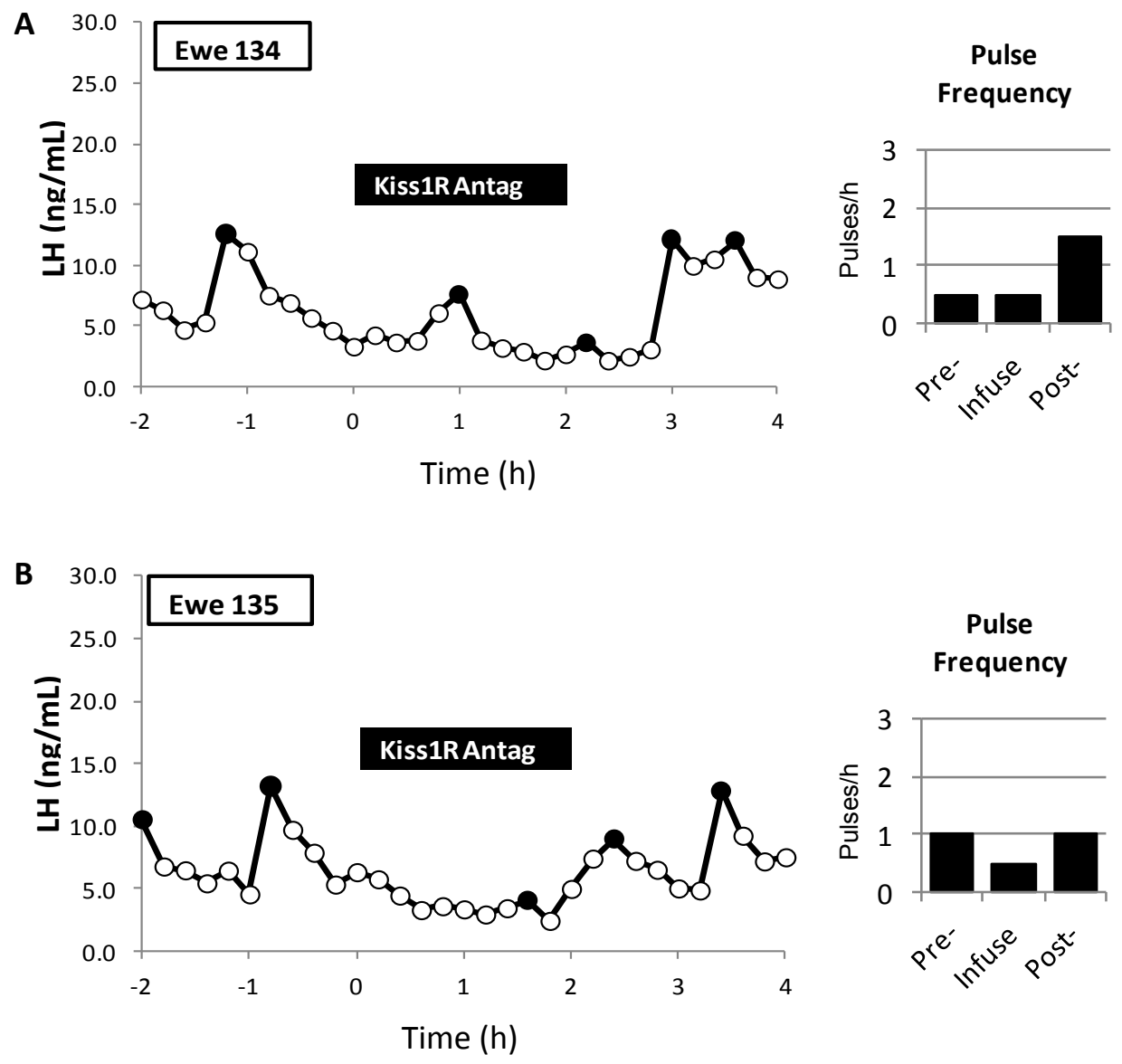

Figure 3. LH profiles from OVX ewes $(n=2)$ given icv infusion of the Kiss1r antagonist (p234-pen) as a follow-up to the Kiss1r antagonist/senktide microimplant experiment (Exp. 2, part 2) to assess efficacy of the antagonist. Solid circles depict peaks of LH pulses. 


\section{Figure 4}
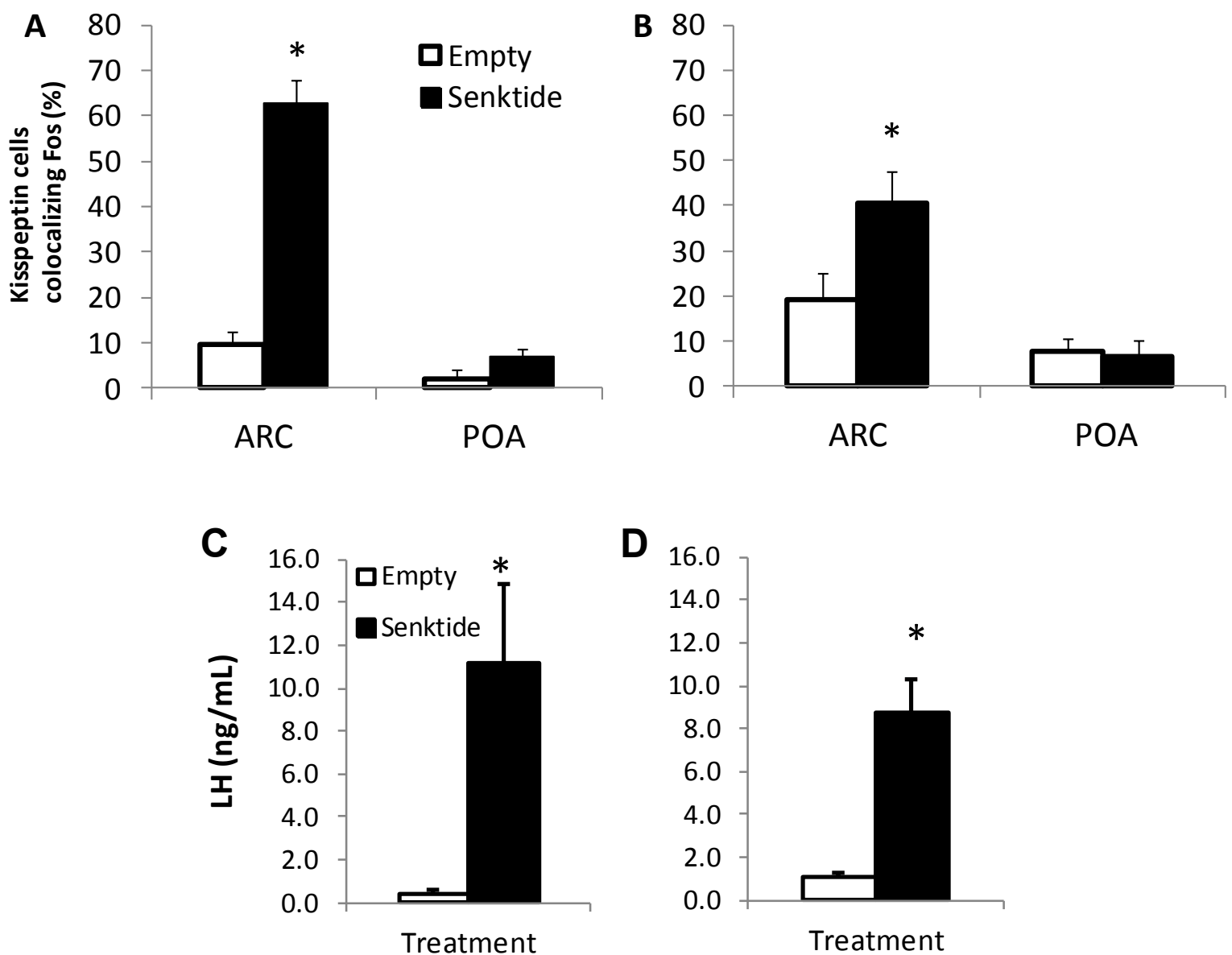

Figure 4. Kisspeptin cells in the ARC exhibit increased activation following senktide treatment. Mean percent colocalization with Fos is increased in ARC kisspeptin neurons, but not POA kisspeptin neurons, by senktide treatment in either the RCh (A) or the POA (B), in conjunction with an significant increase in LH secretion $(\mathrm{C}, \mathrm{RCh}$ and $\mathrm{D}, \mathrm{POA}) .{ }^{*}, \mathrm{P}<0.05$ compared to empty implants. 
CHAPTER 5

GENERAL DISCUSSION 


\section{THE ROLE OF NKB IN LH PULSE GENERATION}

Research findings to date on the role of kisspeptin and NKB largely agree that KNDy neurons play a key role in pulse generation in a variety of species. Based on the current model (Ch. 1, Fig. 1), NKB is thought to be responsible for initiation of each pulse, DYN acts to terminate the pulse, and kisspeptin serves as a stimulatory output to GnRH neurons. In line with this proposed role in the control of $\mathrm{GnRH}$ pulses, these neurons also appear to mediate the negative feedback actions of $\mathrm{E}_{2}$ on tonic $\mathrm{LH}$ secretion in rodents and sheep. My findings herein agree with these roles for ARC kisspeptin and NKB neurons in ewes. First, we confirmed that kisspeptin neurons in the ARC, but not in the POA, exhibit increased activation in the short- or long-term absence of $\mathrm{E}_{2}$, indicating that the activity of KNDy neurons is typically under $E_{2}$ negative feedback regulation and that activation of these ARC neurons is associated with the increase in pulsatile LH release observed following ovariectomy. Second, administration of the NK3R agonist, senktide, within the ARC stimulated LH secretion compared to control ewes. However, the amplitude of this increase in LH was lower that observed when senktide was given in the POA or RCh. The profile we observed following senktide treatment in the ARC revealed an increase in baseline values making it difficult to properly assess pulse frequency. Because NKB stimulates LH pulse frequency in OVX ewes (1), it is likely that ARC senktide treatment increased LH pulse frequency to a point that we could not observe a return to baseline between pulses.

In contrast to senktide, treatment with $\mathrm{NKB}$ in the $\mathrm{ARC}$ of follicular phase ewes did not significantly alter LH secretion. There are at least a few possible explanations for this difference in actions of these NK3R agonists. As mentioned in Ch. 3, one obvious explanation lies in the difference in the solubility of the two agonists, i.e. senktide is highly soluble in aqueous solutions while NKB is of low solubility. Thus, senktide may diffuse further from the implant site and reach a much larger number of NK3R-positive neurons than NKB. Also, senktide is highly specific for NK3R while NKB may act via multiple NKB receptors, as has been recently confirmed in mice (2). This is important in that interactions with multiple NKB receptor subtypes may alter the overall outcome of NKB administration if activation of either the NK1R or NK2R receptor subtype results in inhibition of GnRH secretion. Therefore, NKB 
would not stimulate a large increase in LH secretion as was observed with senktide treatment, which only acts through a "stimulatory" NK3R. There is some evidence that activation of NK2R or NK1R, by neuropeptide K (NPK) or substance P, respectively, can inhibit LH secretion in female rats $(3 ; 4)$. Stimulatory effects of these agonists have also been observed in rats (5) and in mice (2). However, these substances and their actions have not been investigated in ewes, and the location and distribution of NK1R and NK2R in the ovine hypothalamus is unknown. Finally, as noted above, ARC NKB microimplants stimulated LH pulse frequency in OVX ewes (6), an effect not seen in the follicular phase; one simple explanation for this discrepancy is that LH pulse frequency is considerably faster in the follicular phase, than in OVX, ewes (7) so further stimulation is not possible because it may already be close to maximal.

In summary, data gained in this portion of my dissertation, which focused on tonic LH secretion and $\mathrm{E}_{2}$ negative feedback, fit with the current model for the role of KNDy neurons, and specifically NKB, in LH pulse generation. However, the specific interactions of NKB or senktide with NKB receptor subtypes remain unclear. Further studies are warranted to assess 1) the location of NK1R and NK2R within the sheep hypothalamus and 2) whether activation of non-NK3 receptor subtypes yield inhibitory effects on LH secretion. Furthermore, in order to better assess whether senktide acts in the ARC to increase GnRH pulse frequency or GnRH secretion between pulses, the release of GnRH in response to ARC senktide should be analyzed.

Senktide treatment in the ARC produced a moderate increase in LH secretion, in which LH concentrations increased shortly after treatment and were maintained at around that same level for the remainder of the sampling period. During this time nadirs did not return to the pre-treatment baseline. We speculate that this may be indicative of increased pulse frequency, during which there is not sufficient time for LH concentrations to return to baseline between pulses due to the half-life of LH. Since GnRH has a shorter half-life than LH, GnRH pulse nadir may not be altered, allowing us to get a clearer view of pulse frequency alterations. 


\section{THE ROLE OF NKB IN THE LH SURGE}

One current model for the LH surge in ewes proposes a key role for the POA since kisspeptin neurons in that area show increased levels of activation during an $\mathrm{E}_{2}$-induced LH surge in ewes (8). However, earlier work indicates that $\mathrm{E}_{2}$-containing microimplants placed in the ovine $\mathrm{MBH}$, were sufficient to stimulate an LH surge, whereas $\mathrm{E}_{2}$ implants in the POA did not elicit a surge (9). Together, these data indicate that the initiation of the $\mathrm{LH}$ surge by $\mathrm{E}_{2}$ likely occurs in the $\mathrm{MBH}$ but that the POA kisspeptin neurons are also involved in the large increase in GnRH secretion. We have shown herein that both POA and ARC kisspeptin neurons exhibit increased activation (using Fos as an index; see Ch. 2) during an $\mathrm{E}_{2}$-induced LH surge, indicating that kisspeptin neurons in both areas are involved in the surge. These findings are in contrast to the finding by Hoffman et al (8) in which they saw no increase in activity in ARC kisspeptin neurons during the surge. One possible explanation for this discrepancy is that the ewes used in that study had chronic guide tubes traversing the ARC, aimed at the median eminence to measure GnRH, which may have disrupted the ARC kisspeptin network. Another possible difference is the use of different antibodies, which may have different sensitivities, for detection of Fos in these two studies. Despite this discrepancy, the results of two studies monitoring kisspeptin mRNA levels in ewes are consistent with our finding that both $\mathrm{ARC}$ and POA kisspeptin neurons are active during $\mathrm{E}_{2}$ positive feedback in ewes $(10 ; 11)$.

Since most NKB neurons in ewes are located within the ARC $(12 ; 13)$ and the vast majority of ARC NKB neurons coexpress kisspeptin (14) and are thus activated during the LH surge (Ch. 2), we hypothesized that NKB may also be involved in the LH surge. Furthermore, a previous study from our laboratory had shown that the NK3R agonist senktide stimulates LH secretion in a pattern resembling a surge (15). Studies herein have determined that senktide administered in either the RCh or the POA, but not the ARC, elicits surge-like LH secretion (Ch. 3), indicating that NK3R activation in these areas might be part of the LH surge mechanism. However, at this time, we cannot be certain that the secretion of LH in response to senktide actually represents true surge secretion. Senktide administration may be stimulating pulse frequency in such a way that pulses occur so close together that we no longer can 
discern individual pulses. Again, one way to examine this possibility would be to assess GnRH secretion following senktide treatment in the RCh and POA.

To more definitively determine whether NK3R in the RCh or POA were involved in the GnRH surge, we assessed the effect of blocking endogenous NKB action on NK3R in the RCh or POA during an $\mathrm{E}_{2}$-induced LH surge. In Ch. 3 we showed that the NK3R antagonist SB222200 in the RCh decreased the amplitude of the $\mathrm{E}_{2}$-induced LH surge by $42 \%$ on average while placement of the antagonist in the POA had no effect. Therefore we propose that only RCh NK3R activation is essential for the full preovulatory surge. Furthermore, we suggest that while the NKB-NK3R interaction helps drive LH secretion during the surge, it is likely not responsible for LH surge generation since the NK3R antagonist did not alter timing of the LH surge. This fits well with the finding that $\mathrm{E}_{2}$ implants in the MBH elicit an LH surge in ewes, while $\mathrm{E}_{2}$ treatment in the rostral hypothalamus does not (9), indicating that $\mathrm{E}_{2}$ in the $\mathrm{MBH}$ is likely responsible for surge initiation.

We acknowledge that based on these data, we cannot rule out the possibility that the NK3R-NKB interaction in the POA is important for full expression of the GnRH surge. Solubility of SB222200 in aqueous solutions is very low and NK3R in the POA are more widely scattered than those in the RCh (16). Thus, SB222200 treatment in the POA may not reach sufficient numbers of NK3R receptorexpressing neurons in this area to alter the surge. Therefore, the role of POA NK3R activation in the LH surge will require further investigation.

After determining that activation of NK3R-positive neurons in the RCh is essential to achieving the full LH surge, we next examined one possible pathway through which this activation alters LH secretion, namely via kisspeptin-containing neurons. It was previously shown that blocking Kiss 1r (via icv infusion of a Kiss1r antagonist) decreases LH surge amplitude by $\sim 50 \%$ in ewes (17). Since SB222200 microimplants in the RCh produced a decrease of similar magnitude, and other data suggests that the stimulatory action of NKB or senktide in the ARC on tonic LH secretion is mediated by kisspeptin signaling, we hypothesized that NK3R-positive neurons in the RCh act via kisspeptin to alter LH secretion. Herein we have shown that senktide treatment in the RCh increased kisspeptin/Fos 
colocalization in the ARC, but not in the POA, which is coincident with the surge-like secretion of LH. Together with the ICC data, these findings indicate that LH secretion induced by RCh NK3R activation may be kisspeptin-dependent, and it appears to be ARC, not POA, kisspeptin that is involved, based on our ICC data. In order to further test the possible involvement of the POA or ARC kisspeptin population in the senktide-induced LH response, we could potentially 'knockdown' one population at a time, for example using an anti-kisspeptin lenti-viral vector injected directly into the area of interest, prior to senktide experiments. This would determine whether either population of kisspeptin neurons is necessary for the senktide effects on LH secretion.

Finally, in collaboration with colleagues, we are completing tract tracing experiments to assess projections from the RCh in ewes. Preliminary findings indicate that RCh neurons project to KNDy neurons, revealing an anatomical pathway through which these interactions may directly occur (18). However, we do not yet know if these RCh neurons are NK3R-positive. One way to determine this is by injecting a retrograde tract tracer into the $\mathrm{ARC}$, and using dual ICC to determine if RCh neurons expressing the tract tracer also express NK3R.

In summary, the data obtained during my dissertation work warrant a modification to the existing model that kisspeptin alone is critical for GnRH surge generation in ewes. We postulate that a group of NK3R-positive neurons in the $\mathrm{RCh}$ receive input from NKB neurons originating in the ARC during the pre-surge phase. Once activated, the NK3R neurons can directly stimulate KNDy neurons to enhance LH surge amplitude (Fig. 1). Preliminary data indicates that NK3R-positive neurons in the RCh exhibit increased activation during the LH surge (unpublished data; Christina Merkley and Mike Lehman), supporting our hypothesis that these neurons are essential for full expression of the preovulatory LH surge. 


\section{Figure 1}

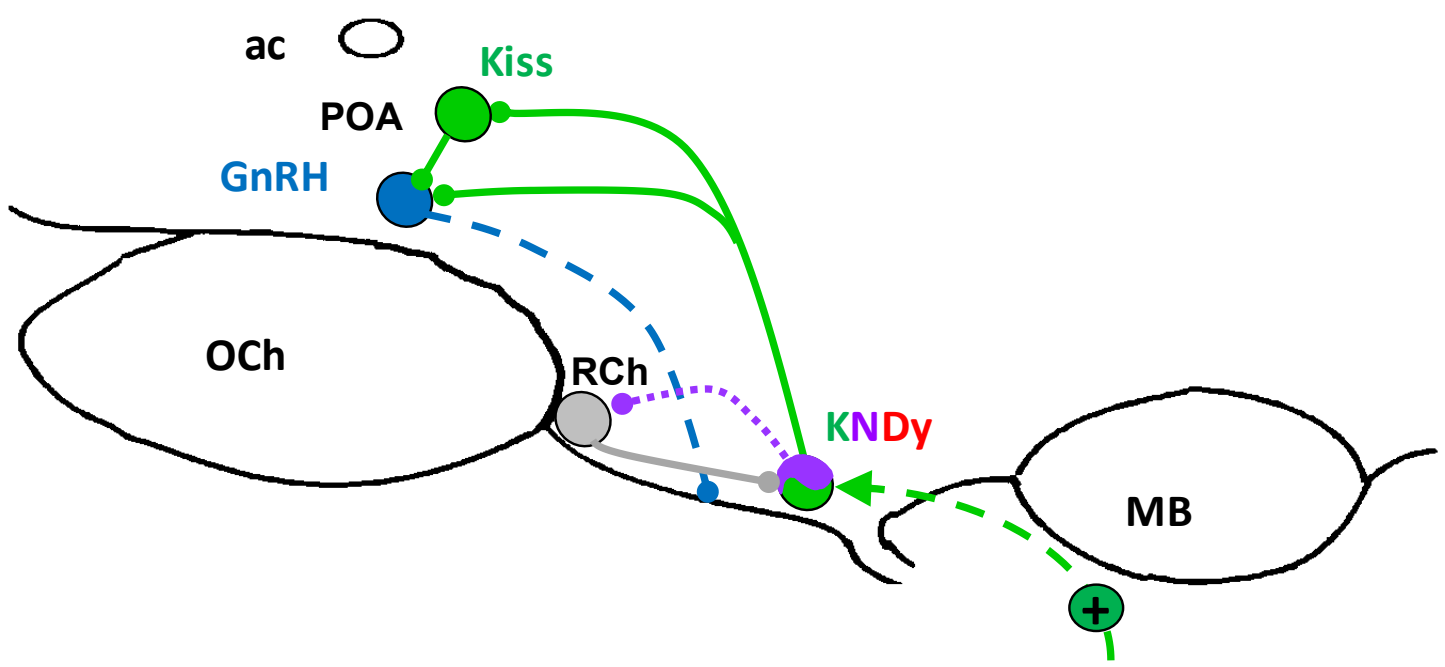

High $\mathrm{E}_{2}$

Figure 1: Newly proposed model of the GnRH/LH surge in ewes, showing the relationship of NK3R-positive RCh neurons (grey) to ARC KNDy neurons (green and purple). 
Of course, some unresolved questions remain. First, how do KNDy neurons in the ARC mediate both tonic and surge secretion of $\mathrm{GnRH} / \mathrm{LH}$ ? One aspect of this idea that must be reconciled is how the same population of neurons can mediate both negative and positive $\mathrm{E}_{2}$ feedback. Two possible explanations have been proposed: 1) two different subsets of KNDy neurons mediate the different actions of $E_{2}$ or 2) the same set of neurons responds differently to high or low concentrations of $E_{2}$, perhaps resulting in the initiation of different intracellular signaling mechanisms (19;20). Our data in Ch. 2 supports the latter explanation since $\sim 90 \%$ of KNDy neurons were activated following OVX and $\sim 50 \%$ were activated at the time of surge.

NKB may play a role in this differential regulation of LH secretion. For example, does NKB activate neurons in the RCh only during the surge? It is possible that NKB only reaches the RCh in significant concentrations during the surge or, in contrast, that NKB reaches the RCh at times other than during the LH surge, but that NK3R availability in the RCh is only high enough to respond during the late follicular phase. In order to assess the possible change in receptor availability, one could look at NK3R expression and/or receptor internalization in the RCh during surge versus non-surge time points.

Furthermore, it is possible that output from the NK3R-positive cells in the RCh is reduced during non-surge times such that the NKB signal reaches the RCh NK3R, but output from those neurons is inhibited. Since the identity of the RCh neurons that project to KNDy neurons remains unknown, a first step in testing this hypothesis would be to determine the neuronal phenotype(s) of NK3R cells in this area.

Another way to determine if the LH secretion in response to senktide is part of the mechanism driving the surge is to complete the same type of experiments in male counterparts ( $\mathrm{E}_{2}$-treated wethers), because the $\mathrm{GnRH} / \mathrm{LH}$ surge is sexually differentiated in sheep, with males or androgen-treated females not exhibiting surges $(18 ; 21)$. Therefore, if you administer senktide to males and see the same surge-like LH profile, it would indicate that it is actually not a surge but rather high frequency LH secretion, as mentioned above. On the other hand, if the males do not exhibit a similar LH secretion profile in response to senktide, it would indicate that senktide stimulates a true LH surge in females. 
Dynorphin is the third neuropeptide of the KNDy moniker. Thus, a possible role for DYN must also be considered for the surge-related actions of NKB. DYN is clearly involved in mediating the inhibitory effects of progesterone on GnRH secretion. If DYN release or interaction with its receptors is decreased during the surge (thus turning off a "brake" on LH secretion), this could allow NKB levels to reach a threshold for activation of RCh NK3R-positive neurons. However, it has previously been shown that $\mu$-receptors, but not $\kappa$-receptors, are potentially involved in inhibition of the LH surge (22-26), and furthermore, EOP antagonists do not advance the surge in ewes $(22 ; 23 ; 27)$. Therefore it is unlikely that DYN is involved in surge regulation.

The data herein has revealed a previously unknown portion of the GnRH/LH surge mechanism in ewes involving NK3R-positive neurons located in the RCh. However, many of the pathways responsible for the stimulatory actions of NK3R activation in this area on GnRH release remain to be determined. Hopefully, the identification of these mechanisms will become the focus of many studies to follow in the future. 


\section{Reference List}

1. Goodman RL, Hileman SM, Nestor CC, Porter KL, Connors JM, Hardy SL, Millar RP, Cernea M, Coolen LM, Lehman MN 2013 Kisspeptin, neurokinin B, and dynorphin act in the arcuate nucleus to control activity of the GnRH pulse generator in ewes. Endocrinology

2. de Croft S, Boehm U, Herbison AE 2013 Neurokinin B activates arcuate kisspeptin neurons through multiple tachykinin receptors in the male mouse. Endocrinology

3. Duval P, Lenoir V, Kerdelhue B 1998 The in vitro effect of substance P on the GnRH-induced LH release depends on the steroidal environment and is reverted by a NK1 receptor antagonist (RP 67580 ) in the cycling female rat. Neuropeptides 32:97-101

4. Sahu A, Kalra SP 1992 Effects of tachykinins on luteinizing hormone release in female rats: potent inhibitory action of neuropeptide K. Endocrinology 130:1571-1577

5. Hatae T, Kawano H, Karpitskiy V, Krause JE, Masuko S 2001 Arginine-vasopressin neurons in the rat hypothalamus produce neurokinin B and co-express the tachykinin NK-3 receptor and angiotensin II type 1 receptor. Arch Histol Cytol 64:37-44

6. Goodman RL, Hileman SM, Nestor CC, Porter KL, Connors JM, Hardy SL, Millar RP, Cernea M, Coolen LM, Lehman MN 2013 Kisspeptin, neurokinin B, and dynorphin act in the arcuate nucleus to control activity of the GnRH pulse generator in ewes. Endocrinology

7. Karsch FJ, Foster DL, Bittman EL, Goodman RL 1983 A Role for Estradiol in Enhancing Luteinizing-Hormone Pulse Frequency During the Follicular Phase of the Estrous-Cycle of Sheep. Endocrinology 113:1333-1339

8. Hoffman GE, Le WW, Franceschini I, Caraty A, Advis JP 2011 Expression of fos and in vivo median eminence release of LHRH identifies an active role for preoptic area kisspeptin neurons in synchronized surges of LH and LHRH in the ewe. Endocrinology 152:214-222

9. Caraty A, Fabre-Nys C, Delaleu B, Locatelli A, Bruneau G, Karsch FJ, Herbison A 1998 Evidence that the mediobasal hypothalamus is the primary site of action of estradiol in inducing the preovulatory gonadotropin releasing hormone surge in the ewe. Endocrinology 139:1752-1760

10. Estrada KM, Clay CM, Pompolo S, Smith JT, Clarke IJ 2006 Elevated KiSS-1 expression in the arcuate nucleus prior to the cyclic preovulatory gonadotrophin-releasing hormone/lutenising hormone surge in the ewe suggests a stimulatory role for kisspeptin in oestrogen-positive feedback. Journal of Neuroendocrinology 18:806-809 
11. Smith JT, Li Q, Pereira A, Clarke IJ 2009 Kisspeptin neurons in the ovine arcuate nucleus and preoptic area are involved in the preovulatory luteinizing hormone surge. Endocrinology 150:55305538

12. Foradori CD, Amstalden M, Goodman RL, Lehman MN 2006 Colocalisation of dynorphin a and neurokinin B immunoreactivity in the arcuate nucleus and median eminence of the sheep. Journal of Neuroendocrinology 18:534-541

13. Goubillon ML, Forsdike RA, Robinson JE, Ciofi P, Caraty A, Herbison AE 2000 Identification of neurokinin B-expressing neurons as an highly estrogen-receptive, sexually dimorphic cell group in the ovine arcuate nucleus. Endocrinology 141:4218-4225

14. Goodman RL, Lehman MN, Smith JT, Coolen LM, de Oliveira CV, Jafarzadehshirazi MR, Pereira A, Iqbal J, Caraty A, Ciofi P, Clarke IJ 2007 Kisspeptin neurons in the arcuate nucleus of the ewe express both dynorphin A and neurokinin B. Endocrinology 148:5752-5760

15. Billings HJ, Connors JM, Altman SN, Hileman SM, Holaskova I, Lehman MN, McManus CJ, Nestor CC, Jacobs BH, Goodman RL 2010 Neurokinin B acts via the neurokinin-3 receptor in the retrochiasmatic area to stimulate luteinizing hormone secretion in sheep. Endocrinology $151: 3836-3846$

16. Amstalden M, Coolen LM, Hemmerle AM, Billings HJ, Connors JM, Goodman RL, Lehman MN 2010 Neurokinin 3 receptor immunoreactivity in the septal region, preoptic area and hypothalamus of the female sheep: colocalisation in neurokinin B cells of the arcuate nucleus but not in gonadotrophin-releasing hormone neurones. J Neuroendocrinol 22:1-12

17. Smith JT, Li Q, Yap KS, Shahab M, Roseweir AK, Millar RP, Clarke IJ 2011 Kisspeptin is essential for the full preovulatory LH surge and stimulates GnRH release from the isolated ovine median eminence. Endocrinology 152:1001-1012

18. Coolen LM, Smith TG, Lehman MN, Hileman SM, Connors JM, Goodman RL, Arcuate KNDy neurons receive afferent projections from the retrochiasmatic area in the ewe. (Abstract)

19. Glidewell-Kenney C, Hurley LA, Pfaff L, Weiss J, Levine JE, Jameson JL 2007 Nonclassical estrogen receptor alpha signaling mediates negative feedback in the female mouse reproductive axis. Proc Natl Acad Sci U S A 104:8173-8177

20. Lehman MN, Coolen LM, Goodman RL 2010 Minireview: Kisspeptin/Neurokinin B/Dynorphin (KNDy) Cells of the Arcuate Nucleus: A Central Node in the Control of Gonadotropin-Releasing Hormone Secretion. Endocrinology 151:3479-3489 
21. Foster DL, Padmanabhan V, Wood RI, Robinson JE 2002 Sexual differentiation of the neuroendocrine control of gonadotrophin secretion: concepts derived from sheep models. Reproduction Supplement 59:83-99

22. Conover CD, Kuljis RO, Rabii J, Advis JP 1993 Beta-endorphin regulation of luteinizing hormone-releasing hormone release at the median eminence in ewes: immunocytochemical and physiological evidence. Neuroendocrinology 57:1182-1195

23. Currie WD, Joseph IB, Rawlings NC 1991 Morphine, naloxone and the gonadotrophin surge in ewes. J Reprod Fertil 92:407-414

24. Domanski E, Chomicka LK, Ostrowska A, Gajewska A, Mateusiak K 1991 Release of luteinizing hormone-releasing hormone, beta-endorphin and noradrenaline by the nucleus infundibularis/median eminence during periovulatory period in the sheep. Neuroendocrinology 54:151-158

25. Pillon D, Caraty A, Fabre-Nys C, Bruneau G 2003 Short-term effect of oestradiol on neurokinin B mRNA expression in the infundibular nucleus of ewes. J Neuroendocrinol 15:749-753

26. Walsh JP, Clarke IJ 1996 Effects of central administration of highly selective opioid mu-, deltaand kappa-receptor agonists on plasma luteinizing hormone (LH), prolactin, and the estrogeninduced LH surge in ovariectomized ewes. Endocrinology 137:3640-3648

27. Horton RJ, Clarke IJ 1988 Lack of an effect of morphine or naloxone on the oestrogen-induced LH surge in anoestrous ewes. J Endocrinol 119:89-93 


\title{
CURRICULUM VITAE
}

\section{Katrina L. Porter}

West Virginia University

Department of Physiology and Pharmacology

P.O. Box 9229

Morgantown, WV 26506

H: 304-692-0931

$W: 304-293-1505$

E-mail:ksites@mix.wvu.edu

\section{EDUCATION}

2013

Ph.D. Biomedical Sciences

West Virginia University

2006

B.S. Exercise Physiology

West Virginia University

Doctoral Advisor: Robert L. Goodman, Ph.D.

Doctoral Dissertation: The Role of Neurokinin B in the Regulation of the Preovulatory LH

\author{
Surge in Ewes
}

\section{RESEARCH EXPERIENCE}

2010-

Research Assistant, Laboratory of Dr. Robert L. Goodman, Ph.D.

- Performed immunocytochemistry and immunofluorescence on hypothalamic tissue sections to assess neuronal activation (including but not limited to kisspeptin, Fos, NKB)

- Venipuncture for blood collection (ovine)

- Insertion of jugular catheters (ovine)

- Neurosurgery: stereotaxic insertion of chronic guide tubes in specific brain areas (ARC, POA, PVN, RCh

- Bilateral ovariectomy surgery

- Tissue sectioning: hypothalamic tissue blocks using a freezing microtome

- Microinjections or microinfusions of neuropeptides or receptor agonists or antagonists into the third or lateral cerebroventricle (ovine) 
- Conducted intravital microscopy of the spinotrapezius muscle in rats to assess microvascular reactivity

- Performed isolated vessel experiments on skeletal muscle arterioles

\section{PUBLICATIONS}

Goodman RL, SM Hileman, CC Nestor, KL Porter, JM Connors, SL Hardy, RP Millar, M Cernea, LM Coolen, MN Lehman. 2013 Kisspeptin, neurokinin B, and dynorphin act in the arcuate nucleus to control activity of the GnRH pulse generator in ewes. Endocrinology 154(11):4259-69.

Merkley CM*, KL Porter*, LM Coolen, SM Hileman, HJ Billings, S Drews, RL Goodman, MN Lehman. (*Shared first authorship) 2012 KNDy (Kisspeptin/Neurokinin B/Dynorphin) Neurons are Activated During Both Pulsatile and Surge Secretion of LH in the Ewe. Endocrinology 153(11); 5406-14.

\section{PAPERS IN PREPARATION}

Porter KL, SM Hileman, SL Hardy, CC Nestor, RL Goodman (submitted) Neurokinin-3 Receptor Activation in the Retrochiasmatic Area is Essential for the Full Preovulatory LH Surge in Ewes

Porter KL, SM Hileman, RL Goodman (in preparation) Senktide Stimulates LH Secretion via Arcuate Kisspeptin Neurons in Ewes

\section{ABSTRACTS}

KL Porter, SM Hileman, SL Hardy, RL Goodman. 2013 Neurokinin B signaling in the retrochiasmatic area is essential for the full preovulatory LH surge in ewes. Annual meeting of the Society for Neuroscience (San Diego, CA)

SM Hileman, Meadows LJ, Porter KL, Coolen LM, Fergani C, Rempel LA, Cushman RA, Oliver WT, Wright EC, Miles JR, Lents CA. 2013 Effect of progesterone on kisspeptin and neurokinin B cell numbers in the arcuate nucleus of the female pig. Annual meeting of the Society for Neuroscience (San Diego, CA)

RL Goodman, KL Porter, JM Connors, SM Hileman. 2013 Neurokinin B (NKB) and the NKB receptor agonist, senktide, act in the ovine arcuate nucleus to produce different patterns of LH release. Annual meeting of the Endocrine Society (San Francisco, CA)

KL Porter, SM Hileman, SL Hardy, RL Goodman. 2013 Senktide administration in the retrochiasmatic area and preoptic area stimulates surge-like LH secretion in ewes. Annual meeting of the Endocrine Society (San Francisco, CA) 
Goodman RL, KL Porter, JM Connors, CC Nestor, MN Lehman, SM Hileman. 2012 Evidence that dynorphin, but not glutamate or $\mathrm{GnRH}$, acts in the arcuate nucleus of the ewe to control episodic GnRH release. Annual meeting of the Society for Neuroscience (New Orleans, LA)

Porter, KL, SM Hileman, S Drews, RL Goodman. 2011 Arcuate kisspeptin neurons are rapidly activated by removal of estrogen negative feedback in anestrous ewes. Annual meeting for the Society for Neuroscience (Washington, DC)

Porter, KL, TR Nurkiewicz. 2010 Diesel exhaust particle exposure augments arteriolar mechanotransduction. The Toxicologist 114(1):368, 1730. Annual meeting for the Society of Toxicology (Salt Lake City, UT)

Porter, KL, TR Nurkiewicz. 2010 Arteriolar Mechanotransduction is Altered by Diesel Exhaust Particle Exposure. NIEHS-EPA Symposium on Air Pollution. (Seattle, WA)

Sites, KL, AG Goodwill, JC Frisbee, TR Nurkiewicz. 2009 Diesel exhaust exposure alters microvascular blood flow and wall shear rate. The Toxicologist, March 108 (1-5), 200. Annual meeting for the Society of Toxicology(Baltimore, MD)

\section{TEACHING EXPERIENCE}

West Virginia University, PSIO/NBAN 107, Intro. to Human Anatomy \& Physiology

Guest Lecturer, Cardiovascular and Lymphatic Systems (7 hours)

Oct 2011- Pierpont Community and Technical College, Fairmont, WV

May 2012 Adjunct Professor, Anatomy and Physiology

Taught Anat. \& Phys. lectures and laboratories for undergraduate nursing, veterinary technician, and respiratory therapy students; material included all topics as covered by Hole's Essentials of Anatomy and Physiology textbook $\left(10^{\text {th }}\right.$ edition). Duties included: lecturing, preparing and teaching labs, writing exams/quizzes, scoring exams/quizzes.

2011- West Virginia University, Undergraduate and Graduate Physiology Courses

2013 Tutor

2011 West Virginia University, PSIO 241, Physiology

Guest Lecturer, Blood (2 hours)

\section{RESEARCH SUPPORT}

2009- $\quad$ NIH Cardiovascular and Pulmonary Disease Training Grant

2010

NHLBI-T32 Pre-Doctoral training grant

Principal Investigator: S.J. Mustafa, West Virginia University 